\title{
DIVERSITY AND ABUNDANCE OF MEDICINAL \\ PLANTS AMONG DIFFERENT FOREST-USE TYPES OF THE PAKISTANI HIMALAYA
}

\author{
Muhammad Adnan \\ (Born in Charsadda, Khyber Pakhtunkhwa, Pakistan)
}

A Dissertation Submitted in Partial Fulfillment of the Requirements for the Academic Degree of

Doctor of Philosophy (PhD) of the Faculty of Forest Sciences and Forest Ecology of the Georg-August-University of Göttingen

Supervisor

Prof. Dr. Dirk Hölscher

Göttingen, November 2011 
Reviewers

Prof. Dr. Dirk Hölscher

Prof. Dr. Christian Ammer

\section{Examiners}

Prof. Dr. Dirk Hölscher

Prof. Dr. Christian Ammer

Prof. Dr. Erwin Bergmeier 


\section{SUMMARY}

Medicinal plants collected in the Himalayan forests are receiving increasing attention at the international level for a number of reasons and they play an important role in securing rural livelihoods. However, these forests have been heavily transformed over the years by logging, grazing and agriculture. This thesis examines the extent to which the diversity and abundance of medicinal plants are affected between forest-use types as a result of such transformations.

In northwestern Pakistan we studied old-growth forest, degraded forests (forests degraded by logging, derived woodland, agroforest and degraded sites) and restored forests (re-growth forests and reforestation sites). An approximate map was initially established covering an area of $90 \mathrm{~km}^{2}$ of the studied forest-use types and fifteen and five plots were allocated to five and two forest-use types respectively at altitudes ranging from $2,200 \mathrm{~m}$ to $2,400 \mathrm{~m}$ asl. The abundance and diversity of medicinal plants were then assessed therein.

Of the fifty-nine medicinal plant species (herbs and ferns) studied, old-growth forest contained the highest number thereof with fifty-five species, followed by re-growth forest with forty-nine species and finally, forest degraded by logging with only forty species. In terms of local use, all these species are employed to cure various diseases (intestinal, stomach etc.), and most of them have a relatively high market value. Species such as Aconitum heterophyllum and Coptis tecta are endemic to the Himalayan region and were found to occur exclusively in old-growth forest. The species composition and abundance in degraded forests differed markedly from that of oldgrowth forest, with all the degraded forest types having much lower medicinal plant densities and diversities. In addition, medicinal plant density correlated negatively with tree canopy cover in degraded forests, which indicates that species adapted to open conditions dominate in disturbed landscapes.

Re-growth forest was somewhat similar to old-growth forest with densities of Bergenia ciliata, Viola canescens and Valeriana jatamansi being highest in old-growth forest and second highest in re-growth forest, which is most probably due to the species adaptation to the deep shade conditions provided by the high tree basal area and tree canopy cover under these forest-use 
types. Reforestation sites had a higher diversity of medicinal plants across the forest-use types, which may be due to the higher tree diversity under this forest-use type. Both re-growth forest and reforestation sites support the recovery of medicinal plant species such as Paeonia emodi and Podophyllum emodi, which are absent from most of the studied degraded forests and are important to the livelihoods of local people. Moreover, shade adapted medicinal plants can recover strongly under forest re-growth in comparison to reforestation sites, while for sunadapted or partial shade-adapted species the opposite holds true.

In conclusion, a high variation in the abundance and diversity of medicinal plants was found across the studied forest-use types. Old-growth forest is highly diverse and abundant in medicinal plants and is important as a refuge for vulnerable endemics. All forms of degraded forests have the lowest diversity of relatively common medicinal plants, which depends on the type of forest degradation. Forest re-growth and reforestation can facilitate the recovery of medicinal plants, including more economically valuable species that support local livelihoods, which in turn promotes ecological restoration and can pave the way forward to forest expansion in the region. 
TABLE OF CONTENTS

Summary

1 General Introduction 1

1.1 Medicinal plants collected in the forests 3

1.2 Medicinal plants under forest transformation 5

$\begin{array}{ll}1.3 \text { Study objectives and hypotheses } & 7\end{array}$

1.3.1 Objectives

1.3.2 Hypotheses $\quad 8$

$\begin{array}{ll}1.4 \text { Study area } & 8\end{array}$

1.4.1 Location, area and demography $\quad 8$

1.4.2 Forest administration and management 9

1.4.2.1 Guzara forests 9

$\begin{array}{ll}\text { 1.4.2.2 Reserve forests } & 10\end{array}$

1.4.3 Land use, agriculture and livestock 10

1.4.4 Soil and geology 11

1.4.5 Fauna 11

$\begin{array}{ll}1.4 .6 \text { Flora } & 11\end{array}$

1.4.7 Major conservation issues 12

1.4.7.1 Land tenure system 12

1.4.7.2 Grazing and fodder collection $\quad 13$

1.4.7.3 Fuel-wood and timber requirements 14

1.4.7.4 Impact of tourism 14

1.4.7.5 Over and improper harvesting of medicinal plants $\quad 14$

$\begin{array}{ll}\text { 1.4.8 Opportunity for research } & 15\end{array}$

$\begin{array}{ll}1.5 \text { Study design } & 15\end{array}$

1.5.1 Forest-use types studied 15

1.5.2 Study sites, plot selection and plot design 20

$\begin{array}{ll}1.6 \text { References } & 21\end{array}$ 
2 Diversity of medicinal plants among different forest-use types of the

Pakistani Himalaya

2.1 Abstract

2.2 Introduction

$\begin{array}{ll}2.3 \text { Materials and Methods } & 31\end{array}$

2.3.1 Study area $\quad 31$

2.3.2 Forest-use types and plot selection 32

2.3.3 Medicinal plants and uses $\quad 33$

2.3.4 Forest tree inventory and medicinal plants assessment 34

2.3.5 Statistical analysis $\quad 35$

$\begin{array}{ll}2.4 \text { Results } & 36\end{array}$

2.4.1 Comparison of medicinal plants diversity and abundance $\quad 36$ as a whole between forest-use types

2.4.2 Relationship between tree stand structure and medicinal plants $\quad 38$

2.5 Discussion 39

2.6 Acknowledgement 44

2.7 References 44

3 Medicinal plants in old-growth, degraded and re-growth forests of NW Pakistan 51

3.1 Abstract 53

3.2 Introduction $\quad 54$

3.3 Materials and Methods $\quad 56$

3.3.1 Study area $\quad 56$

3.3.2 Forest administration history and use $\quad 56$

3.3.3 Forest-use types studied $\quad 57$

3.3.4 Study sites and plot selection $\quad 59$

$\begin{array}{ll}\text { 3.3.5 Medicinal plants } & 60\end{array}$

3.3.6 Tree inventory and medicinal plant assessment $\quad 60$

3.3.7 Statistical analysis $\quad 64$

3.4 Results $\quad 64$

3.4.1 Stand structure and trees $\quad 64$ 
3.4.3 Relationship between tree stand structure and medicinal plants $\quad 66$

3.5 Discussion

3.6 Acknowledgement

4 Medicinal plant abundance in degraded and reforested sites in northwest Pakistan

4.2 Introduction

4.3 Materials and Methods

4.3.1 Study area $\quad 85$

4.3.2 Study sites and medicinal plants $\quad 86$

4.3.3 Tree inventory and medicinal plant assessment $\quad 89$

$\begin{array}{ll}\text { 4.3.4 Statistical analysis } & 90\end{array}$

$\begin{array}{ll}4.4 \text { Results } & 91\end{array}$

4.4.1 Forest stand structure $\quad 91$

4.4.2 Performance of medicinal plants on two land use types 91

$\begin{array}{ll}4.5 \text { Discussion } & 92\end{array}$

$\begin{array}{ll}4.6 \text { Acknowledgement } & 96\end{array}$

$\begin{array}{ll}4.7 \text { References } & 97\end{array}$

5 Synthesis 101

5.1 Medicinal plants under old-growth forest 103

$\begin{array}{ll}\text { 5.2 Medicinal plants under degraded forests } & 104\end{array}$

5.3 Forest restoration "an opportunity for the recovery of medicinal plants $\quad 106$

$\begin{array}{ll}5.4 \text { References } & 108\end{array}$

Acknowledgements $\quad$ xi

Declaration of originality and certificate of ownership xiii

Curriculum Vitae $\quad$ XV 


\section{LIST OF FIGURES}

Figure 1.1 A conceptual diagram of change in the tree canopy cover and 7 abundance of medicinal plants due to forest degradation and forest restoration.

Figure 1.2 Old-growth forest.

Figure 1.3 Forest degraded by logging.

Figure 1.4 Derived woodland.

Figure 1.5 Agroforest.

Figure 1.6 Degraded sites.

Figure 1.7 Reforestation sites.

Figure 1.8 Re-growth forest.

Figure 1.9 Establishment of inventory plot and taking hemispherical photograph

Figure 1.10 Medicinal plants collectors

Figure 1.11 Bergenia ciliata (Haw.) Sternb.

Figure 1.12 Valeriana jatamansi Wall.

Figure 1.13 Paeonia emodi Wall. ex Royle.

Figure 2.1 Map of the study area, forest-use types and plot design.

Figure 2.2 Similarity of forest-use types to old-growth forest for medicinal 37 plants.

Figure 2.3 Detrended correspondence analysis (DCA) for the response of medicinal plant species densities to tree canopy cover in three forestuse types. 
Figure 3.1 Map of the study area, forest-use types and plot design.

Figure 3.2 Similarity of forest-use types to old-growth forest for trees (A) and 66 medicinal plants $(\mathrm{B})$.

Figure 3.3 Detrended correspondence analysis (DCA) for the response of 70 medicinal plant species densities to tree canopy cover and basal area on five forest-use types.

Figure 4.1 Map of the study area and plot design.

Figure 4.2 Species specific frequencies, densities and cover percentages of 93 studied medicinal plants on reforested and degraded sites.

Figure 4.3 Detrended Correspondence Analysis (DCA) for the response of 94 individual medicinal plant densities to tree basal area on reforested sites.

Figure 5.1 A diagram of changes in the tree canopy cover among seven forest- 107 use types and the corresponding changes in the abundance of medicinal plants (Plantago lanceolata and Viola canescens). 


\section{LIST OF TABLES}

Table 2.1 General attributes and tree stand structural characteristics of three forest- 34 use types.

Table 2.2 Overall diversity and density of medicinal plants in old-growth forest, 36 forest degraded by logging and re-growth forest.

Table 2.3 Species indicator values of medicinal plant species under each forest-use 38 type.

Table 2.4 Spearman correlation between medicinal plant variables and tree stand 39 structural variables under each forest-use type.

Table 3.1 General attributes of the five studied forest-use types in NW Pakistan and 61 information on the 15 plots per forest-use type.

Table 3.2 Target medicinal plant species (all herbs).

Table 3.3 Tree and stand structural characteristics of five forest-use types.

Table 3.4 Variation of studied medicinal plants on the whole between five forest-use types.

Table 3.5 Species specific densities of studied medicinal plants on five forest-use 68 types.

Table 3.6 Local market value of medicinal plants under five forest-use types.

Table 3.7 Spearman correlation between medicinal plants densities with the basal 69 area of trees under individual forest-use type $(\mathrm{n}=15)$ and across forest-use types $(\mathrm{n}=75)$.

Table 4.1 Target medicinal plant species (herbs) and their uses.

Table 4.2 Tree and stand structural characteristics of reforested and degraded sites. $\quad 90$

Table 4.3 Variation of studied medicinal plants on the whole between reforested and 91 degraded sites.

Table 5.1 Variation in tree and stand structural characteristics and medicinal plants 105 among seven forest-use types.

Appendix Medicinal plants (herbs and ferns). 


\section{Chapter 1}

GENERAL INTRODUCTION
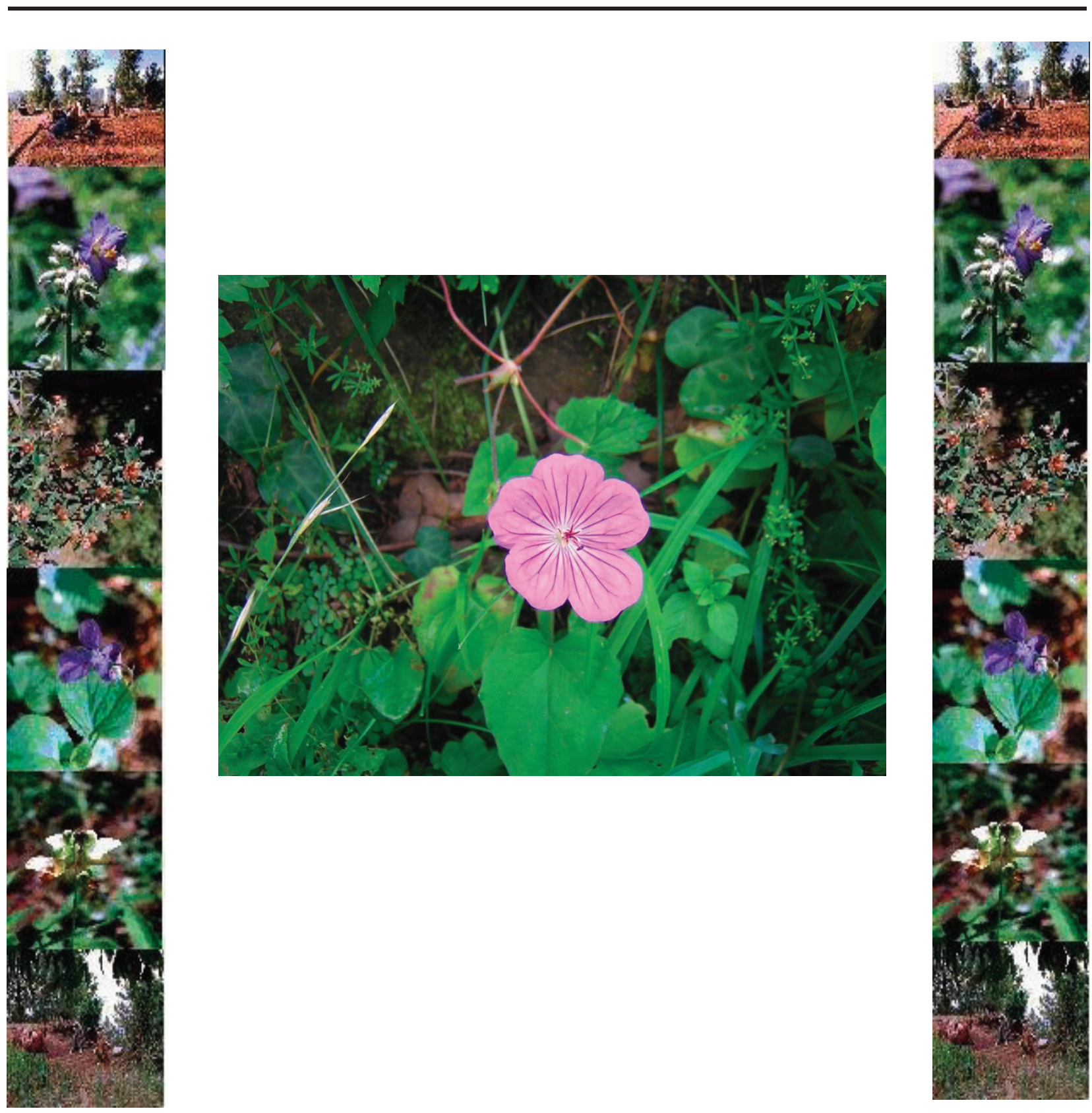
Medicinal plants are those that are commonly used in treating and preventing specific ailments and disease, and that are generally considered to play a beneficial role in health care (Srivastava, Lambert and Vietmeyer, 1996) 


\subsection{MEDICINAL PLANTS COLLECTED IN THE FORESTS}

Medicinal plants have been used for millennia in virtually all cultures and serve both as a source of income and a source of affordable healthcare (World Bank, 1997). Worldwide, about 53,000 plant species are used for medicinal purposes (Hamilton, 2004). The world market for traditional medicine in 2008 was calculated to be worth US \$83 billion (WHO, 2011). Traditional and folkloric medicines bequeathed through generations are rich in domestic recipes and communal practice and the use of traditional medicines and medicinal plants has been widely observed in most developing countries (Shinwari, 2010). The World Health Organization estimates that 70$95 \%$ of people living in developing countries rely chiefly on medicinal plants for their primary healthcare needs (WHO, 2011) and that their sale accounts for $15-30 \%$ of the total income of poorer households (Hamilton, 2004). However, an estimated 10,000 medicinal plants are currently threatened on the global scale (Hamilton, 2004).

The Himalayas span eight countries (Afghanistan, Bangladesh, Bhutan, China, India, Myanmar, Nepal and Pakistan), all of which are rich in the abundance and diversity of valuable medicinalplant species. The Himalayas cover $18 \%$ of the Indian subcontinent and harbor about 8000 species of angiosperms, 1748 of which are used medicinally (Kala, 2005). Medicinal plants (MPs) form a high percentage of non-timber forest products (NTFPs) collected from the Himalayas, and a large number of them are highly threatened due to the escalating demand for medicinal plant products (Ghimire et al. 2005) as well as from widespread forest transformations. The sustainability of such NTFPs is not only essential for the conservation of plant species, but also for the livelihoods of many rural peoples (Ticktin, 2004). However, it is now recognized that many interlinked dimensions - ecological, biological, socio-cultural and economic - must all be considered in order to achieve sustainable use of NTFPs (Ghimire et al. 2005).

Pakistan has a total geographical area of $796,095 \mathrm{~km}^{2}$ with an altitudinal range of 0 to $8611 \mathrm{~m}$ asl. The country has a variety of climatic zones, diverse soil conditions, multiple ecological zones and a unique biodiversity. Pakistan's forest area comprises $4.8 \%$ of the country's total 
geographical area with a deforestation rate of $1.5 \%$ having been recorded (FAO, 2005), and coniferous forest comprises $40 \%$ of the total forest area (Aftab and Hickey, 2010). The flora of Pakistan is very rich as nearly 6000 thousand higher plants are reported from Pakistan, including 33\% NTFP species (GOP, 2007; Haq et al., 2010), with about 400 species being endemic to Pakistan (Ali, 2008). Around $600(10 \%)$ of all reported species are currently being used as medicinal plants, of which the majority occur in the Himalayan region (Shinwari, 2010). Of these species, 500 are commonly used in traditional healthcare practices and 350 are traded for millions of US dollars on national and international markets (Ahmad, 2003). Most of the medicinal plants that are available in the market or pharmaceutical/herbal industries are extracted from the natural forests (Ahmad, 2003). Approximately 450 medicinal plants are used by the herbal industries for the manufacture of 350 classical formulations to treat various ailments (Ahmad and Husain, 2008), but approximately 90\% of the country's medicinal herb requirement is imported (Gill, 2003). Traditional medicine has dominated in Pakistan since its Vedic origin in around 450-600 BC (Ahmad, 2003). The Greek culture modified the Vedic tradition and formed the popular Unani system, which was later modified by Muslim culture into Hikmat or Tibb (Ahmad, 2003). Today, over 50\% of the population in Pakistan is most commonly treated by some 50,000 practitioners of traditional medicine (Gill, 2003).

Medicinal plants have always had a special place in rural communities. In total, $6.5 \%$ of the country's human population are currently residing in the mountainous forested regions, including the Himalaya, with an annual growth rate of $1.6 \%$ (Siddiqui et al., 1999), and they are heavily dependent on the forest resources (Shinwari, 2010). The increasing trend of plant-use for traditional medicine is due to the general lack of access to modern healthcare facilities for rural people (Ahmad, 2003). The availability of effective herbs coupled with the traditional knowledge of pharmacology and relative lack of side effects make medicinal plant treatment more attractive than allopathic treatments (Ahmad, 2003). Some of the plants are harvested commercially for the extraction of various types of active ingredients, which employs roughly $10 \%$ of the rural population on a full-time basis with around 30\% being employed part-time (Ahmad, 2003; Shinwari, 2010). 
The forests of northwest Pakistan host the majority of traded medicinal plants (Shinwari, 2010); however, these forests are subject to anthropogenic disturbances that have changed the structure of some near-natural old-growth forests into various kinds of degraded forest-use types. Most of the medicinal plant species are understory herbs. Habitat degradation due to deforestation, overgrazing, extension of agricultural lands and the current general management system are threatening the existence of several medicinal plant species (Ahmad, 2003). It is a matter of concern that the country's great diversity and ecosystems are subject to natural habitat loss, with 14.7\% of forest habitat disappearing between 1990 and 2005 (Tahir et al., 2010), which also may have contributed to the disastrous flooding that struck Pakistan in 2010. Loss and degradation of natural old-growth forest is related to a decline in the composition, abundance and diversity of species (Siddiqui et al., 1999; GOP, 2007) and particularly understory medicinal plants.

\subsection{MEDICINAL PLANTS UNDER FOREST TRANSFORMATION}

Forest structure has a direct link with the diversity and abundance of understory medicinal plants (Taverna et al., 2005; Gilliam, 2007). Forest structure is both a product and a driver of ecosystem processes and biological diversity, and if it changes due to natural or anthropogenic disturbances, there may be consequences for other forest components (Foster et al., 1997; Spies, 1998; Fuhrer, 2000). Studies have revealed that anthropogenic disturbances such as heavy logging, grazing, over and improper collection of NTFPs, and the conversion of forested land to other forest-use types might affect the availability of certain forest products on which the locals are dependent such as medicinal plants (García-Montiel and Scatena, 1994; Shanley and Luz, 2003).

Changes in the structure of Himalayan forests due to degradation and deforestation have been reported in many studies (Kumar and Ram, 2005; Nath et al., 2005). The region hosts a vast number of wild plant species (Olsen, 2005) and the importance of medicinal plants from ecological, social and economic perspectives is increasingly recognized in the Himalayan region (Arnold and Pérez, 2001; Hamilton, 2004). Despite its significance to rural livelihoods, the abundance and diversity of understory medicinal plant species are also being threatened by changes in the structural attributes of the overstory within native old-growth forests as a result of 
degradation (D'Amato et al., 2009; Wyatt and Silman, 2010). In many regions of the world, structural changes could be attributed to alterations in the overstory, which in turn influence understory density, cover, frequency and biomass (Gilliam, 2007; D'Amato et al., 2009). Such changes in forest structure may even lead to local extinctions of certain species where changes in the forest structure persist over long periods of time (Vellend et al., 2006). Mishra et al. (2004) confirmed that structural changes in Himalayan forests lead to rapid declines in both diversity and abundance of understory species.

On the other hand, it has been reported that if degraded forest are allowed to re-grow or are planted, the probability of re-occurrence of understory species may increase (Parrotta et al., 1997; Barbier et al., 2008). Forest restoration can accelerate forest succession on a previously degraded site by influencing light availability, understory microclimate, vegetation structural complexity and development of humus layers during the early years of plantation growth (Parrotta et al., 1997; Yirdaw, 2001). For instance, assuming that forest degradation with declining forest tree canopy cover (Lamb et al., 2005) causes lowering abundance of medicinal plants, where forests are restored, medicinal plant abundance can recover and even improve under natural re-growth forest, as opposed to plantation forest (Figure 1.1). However, such studies are scarce in the Himalayan forests, particularly in Pakistan, and the evaluation of the extent to which forest degradation and subsequent forest restoration bring about changes in the abundance and diversity of understory flora has not been possible hitherto.

This study therefore provides an opportunity to address the questions as to how forest transformation changes the abundance and diversity of medicinal plants and whether the recovery of such species is possible under re-growth conditions in the moist forests of the Himalayas. 


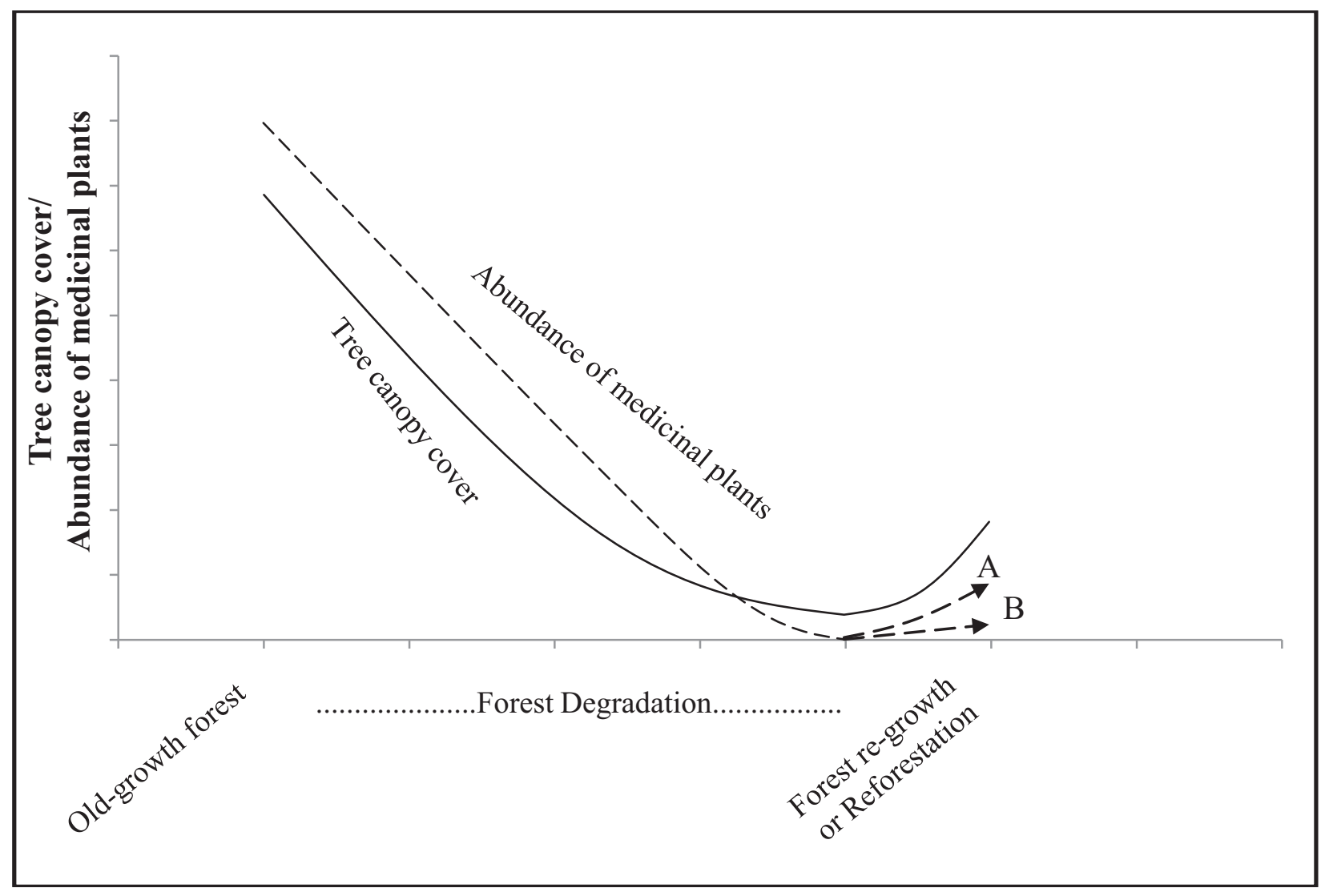

Figure 1.1 A conceptual diagram of change in the tree canopy cover and abundance of medicinal plants due to forest degradation and forest restoration (forest re-growth or reforestation). Tree canopy cover is shown as a solid line, and the corresponding change in the abundance of medicinal plants is shown as dotted lines. Declines in the abundance of medicinal plants occur as tree canopy cover declines, although the magnitude of this loss depends on the type and intensity of forest degradation. When forest restoration begins to occur, it increases tree canopy cover, but any corresponding change in the abundance of medicinal plants depends on the types of forest restoration carried out. Trend A explains natural forest re-growth of native tree species; trend B shows reforestation sites of planted fast-growing tree species. This figure has been developed from the study of Lamb et al. (2005).

\subsection{STUDY OBJECTIVES AND HYPOTHESES}

\subsubsection{Objectives}

- To compare the abundance and diversity of medicinal plants among differently transformed forests.

- To assess the relationship between forest tree structural variables, and diversity and abundance of medicinal plants. 
- To investigate medicinal plant recovery potential in re-growth forest and reforested sites, and to make a respective comparison.

\subsubsection{Hypotheses}

- Medicinal plant abundance and diversity in undisturbed Himalayan old-growth forest stands are higher than in any other forest-use types for the same region.

- Forest degradation is inversely associated with medicinal plant abundance.

- Medicinal plant populations recover more readily in re-growth forest than in planted forest.

\subsection{STUDY AREA}

\subsubsection{Location, area and demography}

The study was carried out in the Khyber Pakhtunkhwa (KPK) province, the former Northwest Frontier Province of Pakistan, which constitutes 40\% of the country's forested area (Lubna, 2001). Forests cover $17 \%$ of the province (WWF-P, 2004) and stretch across the Himalayas, Hindu Kush and Karakurum mountain ranges. Covering an area of 3,312 ha, the Ayubia National Park (ANP) is one of 21 national parks in Pakistan and is situated between $33^{\circ}-01^{\prime}$ to $34^{\circ}-38^{\prime} \mathrm{N}$ latitude and $73^{\circ}-20^{\prime}$ to $73^{\circ}-30^{\prime}$ E longitude (Fig. 3.1B). The study covers the ANP and its surrounding forests, which together constitute 8,978 ha in area. The study area ranges from 1,220 $\mathrm{m}$ to $2,865 \mathrm{~m}$ in altitude, with Miranjani being the highest peak (Hussain, 2003). The ANP and its surrounding forests lie within reach of the monsoon and have a mean annual precipitation of 1,500 mm. There is snow cover between November and March and the mean annual temperature is $12{ }^{\circ} \mathrm{C}$ (WWF-P, 2004). ANP is demarcated by a watershed line between Mukshpuri top and Dunga Gali in the north, Mukshpuri top and Khanaspur ridge in the east, metallic road between Dunga Gali and Kooza Gali in the west, and metallic road from Kooza Gali to Khanaspur via Ayubia town in the south. The Park headquarters is at Dunga Gali, $34 \mathrm{~km}$ southeast of Abbottabad city (Lodhi, 2007) and $75 \mathrm{~km}$ from the capital city of Islamabad (Shafiq, 2003).

Approximately 50,000 people currently live in 12 villages around the ANP. The major ethnic groups of the area are Karalls and Abbasis (Hazaary-wall), who speak Hindku and or Potohari. 
The distance of villages to the national park varies from one to three kilometers (Shafiq, 2003). The society is predominantly male dominated due to a high illiteracy rate among women. Pleasant weather and dense vegetation in and around the ANP attract large numbers of tourists in summer to the main town of Nathiagali, while people often come in winter to enjoy the snow fall. Local men usually conduct business while women do most of the house keeping, agriculture, and collection of fuelwood and fodder.

\subsubsection{Forest administration and management}

The administration and management approach of the forests dates back to 1857 following British colonization, when they were designated "reserved" forests and "Guzara" forests. A part of the reserved forest was declared National Park in 1984 with an area of 1,684 ha (Ayubia National Park, ANP) and the management was handed over to the KPK wildlife department under the authoritative control of divisional forest and range officers. The area of the ANP was later increased to 3,312 ha by decree of the KPK. The name of the park was derived from the town of Ayubia located at its southern end (Farooque, 2002; WWF-P, 2004). The purpose of the Park is to conserve the unique flora and fauna of the moist temperate western Himalayan ecosystem (Lodhi, 2007). National Parks are large tracts of land having outstanding scenic merit and are of national interest. The primary function is to protect landscape, flora and fauna in their natural state. Public access is allowed for recreation, education and research. Certain activities, such as hunting and the trapping of animals and the destruction of flora, are strictly prohibited (WWF-P, 2004).

\subsubsection{Guzara forests}

Guzara forests are private forests owned by the villagers to meet their domestic requirements for forest products. These forests are under the administrative and management control of the KPK Forest Department. The exploitation of Guzara forests is done in accordance with planned prescriptions. A committee chaired by the local Deputy Commissioner with officials of the Forest Department and local influential people look after the matters of distribution of yield according to the requirements of right holders. All the offenses in Guzara forests are dealt with under the Hazara Forest Act 1937 (WWF-P, 2004). 


\subsubsection{Reserved forests}

Reserved forests are defined as forests in which any human disturbance is prohibited unless permitted by the Government. All revenue from sales of reserved forest goes to the Government treasury and the KPK Forest Department is responsible for the protection and management of these forests. These forests are presently managed under a selection system of forest management and there are certain areas within reserved forests that are subject to particular rights afforded to local communities. The right holders are the people who were affected by the reservation of these forests or those who had no private forest. These rights and concessions concern simply rights of way, access to water sources, rights of grazing, fodder and fuelwood collection and some timber rights. Nowadays, due to the rapidly rising population and an increase in demand, people are illegally utilizing the resources of reserved forests and some parts of the national park. People often misuse the concessions granted to them and in this way and inflict heavy damages on the forest through illegal logging, grazing and fodder collection. Punishments for all offenses are governed under the Pakistan Forest Act 1927 (WWF-P, 2004).

\subsubsection{Land use, agriculture and livestock}

The main land uses of the area are for agriculture, commercial forest and as pasture/meadow. Agricultural lands are located around the settlements and mostly on slopes. Potato, cauliflower, beans, maize and wheat are the major agricultural crops of the area. Farmers mostly use farmyard manure as fertilizer on crops and strong winds and hailstorms frequently damage crops in the area. Small water channels, tributaries and springs respectively provide drainage, irrigation and drinking water for the inhabitants of the area (Sher and Hussain, 2007).

Total livestock population in the area is about 27,181 including goats $(8,526)$, cows $(4,370)$, buffaloes (14,076), horses (95) and donkeys (114) (Rabia and Khan, 2004). The average number of animals per household is one buffalo and one goat (Jabeen, 1999). Livestock numbers and their role in the economy of the area are complicated. Most of the families have small numbers of local chickens for domestic use. Hair and wool obtained from goats and sheep are used in the manufacture of warm clothes, carpets and handicrafts (Rabia and Khan, 2004). 


\subsubsection{Soil and geology}

Soils are often shallow and of a loamy texture. In grazing areas, soil is shallow with exposed bedrock due to the high incidence of biotic activities. The present geological structure is a result of the extensive folding, shearing and faulting associated with regional crystal deformation arising from the northward seduction of the Indian sub continental plate below the europium plate. The major rock types are limestone, slate and a metamorphic series of phylites, schist and granite with a fair depth of mineral soil capable of supporting an average quality of blue pine and fir crops, such as those in the adjoining reserved forests (Khalil and Hussain, 2008). Rocks of the study area belong to the Margala Hill limestone of Eocene age. Margala Hill limestone is mainly limestone with subordinate marl and shale. The limestone is grey, fine to medium-grained, nodular, medium to thick-bedded and rarely massive. The marl is grey to brownish-grey while the shale is greenish-brown to brown in color. Moreover, rocks of the Kawagarh Formation of the Cretaceous age, Lokhart limestone, Patala Formation of Paleocene age, and Chorgali Formation of the Eocene age are also exposed in the area (Waagen, 1872; Middlemiss, 1896; Shafiq, 2003).

\subsubsection{Fauna}

ANP harbors a variety of wildlife species such as Rhesus monkeys, common leopards, yellowthroated martins, flying squirrels, koklas and chukors. Approximately 200 species of bird, 31 species of mammal, 16 species of reptile, three species of amphibian, 23 species of butterfly and 650 described species of insect are reported for the area (Lodhi, 2007; Shafiq, 2003). Leopards have also been declared an endangered species that need protection (WWF-P, 2004).

\subsubsection{Flora}

The Park is comprised of sub-alpine meadows, moist temperate forests and the sub-tropical pine forest ecotype (Aumeeruddy et al., 2004; Lodhi, 2007). Pastures provide nutrients, feed for livestock and some wildlife. Around 410 species of combined vegetation have been reported from the study area belonging to Fungi, Lichens, Pteridophytes and Spermatophytes (Shafiq, 2003). Of these, about 200 are reported to be herb species including ferns (Shinwari, 2010). Many of them are of medicinal and economic importance and the dominant tree species are 
Abies pindrow Royel, Cedrus deodara G. Don, Pinus roxburghii Sargent, Pinus wallichiana A.B. Jacks, Quercus incana Roxb and Taxus wallichiana Zacc (Shafiq, 2003).

Around 100 herb species are reported to be medicinal plants that are traditionally used for the treatment of various human diseases and for ethno-veterinary (Shafiq, 2003; WWF-P, 2004; Ali, 2011). Most local names of medicinal plants are in two languages, namely Hindko (spoken in the study area) and Pashto (spoken in most parts of northwest Pakistan). Each plant is either used for only one part or several parts such as leaves, the whole plant, roots or tubers, stems or bark, flowers and seeds or fruits. All medicinal plant species are also used as fodder, vegetables, insecticides, fruits, narcotics, cosmetics, handicrafts, dyes, tea and others (plant breeding, fish poison, shade, writing ink, bees attractant and spiritual purposes). Medicinally, plants are used for curing diseases such as intestinal or stomach problems, fever, chest pains, inflammatory diseases, skin conditions, urinary problems, as a tonic, muscular pains, headaches, toothache, ENT (ear, nose, throat) conditions, liver and spleen problems, insect and pest bites, eye infections, STDs, angina, diabetes and finally as anti-carcinogenic treatments (see Annexure) (Ibrar, 2003; Shafiq, 2003; WWF-P, 2004). Children are mostly employed in the collection of medicinal plants (47\%), women in the processing $(55 \%)$ and men in the marketing $(70 \%)$ (Adnan et al., 2006). Indigenous ethno-botanical knowledge at ANP has been transmitted orally from generation to generation maintaining strong interrelationships between people and plants (Gilani et al., 2001).

\subsubsection{Major conservation issues}

\subsubsection{Land tenure system}

The land tenure system of the areas is reported in detail in the ANP Management Plan (Farooque, 2002). There are some complexities in the land tenure laws and the actual status of what is supposed to be Guzara forest is sometimes unclear to local people. Most of the people do not know about their rights in Guzaras, forests have also not been properly demarcated, and in some cases, reserved forests in which the people have been granted rights are consequently treated as Guzaras. The free ranging of goats and other livestock coupled with fodder collection 
is currently being practiced in most of the Guzara forests. Degraded and deforested lands are encountered more within Guzara forest zones, and some parts have also been reforested with native trees (WWF-P, 2004). The empowerment of local communities in the Guzara forests with clear management prescriptions may provide a potential alternative to reducing the pressure on the national park (Lodhi, 2007). Certain forest areas are under the cultivation of fast growing tree species, fruit trees and other native tree species.

\subsubsection{Grazing and fodder collection}

The community living around the park is dependent on its resources for fodder collection and livestock grazing (Aumeeruddy et al., 2004). Women collect large quantities of fodder including herbaceous species from the Guzara forests and some reserved forests during summer and store it for winter use (13.3 tons fresh weight/year/household). The time period of fodder collection starts from April and ends in September each year. Although locals prefer to use grasses as fodder, they still collect herbaceous flora, including economically important medicinal plants, due to a lack of awareness of restrictions in this respect. Rabia and Khan (2004) estimated that around $34 \%$ of collected fresh fodder per household per year consisted of medicinal plants.

In addition, the grazing of livestock in the Park is also common. These activities are regarded as the major causes of forest degradation in the entire area. During summer, the rearing of animals such as goats, cows, buffaloes and oxen is a common practice in Guzara forests and in some pastures within the park. These animals are taken back during October and are fed on stored fodder. Grazing has greatly affected the regeneration of plant species in the Park (Aumeeruddy et al., 2004). Young seedlings are either trampled or are eaten by animals. The ground also becomes hard due to compaction and the chances of germination of seeds lying on the ground are reduced (Lodhi, 2007). According to a study in a similar region of northwest Pakistan, it was revealed that grazing poses a serious threat to the occurrence and the distribution of medicinal flora. The study confirmed that sites protected from grazing possess $60 \%$ more diversity than unprotected sites (Sher et al., 2010). 


\subsubsection{Fuelwood and timber requirements}

Due to the rapidly rising population and associated increase in demand for forest services, some people have adopted illegal ways of exploiting resources from the reserved forests. Fuelwood collection and timber harvesting form an integral activity of the community around the park in order to sustain livelihoods as no cheaper substitute for fuelwood is available. Aumeeruddy et al. (2004) reported that surrounding population of the ANP collect fuelwood from the forest despite legal restrictions, which can lead to resource depletion within the park. Mostly, the women collect fuelwood in the form of deadwood, by pruning green branches and felling small trees (Aumeeruddy et al., 2004). Abies pindrow, Pinus sp., Quercus sp. and Taxus wallichiana are the preferred fuelwood species. The annual dry fuelwood requirement in the study area is around 11 metric tons dry weight/year/household (Sher and Hussain, 2007), which is stored between June and September (Aumeeruddy et al., 2004). Moreover, the illegal trade of wood from the study area is also another practice which is inflicting heavy damage on the vegetation resources of the ANP and its surrounding forests. The trees illegally cut are either used locally for the construction of houses or smuggled to other big cities (WWF-P, 2004).

\subsubsection{Impact of tourism}

Towns around the ANP offer great recreational resources, attracting approximately 0.1-0.2 million tourists each year, particularly in summer (Aumeeruddy et al., 2004). Tourist facilities such as vacation homes, hotels, restaurants, superstores and shops have been observed as a means of exerting pressure on the forest resources in the form of solid waste pollution and associated fuelwood and timber requirements (Waseem et al., 2005). As an estimate, more than 300 metric tons/year of fuelwood is being consumed by hotels and vacation homes.

\subsubsection{Over and improper harvesting of medicinal plants}

The area also hosts many endemic and endangered medicinal plant species, which also carry economic importance (Figs. 1.11, 1.12, 1.13). However, indigenous knowledge of the uses, collection and management of medicinal plant species is quickly eroding. Moreover, over and improper collection of medicinal plants due to a lack of awareness of local collectors is resulting in the area's rapid degradation in terms of valuable flora (Fig. 1.10). 


\subsubsection{Opportunity for research}

People around the ANP are dependent on forest resources including medicinal plants. However, forest logging, grazing, land tenure problems and the over and improper collection of plants have all resulted in rapid declines in the availability of medicinal plants. Deforestation, grazing and fodder collection are some of the factors disturbing the regeneration capacity of medicinal plants (Sher and Hussain, 2007). WWW-Pakistan has consequently initiated various activities in the study area to cope up with these major conservation and development issues. The Applied Ethnobotany Project (1996-2004) was the umbrella project of WWF-Pakistan which addressed these issues and worked closely with the local community with the main objectives being (1) to increase the capacity of communities to conserve biodiversity and provide sustained quantities of plant resources for livelihood security and reduce poverty, and (2) to contribute to the greater sustainability of plant-resource use at the ANP. Several studies were conducted under the project that mainly focused on the effect of un-sustained practices in and around the ANP on forest transformation and their rehabilitation (WWF-P, 2004). This provided an opportunity for this study to investigate the effects of forest transformation on the associated flora, particularly on the medicinal plants, which form an integral part of rural livelihoods.

\subsection{STUDY DESIGN}

\subsubsection{Forest-use types studied}

Field work was carried out in three different periods: July to October 2008; June to September 2009, and August to September 2010. First of all, a reconnaissance survey was conducted to identify the various forest-use types. This was based on information from WWF (World Wide Fund for Nature) Pakistan, the local population, relevant government and other nongovernmental organizations and other available literature. WWF-Pakistan was used as a primary source for the identification of these forest-use types because of their presence and interventions in several parts within the study area. Seven forest-use types have been differentiated on the basis of forest structure, management, land tenure and resource utilization and classified according to the nomenclature proposed by Putz and Redford (2010): 
'Old-growth forest' refers to the forest-use type with little or no human disturbance. It consists of many large diameter trees and the forest canopy is mainly closed (Fig. 1.2). Old-growth forest can mainly be found in the ANP and in surrounding reserve forests and should consequently be afforded the highest level of protection from resource exploitation.

'Forest degraded by logging' refers to forest considerably affected by tree felling where many stumps can be found. It is found in both reserve and Guzara forests and has a relatively open canopy (Fig. 1.3). Such identified areas have been protected from further anthropogenic use since 2009. However, these open forest areas have supported livestock feed provision through grazing and, more commonly, fodder collection. In addition, the collection of valuable medicinal plants species was also common before the introduction of protection measures.

'Derived woodland' refers to forest under high grazing pressure where people frequently collect fodder and medicinal plants (Fig. 1.4). This forest-use type is generally close to villages and is mostly Guzara forest that contributes a major portion to the livestock fodder consumption. Legal and illegal logging has taken place in the recent past and still continues on a small scale. The regeneration of native trees is very limited due to grazing and collection activities coupled with coppicing. Large amounts of fodder, mainly grasses and herbaceous species, are collected by women from May to November each year (Rabia and Khan, 2004).

'Agroforest' indicates areas of intense, long-term, cultivation where maize, potato, vegetables and some fodder species have been cultivated over the years (Fig. 1.5). This land use type often represents former derived woodland and is more common on private land; however, due to the unclear land tenure system, some parts of Guzara lands have been encroached upon for the cultivation of agricultural crops, fruit trees such as peach, pears and apricots, fast growing tree species (Populus sp, Salix sp etc), other native trees (Pinus wallichiana, Ulmus wallichiana etc.) and some grass species (Sorghum). 


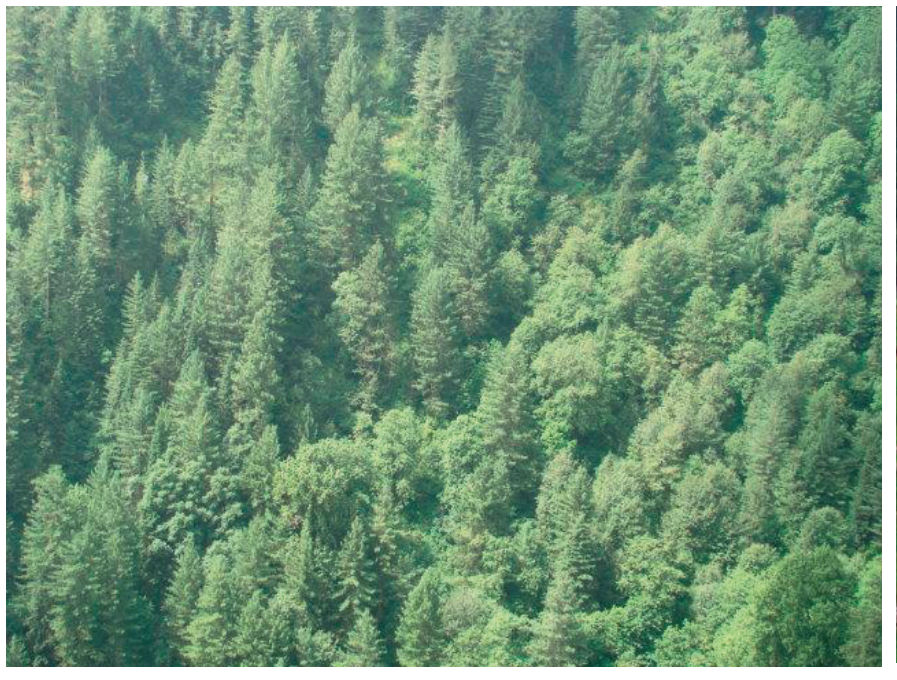

Figure 1.2 Old-growth forest.

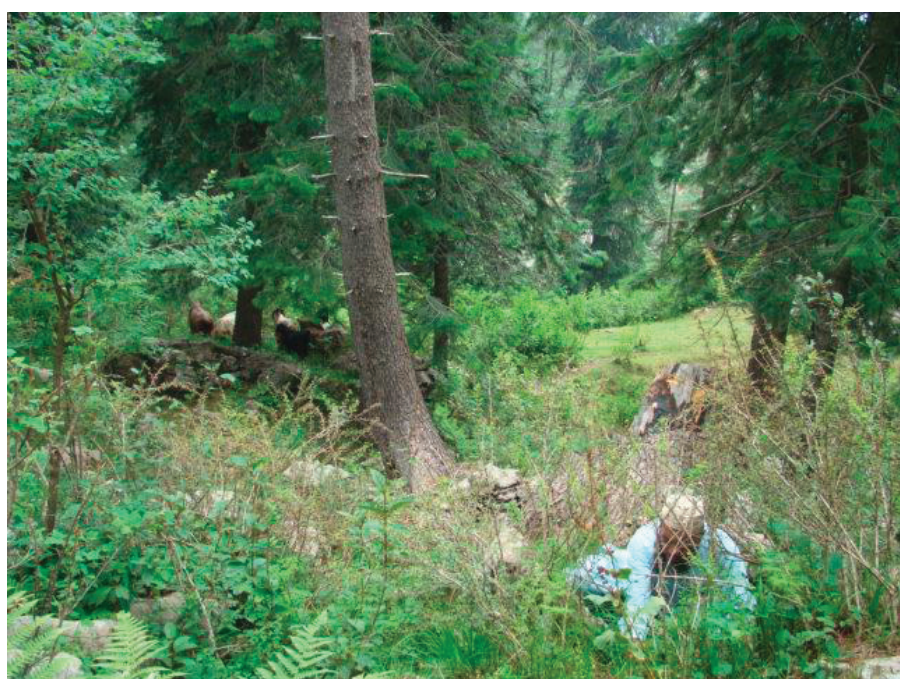

Figure 1.4 Derived woodland.

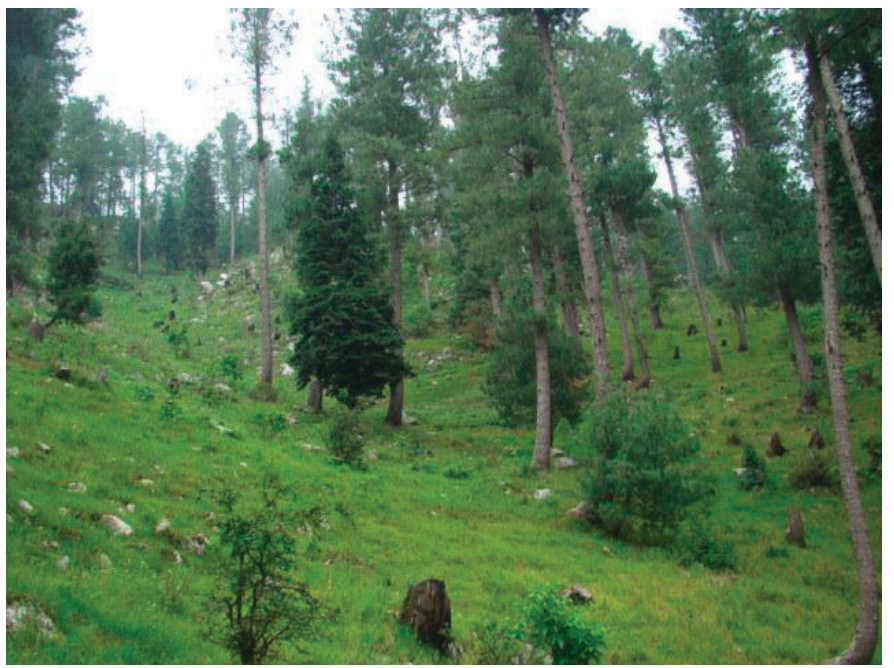

Figure 1.3 Forest degraded by logging.

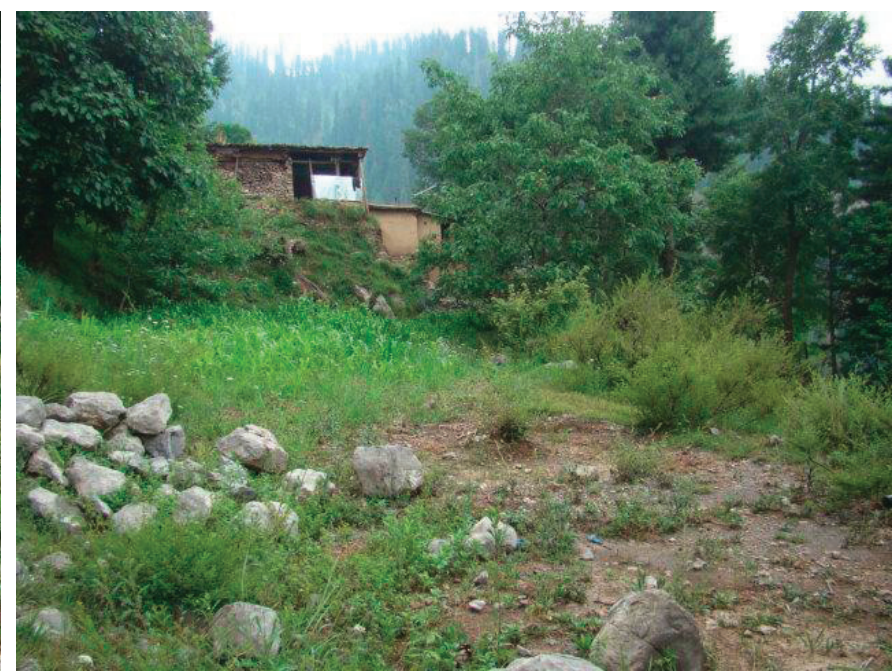

Figure 1.5 Agroforest. 


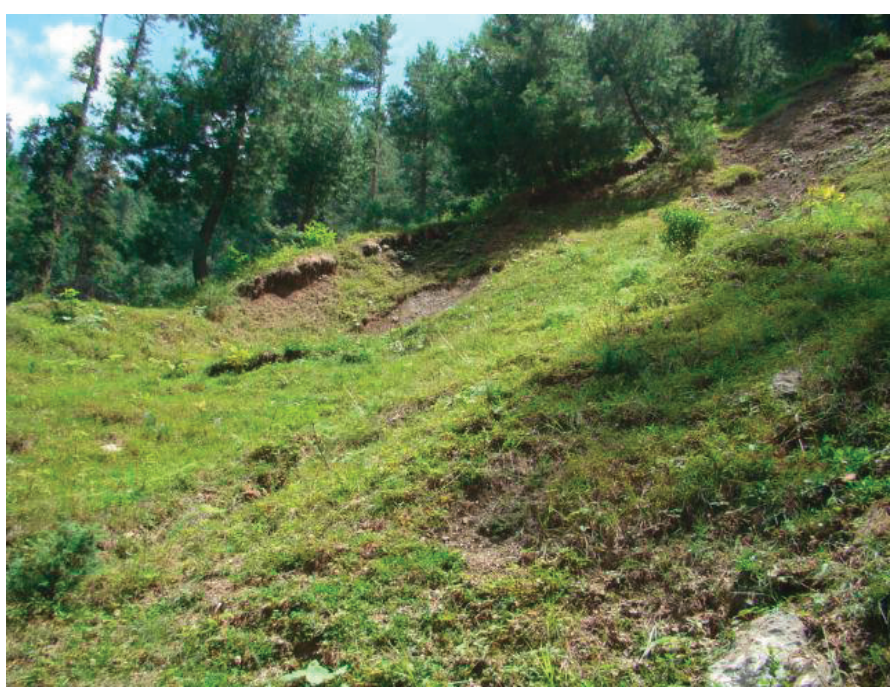

Figure 1.6 Degraded sites.

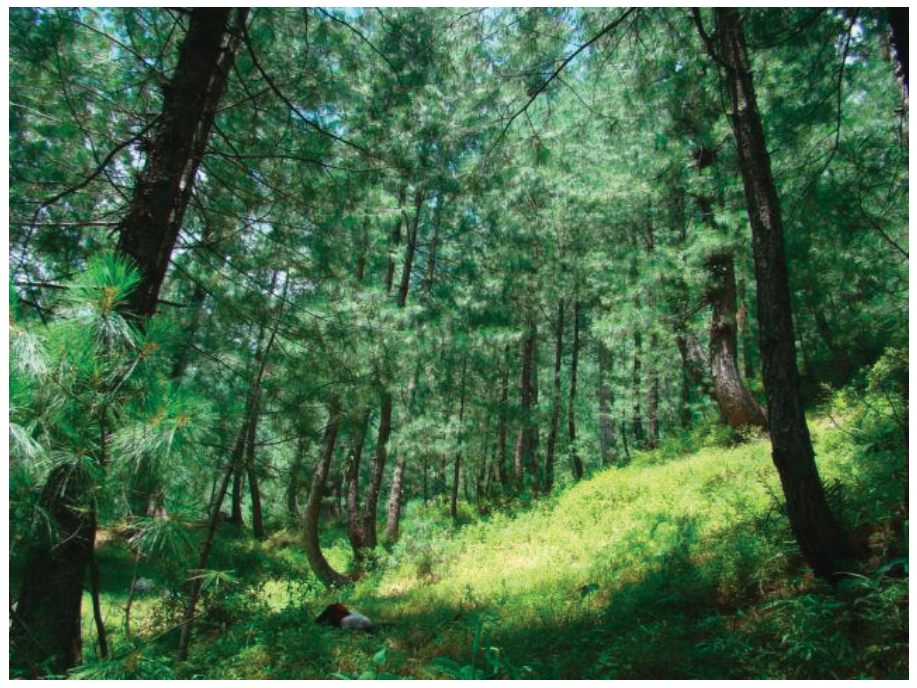

Figure 1.8 Re-growth forest.

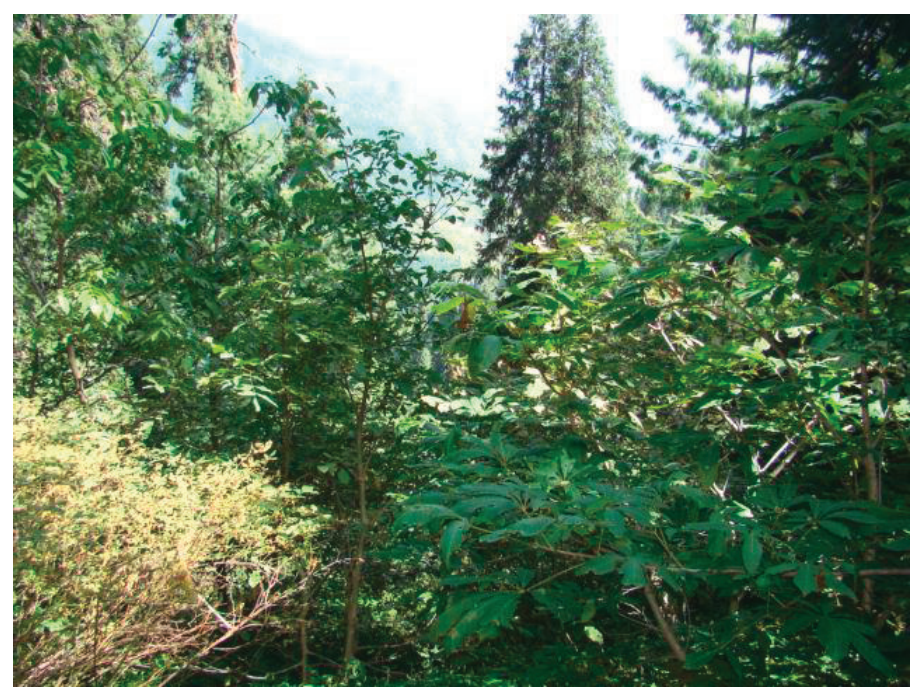

Figure 1.7 Reforestation sites.

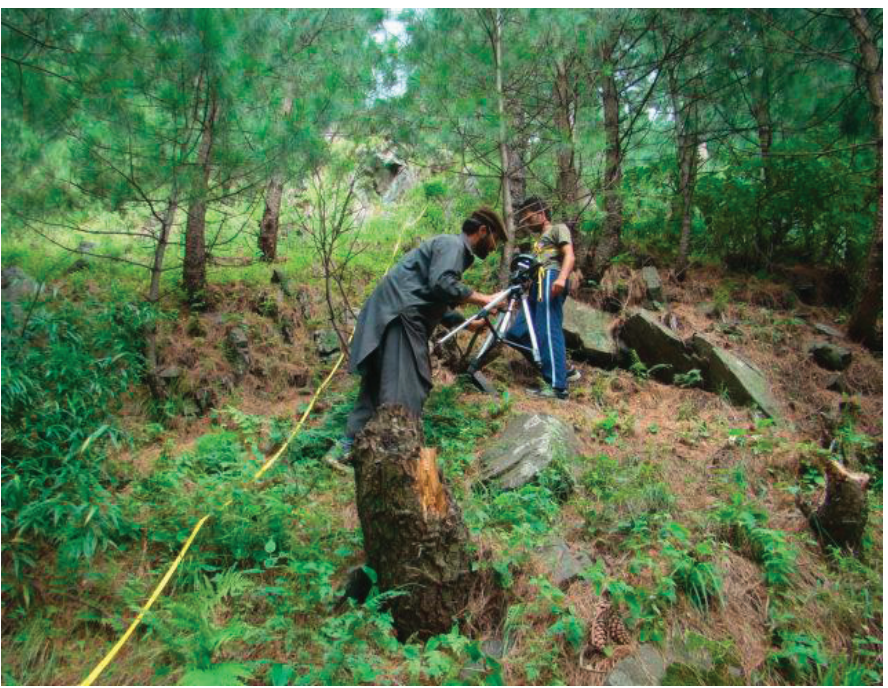

Figure 1.9 Establishment of inventory plot and taking hemispherical photograph 


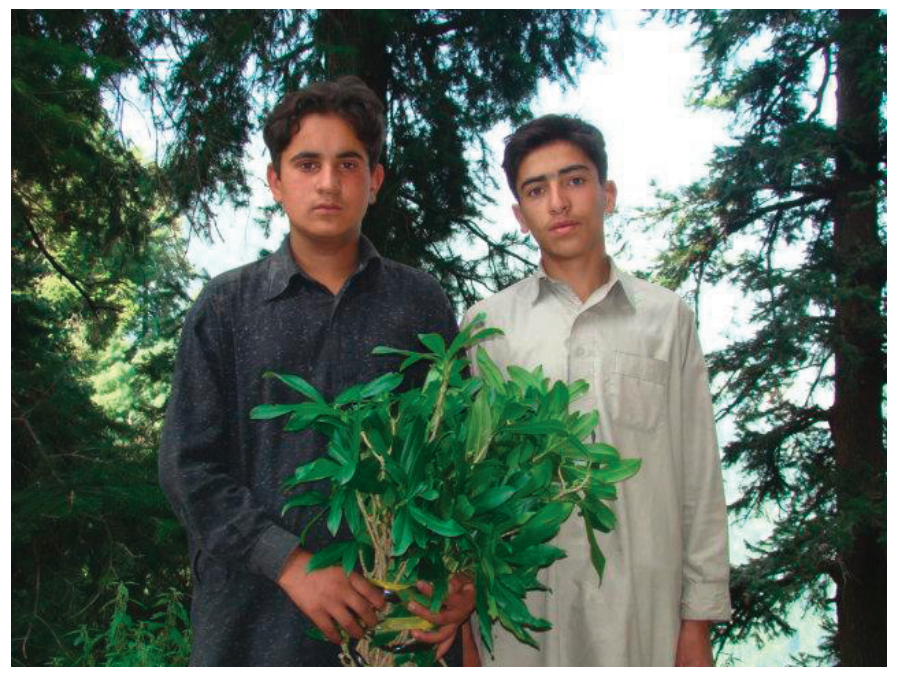

Figure 1.10 Medicinal plants collectors

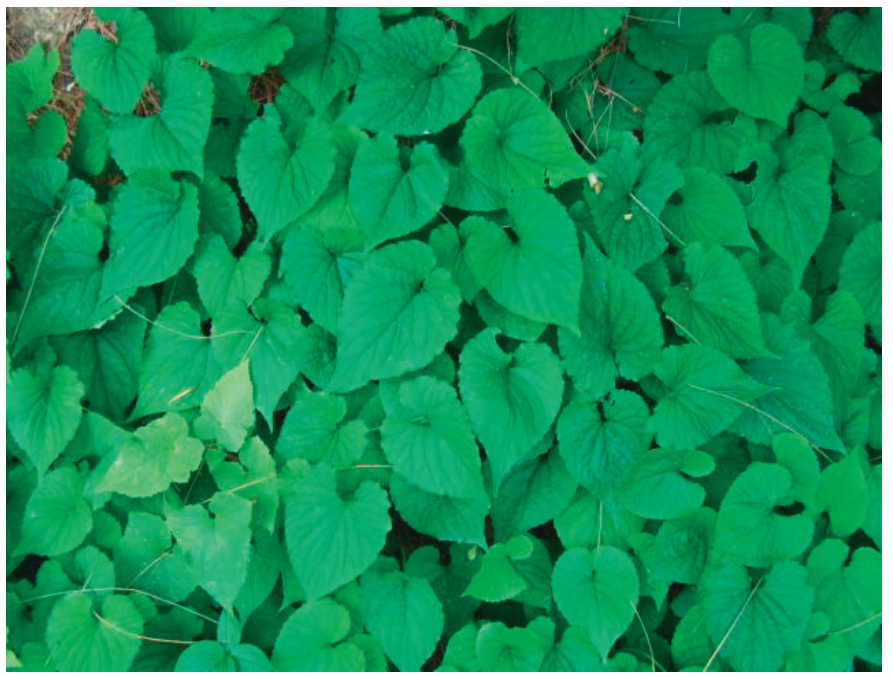

Figure 1.12 Valeriana jatamansi Wall.

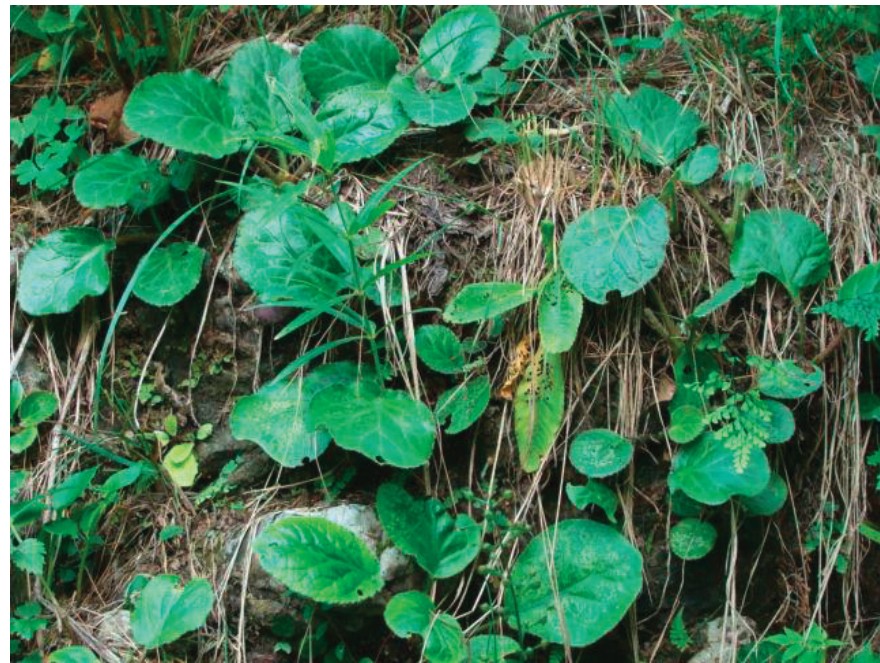

Figure 1.11 Bergenia ciliata (Haw.) Sternb.

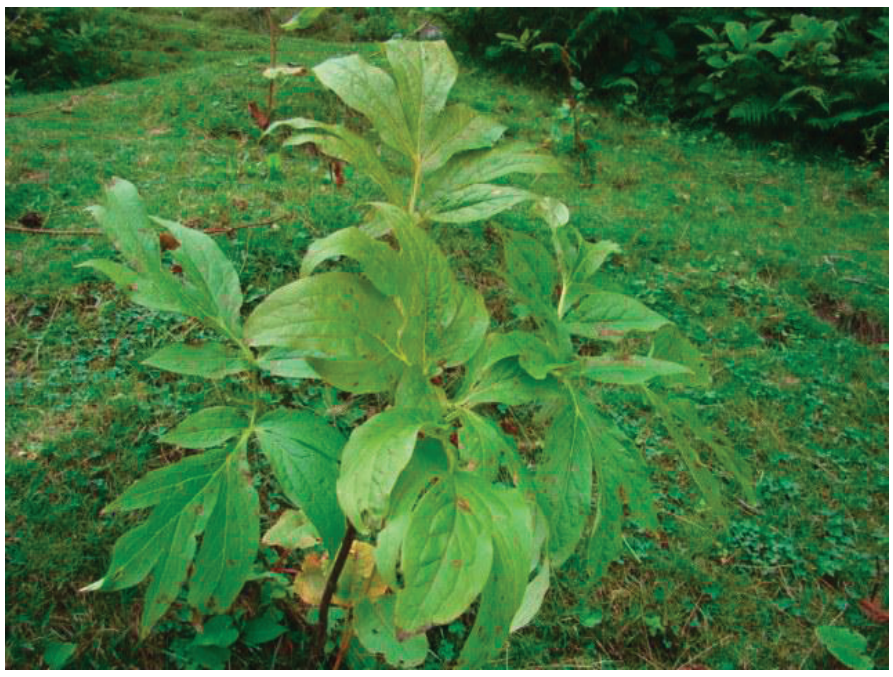

Figure 1.13 Paeonia emodi Wall. ex Royle. 
'Degraded areas' refer to former old-growth forest that has been deforested during the last three or four decades, leaving only a few Pinus wallichiana trees (Fig. 1.6). It has an open access to grazing animals and locals for fodder collection.

'Reforested areas' refers to formerly degraded areas planted with four native tree species (Robinia pseudo-acacia L., Aesculus indica Colebr, Populus ciliata Wall. ex Royle and Salix tetrasperma Roxb) in mixture at an initial spacing of $1 \mathrm{~m}^{2}$ (Fig. 1.7). Free access to grazing animals and locals for fodder collection was previously allowed; however, $60 \%$ of the reforested area was protected during the initial planting period (WWF-P, 2004).

'Re-growth forests' are areas currently regenerating after heavy logging. They consist of many narrow diameter trees, have a high stem density and generally occur within reserve forests and the ANP (Fig. 1.8). The existence of some remnant trees identifies these forest-use types as regrowth forests as opposed to the secondary forest, as mentioned in the Putz and Redford (2010) study. Such forests have been free from logging for 20 to 50 years and, like old-growth forest, this forest-use type is also afforded some statutory protection.

\subsubsection{Study sites, plot selection and plot design}

Field visits were made to locate the boundaries of each studied forest-use type and GPS data were recorded, which resulted in approximate maps of forest-use types. In order to select random sample points on the map we used specific software (ILWIS, version 3.4) (ITC, 2007), which selected two random values, one for the $\mathrm{X}$ axis and one for the $\mathrm{Y}$ axis, with the point of intersection representing the sample point. Each random point represented the center of each sample plot. Each plot consisted of a tree inventory plot of $20 \times 20 \mathrm{~m}(400 \mathrm{~m} 2)$ and a plot strip of $20 \times 2 \mathrm{~m}(40 \mathrm{~m} 2)$ within each inventory plot for the assessment of medicinal plants (Figs. 1.9, $2.1,3.1,4.1)$.

The first study (Chapter 2) was conducted in old-growth forest, forest degraded by logging and in re-growth forest to assess the diversity of medicinal plants (all herbs and ferns). The second study (Chapter 3) was conducted in old-growth forest, forest degraded by logging, derived 
woodland, agroforest and re-growth forest. Fifteen study plots were randomly selected within each forest-use type using a GIS map within an altitudinal range between 2,200 $\mathrm{m}$ and 2,400 $\mathrm{m}$ asl (Fig. 3.1). The selected study plots had mainly northern aspects and lay on inclines ranging from $2-35 \%$. The third study (Chapter 4 ) was conducted in degraded and reforested areas. Five random sample points (five plots) were allocated to each of the two forest-use types using the GIS derived map (Fig. 4.1). In the second and third studies, only ten medicinal plant species (all herbs) were selected for assessment on the basis of their high market value and their extensive use in traditional medicine, and they were relatively easy to identify in the field. In addition, the forest structure of each forest-use type was also studied.

\subsection{REFERENCES}

Adnan, S.M., Khan, A.A., Abdul, L.K., Zabta, K.S., 2006. Threats to the sustainability of ethnomedicinal uses in northern Pakistan; a case history of Miandam valley, district Swat, NWFP, Pakistan. Lyonia 11, 91-100.

Aftab, E., Hickey, G.M., 2010. Forest administration challenges in Pakistan: The case of the Patriata reserved forest and the 'New Murree' development. International Forestry Review $12,97-105$.

Ahmad, H., 2003. Capacity building for cultivation and sustainable harvesting of medicinal and aromatic plants. In: Ahmad H, Khan AA, editors. Proceeding of international workshop on conservation and sustainable uses of medicinal and aromatic plants in Pakistan, WWFPakistan. pp. 31-36.

Ahmad, S.S., Husain, S.Z., 2008. Ethno medicinal survey of plants from salt range (Kalar Kahar) of Pakistan. Pakistan Journal of Botany 40, 1005-1011.

Ali, S.I., 2008. Significance of flora with special reference to Pakistan. Pakistan Journal of Botany 40, 967-971.

Ali, S.I., 2011. Flora of Pakistan. http://www.efloras.org/flora page.aspx?flora id=5; accessed on 07 May, 2011.

Arnold, J.E.M., Ruiz, P.M., 2001. Can non-timber forest products match tropical forest conservation and development objectives? Ecological Economics 39, 437-447. 
Aumeeruddy, T.Y., Shinwari, Z.K., Ayaz., A., Khan, A.A., 2004. Ethnobotany and management of fodder and fuelwood at Ayubia National Park, Northwest Frontier Province, Pakistan (People and plants working paper). International plants conservation unit, WWF-UK. www.peopleandplants.org/storage/working-papers/wp13.pdf; accessed on 15 July 2011.

Barbier, S., Gosselin, F., Balandier, P., 2008. Influence of tree species on understory vegetation diversity and mechanisms involved-A critical review for temperate and boreal forests. Forest Ecology and Management 254, 1-15.

D'Amato, A.W., Orwig, D.A., Foster, D.R., 2009. Understory vegetation in old-growth and second-growth Tsuga canadensis forests in western Massachusetts. Forest Ecology and Management 257, 1043-1052.

FAO (Food and Agriculture Organization)., 2005. State of the world's forests-2005. Rome, Italy. Farooque, M., 2002. Management Plan of Ayubia National Park 2002-2007. Natural resource conservation project, Galiat, Abbottabad.

Foster, D.R., Aber, J.D., Melillo, J.M., Bowden, R.D., Bazzaz, F.A., 1997. Forest response to disturbance and anthropogenic stress. Bioscience 47, 437-445.

Fuhrer, E., 2000. Forest functions, ecosystem stability and management. Forest Ecology and Management 132, 29-38.

García-Montiel, D.C., Scatena, F.N., 1994. The effect of human activity on the structure and composition of a tropical forest in Puerto Rico. Forest Ecology and Management 63, 5778.

Ghimire, S.K., McKey, D., Aumeeruddy, T.Y., 2005. Conservation of Himalayan medicinal plants: Harvesting patterns and ecology of two threatened species, Nardostachys grandiflora DC. and Neopicrorhiza scrophulariiflora (Pennell) Hong. Biological Conservation $124,463-475$.

Gilani, S.A., Qureshi, R.A., Farooq, U., 2001. Ethnobotanical studies of Ayubia National Park, District Abbottabad, Pakistan. Journal of Biological Sciences 1, 284-286.

Gill, M.A., 2003. Cultivation of medicinal and aromatic herbs: experience of IMHSC. In: Ahmad H, Khan AA, editors. Proceeding of international workshop on conservation and sustainable uses of medicinal and aromatic plants in Pakistan, WWF-Pakistan. pp. 22-30. 
Gilliam, F.S., 2007. The ecological significance of the herbaceous layer in temperate forest ecosystems. Bioscience 57, 845-858.

GOP (Government of Pakistan)., 2007. First national report of Pakistan to the convention on biological diversity. Ministry of environment, Islamabad, PK. http://www.cbd.int/doc/world/pk/pk-nr-01-en.pdf; accessed on 06 September 2010.

Hamilton, A.C., 2004. Medicinal plants, conservation and livelihoods. Biodiversity and Conservation 13, 1477-1517.

Haq, F.U., Ahmad, H., Alam, M., Ahmad, I., Ullah, R., 2010. Species diversity of vascular plants of Nandiar valley western Himalaya, Pakistan. Pakistan Journal of Botany 42 (special issue): $213-229$.

Hussain, K., 2003. Impact of grazing on infiltration capacity of soil (Report). Peshawar, Pakistan: WWF-P Peshawar office.

Ibrar, M., 2003. Conservation of indigenous medicinal plants and their traditional knowledge found in moist temperate Himalayas Pakistan ( $\mathrm{PhD}$ thesis). Islamabad, Pakistan: Department of Biological Sciences, Quaid-i-Azam University. http://prr.hec.gov.pk/chapters/1977-0.pdf; accessed on 09 January 2010.

Jabeen, A., 1999. Ethnobotany of fodder species of Ayubia National Park (ANP) Nathiagali; its conservation status and impacts on environment (M.Phil thesis). Islamabad, Pakistan: Quid-I-Azam University.

Kala, C.P., 2005. Indigenous uses, population density, and conservation of threatened medicinal plants in protected areas of the Indian Himalayas. Conservation Biology 19, 368-378.

Khalil, S.R., Hussain, T., 2008. Common Leapard predation on livestock, an assessment of local predation in the Gallies Forest Division, district Abbottabad (Internship Report). Peshawar, Pakistan: Department of Environmental Sciences, University of Peshawar. http://cmsdata.iucn.org/downloads/annex 4.pdf; accessed on 01st July 2011.

Kumar, A., Ram, J., 2005. Anthropogenic disturbances and plant biodiversity in forests of Uttaranchal, central Himalaya. Biodiversity and Conservation 14, 309-331.

Lamb, D., Erskine, P., Parrotta, J., 2005. Restoration of degraded tropical forest landscapes. Science 310, 1628-1632. 
Lodhi, A., 2007. Conservation of Leopards in Ayubia National Park, Pakistan (Master thesis). Missoula, MT, United States: Wildlife Biology, The University of Montana. http://www.cfc.umt.edu/nwfp/docs/AsadLodhiFinalPP.pdf; accessed on 26 June 2011.

Lubna, H., 2001. Analyzing institutional set-up of forest management in Pakistan, Munich personal RePEc archive. MPRA paper no. 7343. mpra.ub.uni-muenchen.de/7343/; accessed on 14 March 2009.

Middlemiss, C.S., 1896. The geology of Hazara and the black mountains. Memoirs of the Geological Survey of India 26, 88-177.

Mishra, B.P., Tripathi, O.P., Tripathi, R.S., Pandey, H.N., 2004. Effect of anthropogenic disturbance on plant diversity and community structure of a sacred grove in Meghalaya, northeast India. Biodiversity and Conservation 13, 421-436.

Nath, P., Arunachalam, A., Khan, M., Arunachalam, K., Barbhuiya, A., 2005. Vegetation analysis and tree population structure of tropical wet evergreen forests in and around Namdapha National Park, northeast India. Biodiversity and Conservation 14, 2109-2136.

Olsen, C.S., 2005. Valuation of commercial central Himalayan medicinal plants. Ambio 34, $607-610$.

Parrotta, J.A., Turnbull, J.W., Jones, N., 1997. Catalyzing native forest regeneration on degraded tropical lands. Forest Ecology and Management 99, 1-7.

Putz, F.E., Redford, K.H., 2010. The importance of defining 'Forest': Tropical forest degradation, deforestation, long-term phase shifts, and future transitions. Biotropica 42, $10-20$.

Rabia, A., Khan, A.A., 2004. Medicinal plants of Ayubia National Park: prospective and constraints. In: Shinwari ZK, Watanabe T, editors. International Symposium on Medicinal Plants: Linkages Beyond National Boundaries. Proceedings 1. Vol 1. Islamabad, Pakistan: Pakistan Agriculture and Research Council, pp 153-161.

Shafiq, C.M., 2003. Some aspect of bio-ecology of Ayubia National Park Northwest Frontier Province, Pakistan (master thesis). Karachi, Pakistan: University of Karachi. http://prr.hec.gov.pk/Thesis/1008.pdf; accessed on 19 October, 2010.

Shanley, P., Luz, L., 2003. The impacts of forest degradation non medicinal plant use and implications for health care in eastern Amazonia. Bioscience 53, 573-584. 
Sher, H., Hussain, K., 2007. Rapid vulnerability assessment (RVA) [report on Ayubia National Park]. World Wide Fund for Nature Pakistan, Peshawar Office, Khyber Pakhtunkhwa, Pakistan.

Sher, H., Ahmad, A., Eleyemeni, M., Hadi, F., Sher, H., 2010. Impact of the nomadic grazing on medicinal plants diversity in Miandam, Swat-Pakistan. American-Eurasian Journal of Sustainable Agriculture 4, 152-159.

Shinwari, Z.K., 2010. Medicinal plants research in Pakistan. Journal of Medicinal Plants Research 4, 161-176.

Siddiqui, M.F., Ahmed, M., Wahab, M., Khan, N., Khan, M.U., Nazim, K., Hussain, S.S., 2009. Phytosociology of Pinus roxburghii Sargent (Chir Pine) in lesser Himalayan and Hindu Kush range of Pakistan. Pakistan Journal of Botany 41, 2357-2369.

Spies, T.A., 1998. Forest structure: A key to the ecosystem. Northwest Sci. 72, 34-39.

Srivastava, J., Lambert, J., Vietmeyer, N., 1996. Medicinal plants; an expanding role in development. The International Bank for Reconstruction and Development/ the World Bank. Washington, D.C.20433, USA.

Tahir, S. N. A., Rafique M., Alaamer, A.S., 2010. Biomass fuel burning and its implications: Deforestation and greenhouse gases emissions in Pakistan. Environmental Pollution 158, $2490-2495$.

Taverna, K., Robert, K.P., Laura, C.P., 2005. Long-term change in ground-layer vegetation of deciduous forests of the North Carolina Piedmont, USA. Journal of Ecology 93, 202-213.

Ticktin, T., 2004. The ecological implications of harvesting non-timber forest products. Journal of Applied Ecology 41, 11-21.

Vellend, M., Verheyen, K., Jacquemyn, H., Kolb, A., Van, C.H., Peterken, G., Hermy, M., 2006. Extinction debt of forest plants persists for more than a century following habitat fragmentation. Ecology 87, 542-548.

Waagen, W., 1872. Rough section showing the relation of the rocks near Mari (Murree) Punjab. Memoirs of the Geological Survey of India 5 (Part-I), 15-18.

Waseem, M., Mohammad, I., Khan, S., Haider, S., Hussain, S.K., 2005. Tourism and solid waste problem in Ayubia National Park, Pakistan (A case study, 2003-2004) (Report). Peshawar, Pakistan: WWF-P Nathiagali office. 
World Bank., 1997.Medicinal plants; Rescuing a global heritage. Washington, D.C.20433, USA. WWF-P (World Wide Fund for Nature - Pakistan)., 2004. People and plants - Pakistan: capacity building in ethnobotany applied to conservation and sustainable use of plant resources (Annual Progress Report 1999-2004). Peshawar, Pakistan: WWF-P Peshawar office.

Wyatt, J.L., Silman, M.R., 2010. Centuries-old logging legacy on spatial and temporal patterns in understory herb communities. Forest Ecology and Management 260, 116-124.

Yirdaw, E., 2001. Diversity of naturally regenerated native woody species in forest plantations in the Ethiopian highlands. New Forests 22, 159-177. 


\section{Chapter 2}

\section{DIVERSITY OF MEDICINAL PLANTS AMONG DIFFERENT FOREST-USE TYPES OF THE PAKISTANI HIMALAYA}

Muhammad Adnan \& Dirk Hölscher

(Under review at the journal of Economic Botany) 


\subsection{ABSTRACT}

Medicinal plants collected in Himalayan forests play a vital role in the livelihoods of regional rural societies and are also increasingly recognized at the international level. However, these forests are being heavily transformed by logging. Here we ask how forest transformation influences the diversity and composition of medicinal plants. In northwestern Pakistan, we studied old-growth forests, forests degraded by logging and re-growth forests. First, an approximate map indicating these forest types was established and then 15 study plots per forest type were randomly selected. A total of 59 medicinal plant species consisting of herbs and ferns was found, most of which occurred in the old-growth forest. Number of species was lowest in forest degraded by logging and intermediate in re-growth forest. Further, the most valuable species that include six Himalayan endemics, almost exclusively occurred in old-growth forest. The species composition and abundance of forest degraded by logging differed markedly from that of old-growth forest, while re-growth forest was somewhat more similar to old-growth forest. The density of medicinal plants positively correlated with tree canopy cover in old-growth forest and negatively in degraded forest, which indicates that species adapted to open conditions dominate in logged forest. Thus, old-growth forests are important as refuge for vulnerable endemics. Forest degraded by logging has the lowest diversity of relatively common medicinal plants. Forest re-growth may foster the re-appearance of certain medicinal species valuable to local livelihoods and as such promote acceptance for the forest expansion and medicinal plants conservation in the region.

Keywords: forest degradation, forest recovery, livelihood, similarity, non timber forest products

\subsection{INTRODUCTION}

The World Health Organization estimates that 70-95\% of people living in developing countries rely chiefly on traditional medicines for their primary healthcare needs (WHO, 2011). An estimated 53,000 plant species are used medicinally worldwide (Hamilton, 2004), and traditional medicines from such plants are widespread throughout the world and comprise practices based 
on beliefs and experiences that have been handed down from generation to generation (Akerele et al., 1991; Rai et al., 2000). Large quantities of medicinal plants are also commercially transported from rural areas in developing countries into regional and international urban centers through established marketing chains (Olsen, 2005). The world market for traditional medicine in 2008 was calculated to be worth US\$ 83 billion (WHO, 2011) and it is estimated that at least $25 \%$ of all modern medicines are derived, either directly or indirectly, from medicinal plants, primarily through the application of modern technology to traditional knowledge (WHO, 2011). There is, however, no reliable estimate for the number of medicinal plants that are globally threatened, with calculations ranging between 4,160 and 10,000 (Vorhies, 2000; Hamilton, 2004).

Medicinal plants can provide a significant source of income for rural people in developing countries, especially through the sale of wild harvested material, which contributes $15-30 \%$ of the total income of poorer households (Hamilton, 2004). Until recently, the importance of medicinal plants is increasingly recognized in the Himalayan region (Larsen et al., 2000; Olsen, 2005), and particularly from ecological, social and economic perspectives (Arnold and Pérez, 2001; Negi et al., 2011). Despite its significance to rural livelihoods, the abundance and diversity of understory medicinal plant species are also being threatened by changes in the structural attributes of the overstory in native old-growth forest as a result of degradation (Gilliam, 2007; Liira et al., 2007; Ticktin et al., 2007; Wyatt and Silman, 2010). Changes in the structure of Himalayan forests have been reported in many studies (Schickhoff, 1995; Kumar and Ram, 2005; Nath et al., 2005). These changes are mainly the result of anthropogenic activities in the forests that have resulted in degradation and deforestation, and also have raised conservation concerns. As an example, degradation in Himalayan forests has caused rapid declines in both diversity and abundance of understory species (Mishra et al., 2004). On the other hand, in other regions of the world, it has been reported that if degraded forest are allowed to re-grow, this may increase the probability of re-occurrence of understory species that had previously disappeared (Parrotta et al., 1997; Barbier et al., 2008). However, such studies are too scarce from Himalayan forests to be able to evaluate the extent to which forest degradation and subsequent forest regrowth bring about changes in the diversity of understory flora. 
In the mountainous region of Pakistan, local people collect around 600 medicinal plants (approximately $10 \%$ of the total reported plant species) to support their livelihoods (Shinwari, 2010). Most of these species are understory herbs and ferns. Pakistan, with a forest cover of $4.8 \%$ (Lubna, 2001), undergoes severe deforestation at a rate of $1.5 \%$ per year (FAO, 2005). At this rate, the current forest cover of the country may have already been reduced to approximately $4 \%$, which also has a negative effect on the associated ground flora. Another possible consequence of deforestation is the disastrous flood of 2010 that hit the country, and particularly in the northwest (Rodriguez, 2010), where our study was conducted. Thus, there is a need for the expansion of forest area. The objectives of our study included, 1) to compare the diversity of medicinal plants among various forest-use types, and 2) to assess the relationship between forest tree structural variables and diversity of medicinal plants.

\subsection{MATERIALS AND METHODS}

\subsubsection{Study area}

The study was carried out in the Khyber Pakhtunkhwa province, the former Northwest Frontier Province of Pakistan, which constitutes $40 \%$ of the country's forested area (Lubna, 2001). Forests cover $17 \%$ of the province (WWF-P, 2004) and stretch across the Himalayas, Hindu Kush and Karakurum mountain ranges. Covering an area of 3,312 ha, the Ayubia National Park (ANP) is one of 24 national parks in Pakistan and is situated between $33^{\circ}-01^{\prime}$ and $34^{\circ}-38^{\prime} \mathrm{N}$ latitude and $73^{\circ}-20^{\prime}$ and $73^{\circ}-30^{\prime}$ E longitude (Fig. 2.1b). The study covers the ANP and its surrounding forests, which together constitute 8,978 ha in area. The study area ranges from 1,220 $\mathrm{m}$ to $2,865 \mathrm{~m}$ in altitude, with Miranjani being the highest peak (Hussain, 2003), and lies within reach of the monsoon, resulting in a mean annual precipitation of $1,500 \mathrm{~mm}$. There is snow cover between November and March and the mean annual temperature is $12^{\circ} \mathrm{C}$ (WWF-P, 2004). Soils are often shallow and of a loamy texture. The natural vegetation in the study area is Himalayan moist forest (Aumeeruddy et al., 2004). The dominant tree species are Abies pindrow Royle, Cedrus deodara G. Don, Pinus roxburghii Sargent, Pinus wallichiana A.B. Jacks, Quercus 
incana Roxb and Taxus wallichiana Zacc (Shafiq, 2003). Approximately 50,000 people currently live in 12 villages around the ANP. The major ethnic groups of the area are Karalls and Abbasis (Hazaary-wall), who speak Hindku and/or Potohari.

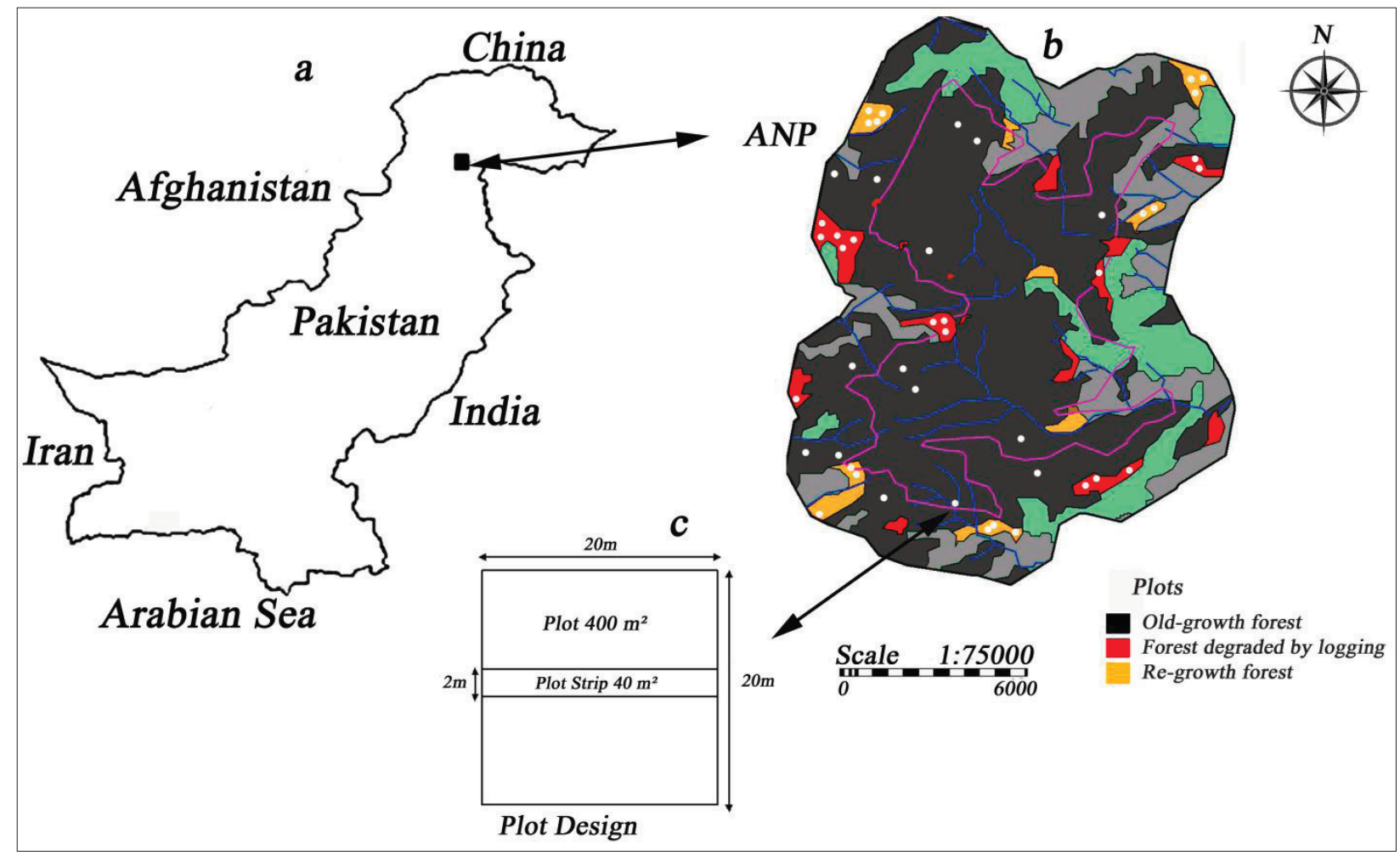

Figure 2.1 Map of the study area, forest-use types and plot design. (a) Pakistan and the location of the study region. (b) The study region with the Ayubia National Park (ANP) boundary, its surrounding forests (outside boundary) and randomly selected study plots in all forest-use types (dots). (c) Plot design; includes inventory plot for trees $\left(400 \mathrm{~m}^{2}\right)$ and plot strip for medicinal plants $\left(40 \mathrm{~m}^{2}\right)$.

\subsubsection{Forest-use types and plot selection}

For this study we selected three forest-use types: old-growth forest, forest degraded by logging and re-growth forest. Old-growth forest undergoes little or no human interference, whereas forest degraded by logging, apart from being partly cleared of trees, is exposed to little fodder collection but an over-collection of medicinal plants; however, this type of forest has been designated protection since 2008. Re-growth forest is composed of regenerated native species with little or no human interference for four to five decades. 
Field data is based on three steps. First of all, from July to October 2008 a reconnaissance survey was conducted for the identification of selected forest-use types and the development of a GIS based map (Fig. 2.1b). Fifteen study plots were randomly selected within each forest-use type on the GIS map within an altitudinal range of between 2,200 $\mathrm{m}$ and 2,400 $\mathrm{m}$ asl, out of a total area of 1,406 ha by using specific software (ILWIS, version 3.4) (ITC, 2007). The second step of the study was conducted between June and September 2009, in which field data on forest structure were collected from the selected plots. The third step of the study was conducted between August and September 2010 with a little survey on the diversity of medicinal plants.

\subsubsection{Medicinal plants and uses}

Medicinal plants include plants that are traditionally used for the treatment of various human diseases and in ethnoveterinary. We were accompanied by local collectors of medicinal plants who identified the plants by their local names. Species identification in the field was further assisted by a taxonomist from world wide fund for nature Pakistan (WWF-P). All studied medicinal plants were corrected for their botanical names, family names and publication authors according to the software Index Kewensis version 2.0 (1997). From the available literature and information by the collectors, we documented their local names, uses (Shafiq, 2003; WWF-P, 2004; Sher and Khan, 2006; Shinwari, 2010), reproduction status and light requirements (see Appendix) (Ali, 2011; Larkcom, 1997).

Most local names of medicinal plants are in two languages as Hindko (spoken in the study area) and Pashto (spoken in most parts of northwest Pakistan). Each plant has been either used for only one part or several parts such as leaves, whole plants, roots or tuber, stem, flowers and seeds or fruits. Almost all medicinal plant species have also a secondary use such as fodder, vegetables, insecticides, fruits, narcotics, cosmetics, handicraft, dye, tea and others (plant breeding, fish poison, shady, writing ink, bees attractant, spiritual). Medicinally these plants are used for curing diseases such as intestinal, stomach, fever, chest, inflammatory, skin, urinary, tonic, muscular, headache, teeth, ENT (ear, nose, throat), liver and spleen, insect and pests bites, 
eye, sexual, cardiac, pain, diabetes and anti cancerous (see Appendix) (Ibrar, 2003; Shafiq, 2003; WWF-P, 2004; Gillani et al., 2010).

Table 2.1 General attributes and tree stand structural characteristics of three forest-use types. Mean and standard error, $\mathrm{n}=15$ plots per forest-use type. Differing small letters indicate statistical differences $(\mathrm{p} \leq 0.05)$ in the Mann-Whitney test.

\begin{tabular}{llll}
\hline & $\begin{array}{l}\text { Old-growth } \\
\text { forest } \\
\text { Mean } \pm \mathrm{SE}\end{array}$ & $\begin{array}{l}\text { Forest degraded } \\
\text { by logging } \\
\text { Mean } \pm \mathrm{SE}\end{array}$ & $\begin{array}{l}\text { Re-growth } \\
\text { forest } \\
\text { Mean } \pm \mathrm{SE}\end{array}$ \\
\hline Study area (ha) within $2200-2400 \mathrm{~m}$ asl. & 915 & 279 & 212 \\
Altitude of study plots (m asl) & $2373 \pm 20$ & $2350 \pm 34$ & $2293 \pm 40$ \\
Distance from the nearest community $(\mathrm{km})$ & $3.2 \pm 0.5$ & $1.0 \pm 0.2$ & $1.7 \pm 0.2$ \\
Slope (mean) $(\%)$ & 35 & 18 & 26 \\
Northern aspect $(\%)$ & 40 & 47 & 60 \\
Total number of tree species $(\geq 10 \mathrm{~cm}$ dbh) & 15 & 6 & 12 \\
Stem density $\left(\geq 10 \mathrm{~cm}\right.$ dbh) $\left(\right.$ no $\left.\mathrm{ha}^{-1}\right)$ & $610 \pm 34 \mathrm{~b}$ & $183 \pm 29 \mathrm{c}$ & $750 \pm 53 \mathrm{a}$ \\
Basal area $\left(\mathrm{m}^{2}\right.$ ha $\left.^{-1}\right)$ & $48 \pm 2 \mathrm{a}$ & $12 \pm 1 \mathrm{c}$ & $20 \pm 1 \mathrm{~b}$ \\
Tree canopy cover $(\%)$ & $76 \pm 4 \mathrm{a}$ & $46 \pm 3 \mathrm{c}$ & $56 \pm 4 \mathrm{~b}$ \\
Tree species richness $\left(\right.$ no per $\left.400 \mathrm{~m}^{2}\right)$ & $3.1 \pm 0.3 \mathrm{a}$ & $1.9 \pm 0.2 \mathrm{~b}$ & $2.9 \pm 0.4 \mathrm{a}$ \\
Leaf area index $(\mathrm{LAI})$ & $4.7 \pm 0.4 \mathrm{a}$ & $1.8 \pm 0.3 \mathrm{c}$ & $3.0 \pm 0.2 \mathrm{~b}$ \\
Shannon index, trees $\left(\mathrm{H}^{\prime}\right)$ & $0.94 \pm 0.1 \mathrm{a}$ & $0.49 \pm 0.1 \mathrm{~b}$ & $0.74 \pm 0.1 \mathrm{ab}$ \\
Litter thickness $(\mathrm{cm})$ & $3.4 \pm 0.4 \mathrm{a}$ & $1.3 \pm 0.2 \mathrm{c}$ & $2.1 \pm 0.2 \mathrm{~b}$ \\
Litter cover $(\%)$ & $89 \pm 2 \mathrm{a}$ & $44 \pm 5 \mathrm{c}$ & $74 \pm 3 \mathrm{~b}$ \\
\hline
\end{tabular}

\subsubsection{Forest tree inventory and medicinal plants assessment}

For this study, plot design consisting of a tree inventory plot of $20 \times 20 \mathrm{~m}\left(400 \mathrm{~m}^{2}\right)$ for data collection on the studied forest stand structural variables. This has already been carried out in our previous study, in which we have studied only some selected medicinal plants from an earlier survey (Adnan and Hölscher, 2011). Forest stand structural variables are represented here as table 2.1. Within each inventory plot, there was a plot strip of $20 \times 2 \mathrm{~m}\left(40 \mathrm{~m}^{2}\right)$ for the assessment of medicinal plants in our current study (Fig. 2.1c). For medicinal plants, plant density, species richness and species frequency were studied. Each plot strip was subdivided into 10 quadrates of $4 \mathrm{~m}^{2}$ each. The density of each plant species was recorded by counting the number of individuals and the frequency of each medicinal plant was recorded as the percentage of plots that included the species. The estimations of medicinal plants density and frequency were carried out following the protocol outlined by Curtis and McIntosh (1951). Species 
richness, Shannon-Wiener diversity index $\mathrm{H}^{\prime}$ and Shannon evenness (Magurran, 2004) per plot strip were also derived for medicinal plants. The Jaccard abundance based similarity index (Chao et al. 2005) and the Sørensen similarity index based on species presence-absence (Magurran, 2004) were applied to quantify species turnover of medicinal plants within forest-use types. The Jaccard index was also applied to quantify similarity of given forest-use type with old-growth forest on the basis of medicinal plants abundance. Higher values of these indices correspond to higher similarity in species composition, lower beta diversity and lower species turnover (Chao et al., 2005). Species indicator values of medicinal plants were determined by combining their relative abundance and relative frequency values under each forest-use type. The prices of medicinal plant species were taken from the local market in Abbottabad city in 2010.

\subsubsection{Statistical analysis}

The Mann-Whitney test was applied to test differences in the mean values of medicinal plant variables among given forest-use types. It was also applied to test the difference in the mean similarity index values between the two forest-use types for their similarity with old-growth forest in medicinal plants. For a given forest-use type, Spearman correlation was performed between tree stand structural variables and medicinal plant variables. Across forest-use types, a detrended correspondence analysis (DCA) was used to identify the variables of forest tree stand structure most probably related to the densities of medicinal plants and to differentiate medicinal plant species in relation to their correlation with the axes. As such, the forest tree stand structural variables were standardized to ensure equal weight was attributed to each of the variables. Data on the density of medicinal plants were logarithmically transformed as DCA based on the assumption of normally distributed data. The Monte Carlo test at 1,000 permutations was applied to identify significant indicator medicinal plant species; indicated by “*” symbols under each forest-use type. DCA and Monte Carlo tests were carried out using PC-ORD (version 5.06) (McCune and Mefford, 1999). Data compilation, Mann-Whiteny tests, Jaccard abundance index, Sørensen similarity index and Spearman correlation were carried out using Microsoft Excel and SPSS (version 16.0) (SPSS Inc., 2007). 


\subsection{RESULTS}

\subsubsection{Comparison of medicinal plants diversity and abundance as a whole between forest-}

use types

A total number of 59 medicinal plant species (herbs and ferns) occurred on the study plots. The majority of the 41 species were perennial, with 13 being annual and five biennial. Twenty-nine species were used for their leaves and 20 species for their roots and tubers. In addition to medicinal uses, 24 plants were used as fodder followed by 11 as vegetables. Most of the medicinal plant species (28) were used to treat various intestinal diseases, followed by 21 for stomach diseases (see Appendix).

The majority of the medicinal plant species (55) occurred in old-growth forest, with the lowest number of 40 species growing in forest degraded by logging and intermediate number of 49 species growing under re-growth forest. The mean species richness of medicinal plants (18.1 per $40 \mathrm{~m}^{2}$ plot) in old-growth forest plots was almost two times higher than in forest degraded by logging (Table 2.2). For medicinal plant abundance, a significantly higher Jaccard similarity index with old-growth forest was recorded for re-growth forest $(0.34)$ than for forest degraded by logging (0.20) (Fig. 2.2).

Table 2.2 Overall diversity and density of medicinal plants in old-growth forest, forest degraded by logging and re-growth forest. Mean and standard error, $\mathrm{n}=15$ plots per forest-use type. Differing small letters indicate statistical differences $(\mathrm{p} \leq 0.05)$ in the Mann-Whitney test.

\begin{tabular}{llll}
\hline & $\begin{array}{l}\text { Old-growth } \\
\text { forest } \\
\text { Mean } \pm \mathrm{SE}\end{array}$ & $\begin{array}{l}\text { Forest degraded } \\
\text { by logging } \\
\text { Mean } \pm \mathrm{SE}\end{array}$ & $\begin{array}{l}\text { Re-growth } \\
\text { forest } \\
\text { Mean } \pm \mathrm{SE}\end{array}$ \\
\hline Total number of species & 55 & 40 & 49 \\
Density $\left(\right.$ no $\left.\mathrm{m}^{-2}\right)$ & $19.1 \pm 1.8 \mathrm{a}$ & $13.7 \pm 2.6 \mathrm{~b}$ & $20.0 \pm 3.1 \mathrm{a}$ \\
Species richness (no per $\left.40 \mathrm{~m}^{2} \mathrm{plot}\right)$ & $18.1 \pm 1.4 \mathrm{a}$ & $10.1 \pm 1.0 \mathrm{~b}$ & $15.3 \pm 1.4 \mathrm{a}$ \\
Shannon index $\left(\mathrm{H}^{\prime}\right)$ & $2.2 \pm 0.1 \mathrm{ab}$ & $1.8 \pm 0.2 \mathrm{~b}$ & $2.3 \pm 0.1 \mathrm{a}$ \\
Shannon Evenness $\left(\mathrm{E}_{\mathrm{H}}\right)$ & $0.77 \pm 0.02 \mathrm{~b}$ & $0.80 \pm 0.06 \mathrm{a}$ & $0.84 \pm 0.02 \mathrm{a}$ \\
Sørensen index & $0.42 \pm 0.03 \mathrm{a}$ & $0.29 \pm 0.03 \mathrm{c}$ & $0.38 \pm 0.03 \mathrm{~b}$ \\
Chao abundance based index & $0.48 \pm 0.04 \mathrm{a}$ & $0.24 \pm 0.03 \mathrm{c}$ & $0.32 \pm 0.04 \mathrm{~b}$ \\
\hline
\end{tabular}


The mean density of all medicinal plants $\left(20 \mathrm{~m}^{-2}\right)$ in re-growth forest plots was greater than that in forest degraded by logging $\left(13.7 \mathrm{~m}^{-2}\right)$. Similarly, the mean Shannon diversity index $\mathrm{H}^{`}$ on regrowth forest (2.3) was also significantly higher than forest degraded by logging (1.8). The mean Shannon evenness of medicinal plants under both re-growth forest (0.84) and forest degraded by logging (0.80) was significantly higher than in old-growth forest (0.77). Old-growth forest and re-growth forest showed no significant differences between them for mean species' density, richness or Shannon diversity index $\mathrm{H}^{\backslash}$ (Table 2.2).

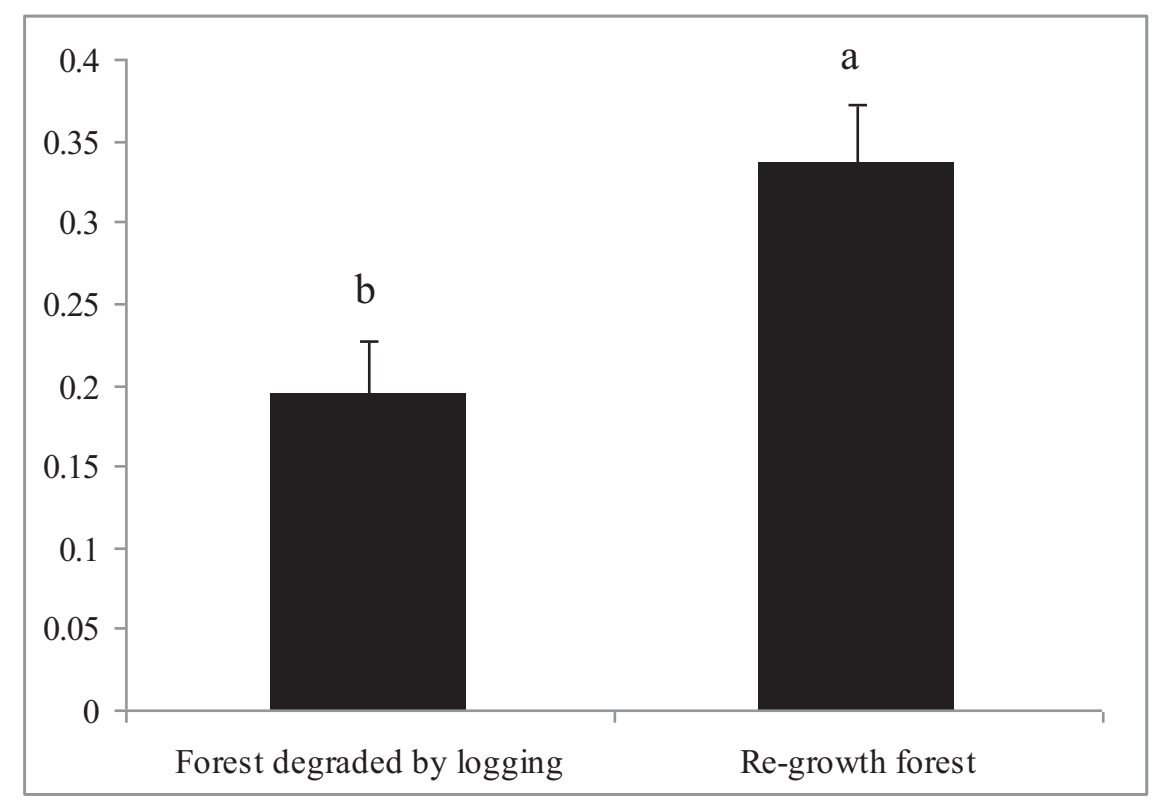

Figure 2.2 Similarity of forest-use types to old-growth forest for medicinal plants. Jaccard abundance based similarity index (Chao et al., 2005). Mean and standard error, $\mathrm{n}=15$ plots per forest-use type. Differing small letters indicate statistical difference $(p \leq 0.05)$ in the MannWhitney test.

Twenty species were identified as significant indicator species for given forest types, of which 14 were indicator species of old-growth forest, including species endemic to the Himalayan region such as Aconitum heterophyllum, Arum venosum, Coptis tecta, Impatiens bicolor, Paenonia emodi and Podophyllum emodi. Four species were indicator species of re-growth forest and only two were indicator species of forest degraded by logging. The local market prices of these medicinal plant species ranges between 0.2 and 9.0 USD kg ${ }^{-1}$ (Table 2.3). 


\subsubsection{Relationships between tree stand structure and medicinal plants}

Tree canopy cover under old-growth forest showed a significantly positive correlation with density of medicinal plants $(\mathrm{r}=0.69)(\mathrm{n}=15)$. However, tree canopy cover was significantly negatively correlated with the Shannon evenness of medicinal plants under old-growth forest $(\mathrm{r}=$ -0.58). In contrast, tree canopy cover under forest degraded by logging showed a significantly negative correlation with density of medicinal plants $(\mathrm{r}=-0.87)$. The Shannon $\mathrm{H}^{\backslash}$ of trees showed a significantly positive correlation with Shannon $H^{\prime}$ of all medicinal plants under each forest-use type (Table 2.4).

Table 2.3 Species indicator values of medicinal plant species under each forest-use type. "*” indicates significance of observed maximum indicator value for species (Monte Carlo test at 1,000 permutations). “-” indicates not available. Market prices are as per local market rate.

\begin{tabular}{lllll}
\hline Botanical name & $\begin{array}{l}\text { Market price } \\
\left(\mathrm{USD} \mathrm{Kg}^{-1}\right)\end{array}$ & $\begin{array}{l}\text { Indicator values (\%) } \\
\text { forest }\end{array}$ & $\begin{array}{l}\text { Forest degraded } \\
\text { by logging }\end{array}$ & $\begin{array}{l}\text { Re-growth } \\
\text { forest }\end{array}$ \\
\hline Aconitum heterophyllum & 7.0 & $33^{*}$ & - & - \\
Adiantum capillus-veneris & 1.5 & $33^{*}$ & - & - \\
Ajuga bracteosa & 3.0 & $33^{*}$ & - & - \\
Arum venosum & 1 & $33^{*}$ & - & - \\
Atropa acuminata & 2 & $38^{*}$ & - & - \\
Bergenia ciliata & 2.5 & $27^{*}$ & - & 5 \\
Coptis tecta & 2 & $31^{*}$ & - & - \\
Dryopteris ramosa & 1 & 1 & 3 & 14 \\
Foeniculum vulgare & 3.0 & 2 & $39^{*}$ & $30^{*}$ \\
Fragaria nubicola & 0.5 & 24 & 3 & 8 \\
Geranium wallichianum & 2 & $53^{*}$ & - & $46^{*}$ \\
Impatiens bicolor & 3.5 & $24^{*}$ & - & - \\
Paeonia emodi & 2.3 & $49^{*}$ & - & 1 \\
Podophyllum emodi & 4.5 & - & 10 & 4 \\
Silybum marianum & 0.5 & 1 & $38^{*}$ & $33^{*}$ \\
Trifolium repens & 0.2 & $33^{*}$ & - & 1 \\
Urtica dioica & 1.5 & $67^{*}$ & 1 & - \\
Valeriana jatamansi & 6.0 & 3 & - & 16 \\
Veronica laxa & 1 & $70^{*}$ & 1 & $31^{*}$ \\
Viola canescens & 9.0 & & & 18 \\
\hline
\end{tabular}


As indicated by the DCA on the 45 plots of three forest-use types, the axis-1 (eigenvalue $=0.36$ ) of forest stand structural data correlated with tree canopy cover $(\mathrm{r}=0.76)$ at $\mathrm{p}<0.01$. Of all medicinal plants, the density of 18 species showed positive correlations with axis 1 such as Valeriana jatamansi and Viola canescens. This shows that the densities of these medicinal plants increases with increasing tree canopy cover. The densities of eight medicinal plants showed negative correlations with axis 1 such as Chrysanthemum leucanthemum, Galium aparine and Trifolium repens, which implies that these species decrease with increasing tree canopy cover. The densities of 33 medicinal plants did not show any correlation with axis 1 such as Achillea millefolium, Agrimonia eupatoria and Gentiana kurroo, but they were canopy cover indifferent species (Fig. 2.3).

Table 2.4 Spearman correlation between medicinal plant variables and tree stand structural variables under each forest-use type $(\mathrm{n}=15)$; “*” indicates significant correlation at $\mathrm{p} \leq 0.05$ and “**” indicates higher significant correlation at $\mathrm{p} \leq 0.01 . \mathrm{ns}=$ no significant correlation.

\begin{tabular}{llllll}
\hline & & \multicolumn{4}{c}{ Medicinal plants } \\
\hline & & $\begin{array}{l}\text { Density } \\
\left(\mathrm{no} \mathrm{m}^{-2}\right)\end{array}$ & $\begin{array}{l}\text { Richness }(\mathrm{no} \\
\left.\text { per } 40 \mathrm{~m}^{2}\right)\end{array}$ & $\begin{array}{l}\text { Shannon } \\
\text { index }\left(\mathrm{H}^{\prime}\right)\end{array}$ & $\begin{array}{l}\text { Shannon } \\
\text { Evenness }\left(\mathrm{E}_{\mathrm{H}}\right)\end{array}$ \\
\hline $\begin{array}{l}\text { Old-growth } \\
\text { forest }\end{array}$ & Tree canopy cover $(\%)$ & $0.69^{* *}$ & $\mathrm{~ns}$ & $\mathrm{~ns}$ & $-0.58^{*}$ \\
Forest degraded & Shannon index, trees $\left(\mathrm{H}^{\prime}\right)$ & $\mathrm{ns}$ & $0.96^{* *}$ & $0.73^{* *}$ & $\mathrm{~ns}$ \\
by logging & Tree canopy cover $(\%)$ & $-0.87^{* *}$ & $\mathrm{~ns}$ & $\mathrm{~ns}$ & $-0.53^{*}$ \\
$\begin{array}{l}\text { Re-growth } \\
\text { forest }\end{array}$ & Shannon index, trees $\left(\mathrm{H}^{\prime}\right)$ & $\mathrm{ns}$ & $0.77^{* *}$ & $0.63^{*}$ & $\mathrm{~ns}$ \\
\hline & Tree canopy cover $(\%)$ & $\mathrm{ns}$ & $\mathrm{ns}$ & $\mathrm{ns}$ & $\mathrm{ns}$ \\
\hline
\end{tabular}

\subsection{DISCUSSION}

The study indicated variation in the diversity of understory medicinal plant species among studied forest-use types. In particular, old-growth forests had a higher diversity of medicinal plants compared to forests degraded by logging. Specie's density, species richness and Shannon diversity of medicinal plants were higher in old-growth forest than in forest degraded by logging. A higher density of medicinal plants was found in relation to higher tree canopy cover, while a higher diversity of medicinal plants were related to higher tree diversity under old-growth forest. These findings support other studies on Himalayan forests that indicate a higher diversity and 
abundance of understory plant species under undisturbed native forest compared to disturbed forest (Sundriyal and Sharma, 1996; Bhuyan et al., 2003; Uniyal et al., 2010). The effect of past land-use coupled with a more open canopy may explain the lower values of medicinal plant variables under forest degraded by logging in comparison to old-growth forest.

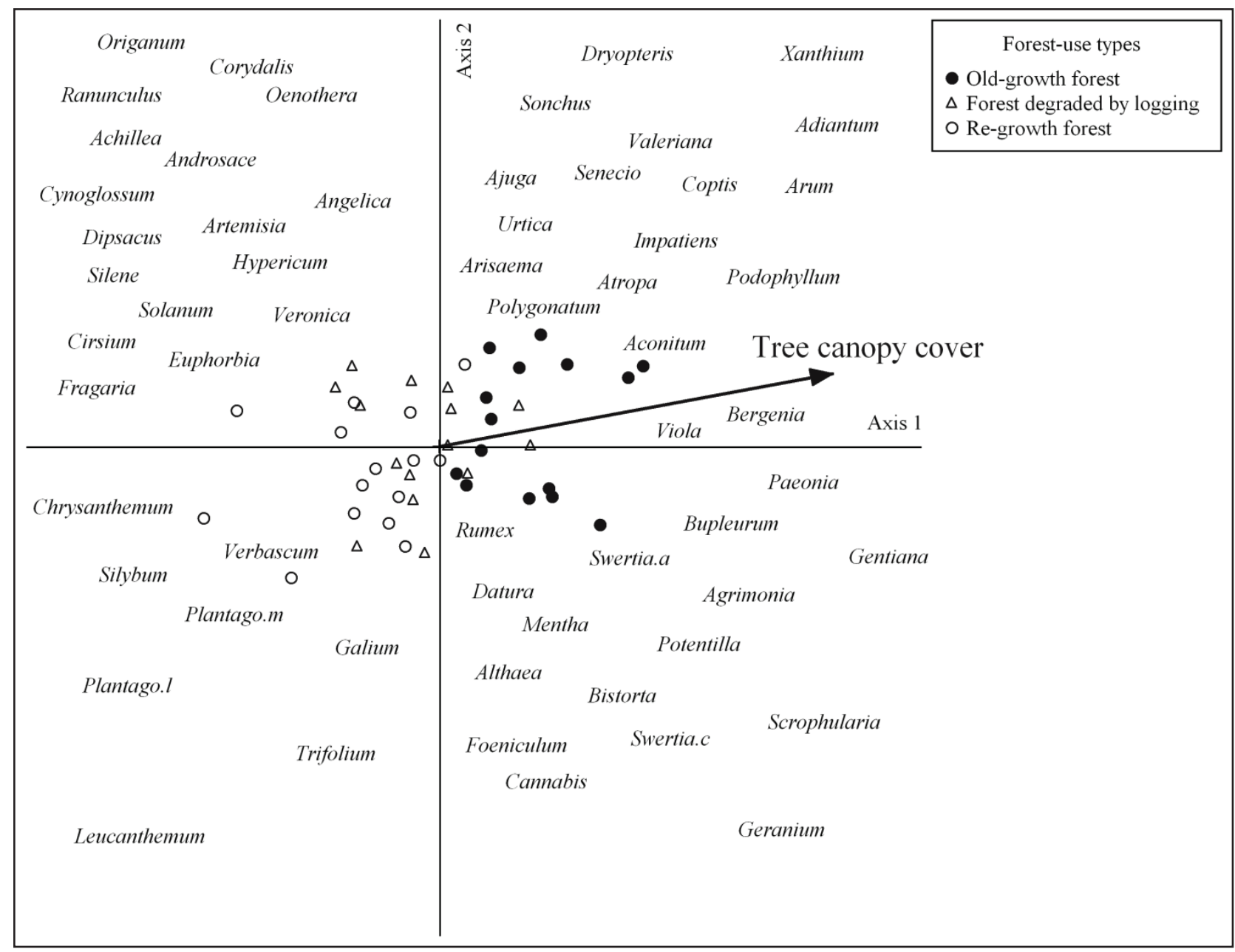

Figure 2.3 Detrended correspondence analysis (DCA) for the response of medicinal plant species densities to tree canopy cover in three forest-use types. Matrix consisted of 45 plots, 59 Medicinal plants and tree canopy cover. Axis 1: eigenvalue $=0.36$, explained variance $=31 \%$; Correlation threshold $\mathrm{r}^{2}>0.55$; Angle $=-20$ degrees; Vector scaling $=121$. Strong significant correlations (Spearman) at $\mathrm{p}<0.01$ have been observed for tree canopy cover $(\mathrm{r}=0.76)$ with axis-1. In Medicinal plants, 18 species showed positive correlation, eight species negative correlation and 33 showed no correlation with axis-1. Axis 2 provided little information and was therefore not included in the data set. Refer to appendix for complete botanical names of medicinal plants. 
Disturbed overstory has been proposed as one of the reasons for falls in diversity of plant species in the Khasi hills of Meghalaya, India (Mishra et al., 2004). In our study however, lower tree canopy cover was related to a higher density of medicinal plants under forest degraded by logging, most probably due to the presence of certain species adapted to sunny conditions.

Re-growth forest was found to be more diverse in comparison to forest degraded by logging. Studies have confirmed that if a forest is allowed to regenerate and is protected, the understory species that had once disappeared from it also regenerate (Parrotta et al., 1997; Islam et al., 2001; Keersmaeker et al., 2011). Forest re-growth alters conditions for the ground vegetation, such as soil fertility, light, temperature and moisture (Shankar et al., 1998; Carnevale and Montagnini, 2002; Barbier et al., 2008), all of which affect competition dynamics at ground level. In our study, a higher medicinal plant density and diversity was related to higher tree diversity under forest re-growth. Moreover, re-growth and old-growth forests had comparative medicinal plants variables, which were also likely found by Harrelson and Matlack (2006) in their study on Mesophytic old and young forest stands in southeastern Ohio, USA.

Medicinal plants under forest degraded by logging and re-growth forest were more evenly distributed than those under old-growth forest. Low evenness of species under old-growth forest might have resulted from high variations in the densities of medicinal plants that are adapted to various growing conditions. This is evident from our current study, where higher tree canopy cover resulted in low evenness of medicinal plants under old-growth forest. A study on Quercus leucotrichophora forest in the Garhwal Himalaya confirmed lower evenness of herb species under undisturbed forest than under highly disturbed forest (Uniyal et al., 2010).

Across forest-use types, higher tree canopy cover was associated with the increased abundance of certain medicinal plants. This particularly included the most valuable species such as Aconitum heterophyllum, Podophyllum emodi, Valeriana jatamansi and Viola canescens, which are also adapted to deep-shade conditions (Larkcom, 1997). The diversity of such medicinal plant species was found to be higher under old-growth forest in comparison to other forest-use types. This influence might be due to the natural effect of crown cover on the amount of 
available light for ground vegetation (Shanley and Luz, 2003). The abundant overstory can provide such habitat that can promote shade adapted understory species while suppressing sun adapted species (Balandier et al., 2006; Sharma et al., 2009).

The old-growth forests consisted of many species that are endemic to the Himalayan region. Studies have confirmed that nearly half of the plant population of the Himalayan region is endemic (Samant and Dhar, 1997; Kala, 2005). For example, Aconitum heterophyllum, an endemic species of northwestern Himalayas (Kala, 2005) that is critically endangered (Beigh et al., 2006), was only encountered in old-growth forest and was absent from forest degraded by logging and re-growth forests. Other species that were only found in old-growth forest, such as Arum venosum, Coptis tecta and Impatiens bicolor, are all endemic to the Himalayan region (Ali, 2011) and vulnerability of most of these species has already been suggested (WWF-P, 2004). The reasons for the occurrence of these plants only in old-growth forest may be manifold, but one could be that these plants are adapted to shady conditions (Larkcom, 1997). Moreover, regrowth forest and forest degraded by logging might lack the ability to provide a proper environment for the re-appearance of these species due to past anthropogenic factors. Certain species, such as Paeonia emodi and Podophyllum emodi, occurred only in old-growth and regrowth forests and are distributed throughout the Himalayas. These species have already been reported as highly vulnerable in the study area (WWF-P, 2004). Comparably shadier conditions than that of forest degraded by logging and about four decades of very little human interference may explain the re-appearance of such species under re-growth forest. There were some species that were only found in old-growth forest and forest degraded by logging, such as Gentiana kurroo. The reason as to why these species occurred in forest degraded by logging rather than in re-growth forest might be the closer proximity to old-growth forest.

In our study, low tree canopy cover appeared to favour species such as Galium aparine, species that are more commonly adapted to sunny conditions (Larkcom, 1997). The density of these species under re-growth forest and forest degraded by logging was higher than under old-growth forest, which might be due to the more open canopies in the former forest-use types. Some of these species only occurred in forest degraded by logging and re-growth forest, such as 
Chrysanthemum leucanthemum. Some species, such as Trifolium repens, are indicator species of forest degraded by logging and were observed in very low abundance and diversity under oldgrowth forest and re-growth forest. These species are, however, widely distributed in certain regions throughout Africa, America, Europe and the Himalayas, and along a wide altitudinal range (Ali, 2011).

Most medicinal plant species were observed to be indifferent to canopy cover, such as Achillea millefolium and Agrimonia eupatoria. The number of these species was observed to be higher under re-growth forest compared to forest degraded by logging. These species are either thought to tolerate partially shady conditions (Larkcom, 1997), or they may be influenced by any other variables.

The recorded medicinal plant species are valuable in terms of their traditional usage as medicine and other non timber forest products at local level. Moreover, about one third of medicinal plant species are economic resource species for local people, as indicated by the market prices higher or equal to $0.2 \mathrm{USD} \mathrm{kg}^{-1}$. Additionally, species such as Aconitum heterophyllum, Valeriana jatamansi and Viola canescens are also indicator species of old-growth forest and they occurred in higher abundance and frequency under this forest-use type. These species are traded along an established chain to the city markets for onward distribution and the demand of medicinal plants in Pakistan is increasing by $15 \%$ annually (Shinwari, 2010). For example, the total annual consumption of Aconitum heterophyllum increased sharply from $740 \mathrm{Kg}$ in 1980's (Williams and Ahmad, 1999) to around 10 tons in 2003, indicating around 13-fold increase in 20 years (Ibrar, 2003; Shiwnari, 2010). In ANP, the extraction of Aconitum heterophyllum has increased from 64 $\mathrm{Kg}$ in 2003 (Ibrar, 2003) to $500 \mathrm{Kg}$ in 2007, indicating eight-fold increase in four years. Hence, the absence of such species in re-growth forest and forest degraded by logging may lead towards degradation of old-growth forest.

Medicinal plants are important to rural people in the mountainous region of Pakistan both for domestic and commercial purposes. However, this important natural resource has become depleted in the logged forests, as evidenced by our study. In addition, forest degradation and 
deforestation in the country contributed to the severe devastation wrought by the disastrous flooding of 2010. As such, reforestation of the degraded areas has become a priority among local experts, not only to combat flood risk, but to also reverse losses of valuable flora important to the local economy. The promotion of natural forest succession on degraded land with the harvesting of medicinal plants by local populations may therefore represent a viable and more sustainable land-use policy direction for the future of the region.

In conclusion, old-growth forest is highly diverse in medicinal plants and plays an important role as refuge for the vulnerable endemics. Forest degraded by logging has the lowest diversity of medicinal plants and to a large extent the vegetation is composed of ubiquitous plants. If degraded areas are allowed to re-grow, they may foster the re-appearance of certain medicinal species valuable to local livelihoods and as such promote acceptance for the forest expansion and medicinal plants conservation in the region.

\subsection{ACKNOWLEDGMENTS}

This work was supported by the Kohat University of Science and Technology (KUST) under the higher education commission of Pakistan's (HEC) Human Resource Development program (HRD) by providing a grant to Muhammad Adnan; the authors are very thankful to the authorities of KUST and HEC for providing this financial support. The authors are also thankful to the World Wide Fund for Nature Pakistan (Peshawar region) team for their kind assistance during data collection.

\subsection{REFERENCES}

Adnan, M., Hölscher, D., 2011. Medicinal plants in old-growth, degraded and re-growth forests of NW Pakistan. Forest Ecology and Management 261, 2105-2114.

Akerele, O., Heywood, V., Synge, H., 1991. Conservation of medicinal plants. Cambridge University Press, New York. 
Ali, S.I., 2011. Flora of Pakistan. http://www.efloras.org/flora page.aspx?flora id=5; accessed on 07 May, 2011.

Arnold, J.E.M., Pérez, M.R., 2001. Can non-timber forest products match tropical forest conservation and development objectives? Ecological Economics 39, 437-447.

Aumeeruddy, T.Y., Shinwari, Z.K., Ayaz, A., Khan, A.A., 2004. Ethnobotany and management of fodder and fuelwood at Ayubia National Park, Northwest Frontier Province, Pakistan (People and plants working paper). International plants conservation unit, WWF-UK. www.peopleandplants.org/storage/working-papers/wp13.pdf; accessed on 20 July 2011

Balandier, P., Collet, C., Miller, J., Reynolds, P., Zedaker, S., 2006. Designing forest vegetation management strategies based on the mechanisms and dynamics of crop tree competition by neighbouring vegetation. Forestry 79, 3-27.

Barbier, S., Gosselin, F., Balandier, P., 2008. Influence of tree species on understory vegetation diversity and mechanisms involved-A critical review for temperate and boreal forests. Forest Ecology and Management 254, 1-15.

Beigh, S.Y., Nawchoo, I.A., Iqbal, M., 2006. Cultivation and conservation of Aconitum heterophyllum: A critically endangered medicinal herb of the northwest Himalayas. Journal of Herbs, Spices \& Medicinal Plants 11(4), 47-56.

Bhuyan, P., Khan, M.L., Tripathi, R.S., 2003. Tree diversity and population structure in undisturbed and human-impacted stands of tropical wet evergreen forest in Arunachal Pradesh, Eastern Himalayas, India. Biodiversity and Conservation 12, 1753-1773.

Carnevale, N.J., Montagnini, F., 2002. Facilitating regeneration of secondary forests with the use of mixed and pure plantations of indigenous tree species. Forest Ecology and Management $163,217-227$.

Chao, A., Chazdon, R.L., Colwell, R.K., Shen, T.J., 2005. A new statistical approach for assessing similarity of species composition with incidence and abundance data. Ecology Letters 8, 148-159.

Curtis, J.T., McIntosh, R.P., 1951. An upland forest continuum in the Prairie forest boarder region of Wisconsin. Ecology 32, 476-496.

FAO (Food and Agriculture Organization)., 2005. State of the world's forests-2005. Rome. 
Gillani, S.A., Fujii, Y., Shinwari, Z.K., Adnan, M., Kikuchi, A., Watanabe, K.N., 2010. Phytotoxic studies of medicinal plant species of Pakistan. Pakistan Journal of Botany 42, 987-996.

Gilliam, F.S., 2007. The ecological significance of the herbaceous layer in temperate forest ecosystems. Bioscience 57, 845-858.

Hamilton, A.C., 2004., Medicinal plants, conservation and livelihoods. Biodiversity and Conservation 13, 1477-1517.

Harrelson, S.M., Matlack, G.R., 2006. Influence of stand age and physical environment on the herb composition of second-growth forest, Strouds Run, Ohio, USA. Journal of Biogeography 33, 1139-1149.

Hussain, K., 2003. Impact of grazing on infiltration capacity of soil [report on Ayubia National Park]. World Wide Fund for Nature Pakistan, Peshawar.

Ibrar, M., 2003. Conservation of indigenous medicinal plants and their traditional knowledge found in moist temperate Himalayas Pakistan. Dissertation, Quaid-i-Azam University.

Islam, K.R., Ahmed, M.R., Bhuiyan, M.K., Badruddin, A., 2001. Deforestation effects on vegetative regeneration and soil quality in tropical semi-evergreen degraded and protected forests of Bangladesh. Land Degradation \& Development 12, 45-56.

Index Kewensis 2.0., 1997. On compact disc version 2.0 for the IBM PC. Oxford University Press, Oxford.

ITC (Faculty of Geo-Information Science and Earth Observation)., 2007. ILWIS (The integrated Land and Water Information System). http://www.itc.nl/ilwis; accessed on 10 October 2007.

Kala, C.P., 2005. Indigenous uses, population density, and conservation of threatened medicinal plants in protected areas of the Indian Himalayas. Conservation Biology 19, 368-378.

Keersmaeker, L.D., Vandekerkhove, K., Verstraeten, A., Baeten, L., Verschelde, P., Thomaes, A., Hermy, M., Verheyen, K., 2011. Clear-felling effects on colonization rates of shadetolerant forest herbs into a post-agricultural forest adjacent to ancient forest. Applied Vegetation Science 14, 75-83.

Kumar, A., Ram, J., 2005. Anthropogenic disturbances and plant biodiversity in forests of Uttaranchal, central Himalaya. Biodiversity and Conservation 14, 309-331. 
Larkcom, J., 1997. Plants for future: edible, medicinal and useful plants for healthier world. Permanent publication, UK. http://www.pfaf.org/user/default.aspx; accessed on 10 April, 2011.

Larsen, H.O., Olsen, C.S., Boon, T.E., 2000. The non-timber forest policy process in Nepal: actors, objectives and power. Forest Policy and Economics 1, 267-281.

Liira, J., Sepp, T., Parrest, O., 2007. The forest structure and ecosystem quality in conditions of anthropogenic disturbance along productivity gradient. Forest Ecology and Management $250,34-46$.

Lubna, H., 2001. Analyzing institutional set-up of forest management in Pakistan [Munich personal RePEc archive MPRA paper no. 7343]. mpra.ub.uni-muenchen.de/7343/.; accessed on 05 May 2011.

Magurran, A., 2004. Measuring biological diversity. Blackwell, London.

McCune, B., Mefford, M.J., 1999. PC-ORD, multivariate analysis of ecological data, version 5.01. MjM software, Gleneden Beach, Oregon.

Mishra, B.P., Tripathi, O.P,, Tripathi, R.S., Pandey, H.N., 2004. Effect of anthropogenic disturbance on plant diversity and community structure of a sacred grove in Meghalaya, northeast India. Biodiversity and Conservation 13, 421-436.

Nath, P., Arunachalam, A., Khan, M., Arunachalam, K., Barbhuiya, A., 2005. Vegetation analysis and tree population structure of tropical wet evergreen forests in and around Namdapha National Park, northeast India. Biodiversity and Conservation 14, 2109-2136.

Negi, V.S., Maikhuri, R.K., Rawat, L.S., 2011. Non-timber forest products (NTFPs): a viable option for biodiversity conservation and livelihood enhancement in central Himalaya. Biodiversity and Conservation 20, 545-559.

Olsen, C.S., 2005. Valuation of commercial central Himalayan medicinal plants. Ambio 34, $607-610$.

Parrotta, J.A., Turnbull, J.W., Jones, N., 1997. Catalyzing native forest regeneration on degraded tropical lands. Forest Ecology and Management 99, 1-7.

Rai, L.K., Prasad, P., Sharma, E., 2000. Conservation threats to some important medicinal plants of the Sikkim Himalaya. Biological Conservation 93, 27-33. 
Rodriguez, A., 2010. Pakistan flood crisis blamed partly on deforestation. Los Angeles Times October 13, 2010. http://articles.latimes.com/2010/oct/13/world/la-fg-pakistan-logging20101013; accessed on 31 August 2011.

Samant, S.S., Dhar, U., 1997. Diversity, endemism and economic potential of wild edible plants of Indian Himalaya. International Journal of Sustainable Development \& World Ecology 4, 179-191.

Schickhoff, U., 1995. Himalayan forest-cover changes in historical perspective: a case study in the Kaghan valley, northern Pakistan. Mountain Research and Development 15, 3-18.

Shafiq, C.M., 2003. Some aspect of bio-ecology of Ayubia National Park Northwest Frontier Province, Pakistan. Dissertation, University of Karachi.

Shankar, U., Lama, S.D., Bawa, K.S., 1998. Ecosystem reconstruction through 'taungya' plantations following commercial logging of a dry, mixed deciduous forest in Darjeeling Himalaya. Forest Ecology and Management 102, 131-142.

Shanley, P., Luz, L., 2003. The impacts of forest degradation non medicinal plant use and implications for health care in eastern Amazonia. Bioscience 53, 573-584.

Sharma, G., Nyutiyal, B.P., Nautiyal, A.R., 2009. Seedling emergence and survival in Cinnamomum tamala under varying micro-habitat conditions: conservation implications. Tropical Ecology 50, 201-209.

Sher, H., Khan, Z.D., 2006. Resource utilization for economic development and folk medicine among the tribal people; observation from northern part of Pakistan. Pakistan Journal of Plant Sciences 12, 149-162.

Shinwari, Z.K., 2010. Medicinal plants research in Pakistan. Journal of Medicinal Plants Research 4, 161-176.

SPSS Inc., 2007. SPSS version 16.0 for Windows, Chicago.

Sundriyal, R.C., Sharma, E., 1996. Anthropogenic pressure on tree structure and biomass in the temperate forest of Mamlay watershed in Sikkim. Forest Ecology and Management 81, $113-134$.

Ticktin, T., Fraiola, H., Whitehead, N., 2007. Non-timber forest product harvesting in aliendominated forests: effects of frond-harvest and rainfall on the demography of two native Hawaiian ferns. Biodiversity and Conservation 16, 1633-1651. 
Uniyal, P., Pokhriyal, P., Dasgupta, S., Bhatt, D., Todaria, N.P., 2010. Plant diversity in two forest types along the disturbance gradient in Dewalgarh watershed, Garhwal Himalaya. Current Science 98, 7-10.

Vorhies, F., 2000. The global dimension of threatened medicinal plants from a conservation point of view. In Honnef S, Melisch R (eds) Medicinal utilization of wild species: Challenge for man and nature in the new millennium. WWF Germany/TRAFFIC EuropeGermany, EXPO 2000, Hanover, pp. 26-29.

WHO (World Health Organization)., 2011. The world medicines situation 2011. Traditional Medicines: Global situation, issues and challenges. WHO press, Geneva, Switzerland. http://www.who.int/medicines/areas/policy/world_medicines_situation/WMS_ch18_wTrad itionalMed.pdf; accessed on 22 July 2011.

Williams, J.T., Ahmad, Z., 1999. Priorities for medicinal plants research and development in Pakistan. Medicinal and Aromatic Plants Program in Asia (MAPPA), New Delhi, IN. http://idl-bnc.idrc.ca/dspace/bitstream/10625/22721/1/110243.pdf; accessed on 17 August 2011.

WWF-P (World Wide Fund for Nature - Pakistan)., 2004. People and plants - Pakistan: capacity building in ethnobotany applied to conservation and sustainable use of plant resources [Annual Progress Report 1999-2004]. WWF-P Peshawar office, Peshawar.

Wyatt, J.L., Silman, M.R., 2010. Centuries-old logging legacy on spatial and temporal patterns in understory herb communities. Forest Ecology and Management 260, 116-124. 


\section{Chapter 3}

\section{MEDICINAL PLANTS IN OLD-GROWTH, DEGRADED AND RE-GROWTH FORESTS OF NW PAKISTAN}

Muhammad Adnan \& Dirk Hölscher

(Forest Ecology and Management, 2011, 261: 2105-2114) 


\subsection{ABSTRACT}

Many old-growth forest stands in northwest Pakistan have been structurally transformed as a consequence of logging, livestock grazing and tree re-growth. These forests are also used for gathering medicinal plants. The main objectives of our study were, 1) to assess differences in the structure of the tree layer and the abundance of medicinal plants among differently transformed forests, 2) to evaluate the recovery potential of medicinal plants under re-growth forests, and 3) to assess relationships between tree stand structural characteristics and the occurrence of medicinal plants. The first step of the study involved creating an approximate map covering an area of $90 \mathrm{~km}^{2}$ for five forest-use types (old-growth forest, forest degraded by logging, derived woodland, agroforest, re-growth forests). Next, 15 plots per forest-use type were randomly allocated at altitudes ranging from 2,200 $\mathrm{m}$ to $2,400 \mathrm{~m}$ asl, and the abundance of 10 medicinal herb species, which are easy to identify and significantly contribute to the livelihood of local people, was assessed therein. The study stands differed largely in tree basal area, which was highest in old-growth forest $\left(48 \mathrm{~m}^{2} \mathrm{ha}^{-1}\right)$, lowest in agroforest areas $\left(6 \mathrm{~m}^{2} \mathrm{ha}^{-1}\right)$ and intermediate in re-growth forest $\left(20 \mathrm{~m}^{2} \mathrm{ha}^{-1}\right)$. All ten medicinal plant species were encountered in old-growth and in re-growth forests but only five of these species also occurred on agroforest plots. The mean coverage of study medicinal plants was highest in old-growth forest (7\%), low in forest degraded by logging, derived woodland and agroforest ( 0.3 to $2 \%$ ), and intermediate in regrowth forest (4\%). The Jaccard abundance based similarity index indicates a considerable similarity (0.6) between re-growth and old growth forest for both trees and medicinal plants. The overall abundance of medicinal plants increased with increasing tree basal area and canopy cover. The abundance of some particular species decreased; however, the most sought-after medicinal species Bergenia ciliata, Valeriana jatamansi and Viola cancescens increased with tree basal area within specific forest-use type and also across forest-use types. In conclusion, our data suggest that anthropogenic forest degradation led to a reduction in the abundance of economically viable medicinal plants. It is further indicated that this can be reversed if degraded forests are allowed to regenerate.

Key words: non timber forest products, forest-use types, forest structure, livelihood 


\subsection{INTRODUCTION}

Forest structure is both a product and a driver of ecosystem processes and biological diversity, and if it changes due to natural or anthropogenic disturbances, there may be consequences for other forest components (Foster et al., 1997; Spies, 1998; Fuhrer, 2000; Parrotta et al., 2002). Common forms of anthropogenic and human induced disturbances involve logging, grazing, collection of non-timber forest products (NTFPs) and conversion of forest land to other forestuse types (García-Montiel and Scatena, 1994; Shanley and Luz, 2003). Such disturbances might affect the availability of certain commodities on which the people depend for their livelihoods such as timber, fuelwood and other NTFPs.

Understory medicinal plant species are an important component of NTFPs which play a vital role in providing subsistence and cash income to a large part of the world's population, particularly in developing countries (Hall and Bawa, 1993; Arnold and Ruiz, 2001; Hamilton, 2004). The understory species may be affected by structural changes in the native old-growth forest resulting from anthropogenic disturbances (Vellend, 2004; Liira et al., 2007; Wyatt and Silman, 2010). In many regions of the world, structural changes could be attributed to alterations in the overstory, which in turn influence understory densities, cover, frequencies and biomass (Taverna et al., 2005; Gilliam, 2007; D'Amato et al., 2009). Such changes in forest structure may even lead to local extinctions of certain species where changes in the forest structure persist over long periods of time (Vellend et al., 2006). On the other hand, re-growth forests protected from anthropogenic disturbance can encourage species recovery by promoting understory conditions suitable for ground vegetation (Parrotta et al., 1997; Barbier et al., 2008).

In Pakistan, people's dependence on forest resources has increased in the last few decades (Shinwari, 2010). Pakistan, with a forest cover of 4.8\% (Lubna, 2001), undergoes severe deforestation at a rate of $1.5 \%$ per year (FAO, 2005). People collect an estimated 600 species of medicinal plants as one of the major NTFPs (Shinwari, 2010). Around 10\% people are involved as primary occupation to medicinal plants marketing, while $30 \%$ are involved as subsidiary occupation to medicinal plants in the mountainous regions (Ahmad, 2003; Shinwari, 2010). Of 
these species, 500 are commonly used in traditional health care practices and 350 are traded for millions of US dollars on national and international markets (Ahmad, 2003). The forests of northwest Pakistan host the majority of traded medicinal plants (Shinwari, 2010) and these forests are subject to anthropogenic disturbances that have changed the structure of some nearnatural old-growth forests into various kinds of degraded forest-use types. However, questions remain as to how forest transformation changes the abundance of medicinal plants and whether the recovery of such species is possible under re-growth conditions in the Himalayan moist forests.

In 2010, Pakistan was struck by a disastrous flood. The reasons for such vulnerability have not yet been fully understood, but forest management discussions have included options such as a cessation of deforestation and forest degradation along with reforestation or natural forest regrowth (Khan 2010; Rodriguez, 2010; Shamsie, 2010). Given that forests of the region have traditionally served the livelihoods of local people by providing NTFP, the acceptance and, to some consequent extent, the success of forest extension will depend on whether NTFP, and in particular medicinal plants, are provided by the new forests.

This study was implemented in the Ayubia National Park (ANP) and its surroundings situated in northwest Pakistan, where local people use forests intensively for the collection of medicinal plants. In the region, many old-growth forest stands have been structurally transformed as a consequence of logging, livestock grazing and tree re-growth. The objectives of our study included, 1) to assess differences in the structure of the tree layer and the abundance of medicinal plants among differently transformed forests, 2) to evaluate the recovery potential of medicinal plants under re-growth forests, and 3) to assess relationships between tree stand structural characteristics and the occurrence of medicinal plants. 


\subsection{MATERIALS AND METHODS}

\subsubsection{Study area}

The study was carried out in the Khyber Pakhtunkhwa (KPK) province, the former Northwest Frontier Province of Pakistan, which constitutes $40 \%$ of the country's forested area (Lubna, 2001). Forests cover $17 \%$ of the province (WWF-P, 2004) and stretch across the Himalayas, Hindu Kush and Karakurum mountain ranges. Covering an area of 3,312 ha, the Ayubia National Park (ANP) is one of 21 national parks in Pakistan and is situated between $33^{\circ}-01^{\prime}$ to $34^{\circ}-38^{\prime} \mathrm{N}$ latitude and $73^{\circ}-20^{\prime}$ to $73^{\circ}-30^{\prime}$ E longitude (Fig. 3.1B). The study covers the ANP and its surrounding forests, which together constitute 8,978 ha in area. The study area ranges from 1,220 $\mathrm{m}$ to 2,865 $\mathrm{m}$ in altitude, with Miranjani being the highest peak (Hussain, 2003). The ANP and its surrounding forests lie within reach of the monsoon and have a mean annual precipitation of $1,500 \mathrm{~mm}$. There is snow cover between November and March and the mean annual temperature is $12{ }^{\circ} \mathrm{C}$ (WWF-P, 2004). Soils are often shallow and of a loamy texture. The natural vegetation in the area is Himalayan moist forest (Aumeeruddy et al., 2004). Around 410 species of combined vegetation have been reported consisting of 380 Spermatophytes, 16 species of Pteridophytes (Ferns), 9 Fungi and 5 Lichens. Spermatophytes are further divided into Gymnospermae (6 species) and Angiospermae (65 species of Monocotyledons and 309 species of Dicotyledons) (Shafiq, 2003). The dominant tree species are Abies pindrow Royel, Cedrus deodara G. Don, Pinus roxburghii Sargent, Pinus wallichiana A.B. Jacks, Quercus incana Roxb and Taxus wallichiana Zacc (Shafiq, 2003). Approximately 50,000 people currently live in 12 villages around the ANP. The major ethnic groups of the area are Karalls and Abbasis (Hazaarywall), who speak Hindku and or Potohari. Fuelwood consumption of each household in the study area has been estimated 11,000 kg/year dry weight (Hussain, 2003; Aumeeruddy et al., 2004) and 13 tons of fresh fodder is used per household every year (Rabia and Khan, 2004).

\subsubsection{Forest administration history and use}

The administration and management approach of the forests dates back to 1857 following British colonialisation when they were designated as "reserved" forests and "Guzara" forests. Reserved forests are defined as forests in which any human disturbance is prohibited, whereas Guzara 
forests are intended to meet domestic requirements (forest products) of local people. A part of the reserved forest was declared National Park in 1984 (Ayubia National Park, ANP) and the management was handed over to the KPK wildlife department. Guzara forests and reserve forest outside the ANP are administered by the KPK forest department (Farooque, 2002; WWF-P, 2004).

There are some complexities in the land tenure laws and the actual status of what is supposed to be Guzara forest is sometimes unclear to the local people. Most of the people do not know about their rights in Guzaras. The forests have also not been properly demarcated and in some cases, reserved forests in which the people have been granted rights are consequently treated as Guzaras. The free ranging of goats and other livestock coupled with fodder collection is currently being practiced in most of the Guzara forests. Degraded and deforested lands are more encountered within Guzara forest zones and some parts have also been reforested with native trees. Due to the rapidly rising population and associated increase in demand for forest services, some people have adopted illegal ways of exploiting resources from reserved forests and forests within the ANP (WWF-P, 2004).

\subsubsection{Forest-use types studied}

For this study, five forest-use types have been differentiated on the basis of forest structure, management, land tenure and resource utilization and classified according to the nomenclature proposed by Putz and Redford (2010):

'Old-growth forest' refers to the forest-use type with little or no human disturbances. It consists of many large diameter trees and the forest canopy is mainly closed. Old-growth forest can mainly be found in the ANP and in surrounding reserve forests and should consequently be afforded the highest level of protection from resource exploitation.

'Forest degraded by logging' refers to forest considerably affected by tree felling where many stumps can be found. It is found in both reserve and Guzara forests and has a relatively open canopy. Such identified areas have been protected from further anthropogenic use since two 
years. However, such open forest areas have supported livestock feed provision through grazing and, more commonly, fodder collection. In addition, the collection of valuable medicinal plants species was also common before the introduction of protection measures.

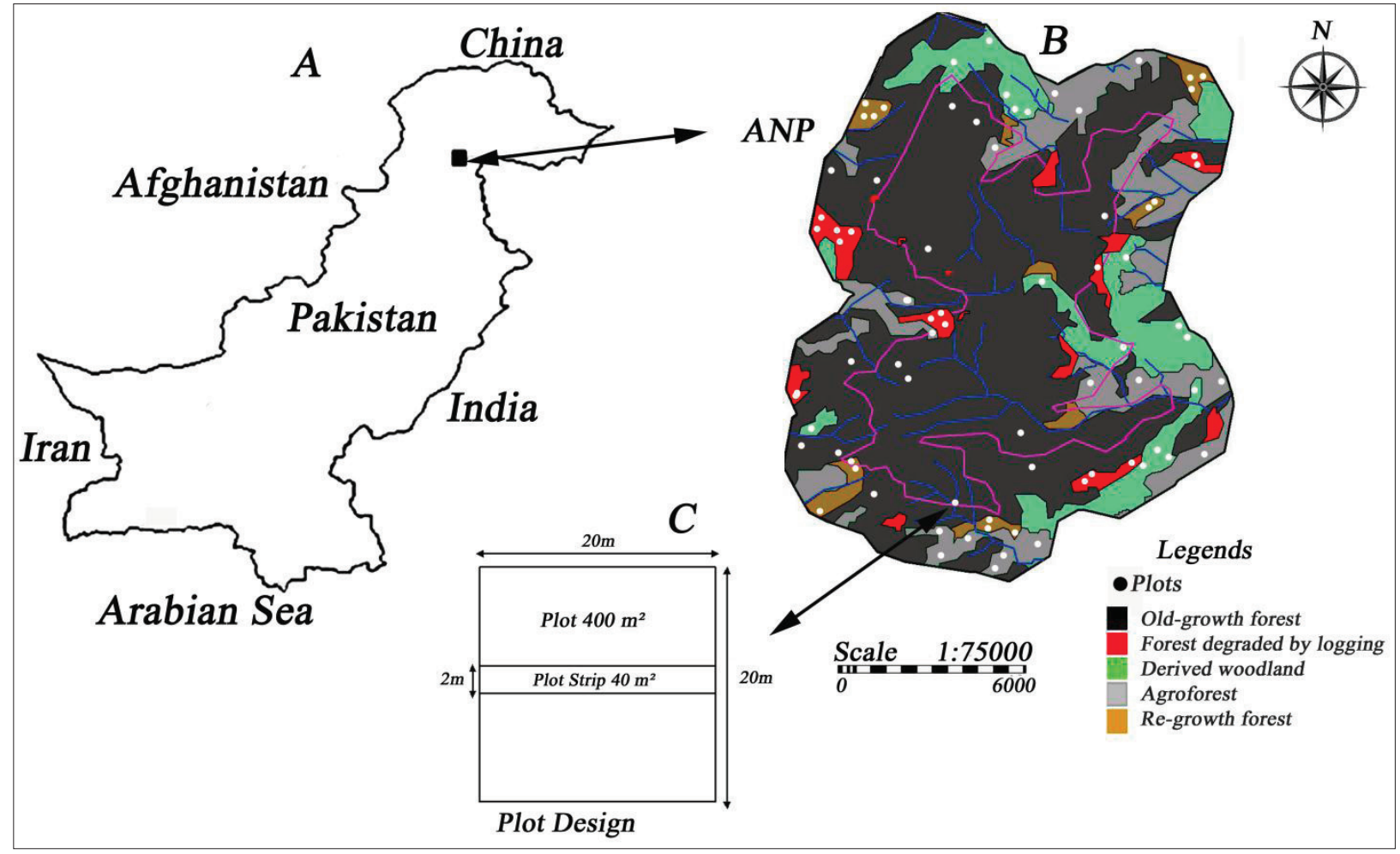

Figure 3.1 Map of the study area, forest-use types and plot design. (A) Pakistan and the location of the study region. (B) The study region with the Ayubia National Park (ANP) boundary, its surrounding forests (outside boundary) and randomly selected study plots in all forest types (dots). (C) Plot design; includes inventory plot for trees $\left(400 \mathrm{~m}^{2}\right)$ and plot strip for medicinal plants $\left(40 \mathrm{~m}^{2}\right)$.

'Derived woodland' refers to forest under high grazing pressure where people frequently collect fodder and medicinal plants. This forest-use type is generally close to villages and is mostly Guzara forest that contributes a major portion to the livestock fodder consumption. Legal and illegal logging has taken place in the recent past and still continues on a small scale. The regeneration of native trees is very limited due to grazing and collection activities coupled with coppicing. Large amounts of fodder, mainly grasses and herbaceous species, are collected by women from May to November each year (Rabia and Khan, 2004). 
'Agroforest' indicates areas of intense, long-term, cultivation where maize, potato, vegetables and some fodder species have been cultivated over the years. This land use type often represents former derived woodland and is more common on private land; however, due to the unclear land tenure system, some parts of Guzara lands have been encroached upon for the cultivation of agricultural crops, fruit trees such as peach, pears and apricots, fast growing tree species (Populus sp, Salix sp etc), other native trees (Pinus wallichiana, Ulmus wallichiana) and some grass species (Sorghum).

'Re-growth forests' are areas currently regenerating after heavy logging. They consist of many narrow diameter trees, have a high stem density and generally occur within reserve forests and the ANP. The existence of some remnant trees identifies these forest-use types as re-growth forests, as opposed to the secondary forest, as mentioned in Putz and Redford study (2010). Such forests have been free from logging for 20 to 50 years and, like old-growth forest, this forest-use type is also afforded some statutory protection.

Apart from these forest-use types, there are some reforested areas on formerly deforested and degraded land. The reforestations are however small in size and were assessed in a previous study (Adnan and Hölscher, 2010).

\subsubsection{Study sites and plot selection}

Field work was carried out in two steps. From July to October 2008 a reconnaissance survey was conducted for which the identification of selected forest-use types was based on information from WWF (World Wide Fund for Nature) Pakistan, the local population, relevant government and other non-governmental organizations and other available literature. WWF Pakistan was used as a primary source for the identification of these forest-use types because of their presence and interventions in several parts within our study area. Field visits were made to locate the boundaries of each studied forest-use type and GPS data were recorded, which resulted in an approximate map of forest-use types (Fig. 3.1B). Fifteen study plots were randomly selected within each forest-use type on the GIS map within an altitudinal range between 2,200 m and $2,400 \mathrm{~m}$ asl, out of a total area of 3107 ha. In order to select random sample points on the map 
we used specific software (ILWIS, version 3.4) (ITC, 2007), which selected two random values, one for the $\mathrm{X}$ axis and one for the $\mathrm{Y}$ axis, with the point of intersection representing the sample point. Each random point represented the center of each sample plot. The selected study plots had mainly northern aspects and lay on inclines ranging from 2-35\% (Table 3.1). The second step of the study was conducted between June and September 2009, in which field data on medicinal plant abundance and forest structure were collected from the selected plots.

\subsubsection{Medicinal plants}

Ten medicinal plant species were selected as target species for this study with the selection criteria being that they had a considerable market value and were relatively easy to identify in the field. The selected plants are used extensively in traditional medicine in the local area (Table 3.2). Bergenia ciliata (Haw) Stermb is used as a tonic and for the cure of various stomach diseases. Bistorta amplexicaulis (D. Don) Green is considered to be blood purifying (according to local traditional practitioners) and is used for curing ulcers. Geranium wallichianum D. Don is mainly used for the treatment of backache; Paeonia emodi Wall for back pain and as a tonic; Swertia chirata Buch Ham for stomachache and as a tonic; Gallium aparine L for jaundice; Podophyllum emodi Wall for liver disorders and as a tonic, and Plantago lanceolata L for diarrhea and stomach diseases. Valeriana jatamansi Jones and Viola canescens Wall ex Roxb are the two species with the highest market value for the local population and are used in the treatment of cholera and fever, respectively. Both species are considered shade adapted and mostly occur in association with trees (Adnan et al., 2010; Sher and Khan, 2006). Most of the above-mentioned plants can grow well under partial shaded conditions with the exception of Plantago lanceolata.

\subsubsection{Tree inventory and medicinal plant assessment}

Each plot consisted of a tree inventory plot of $20 \times 20 \mathrm{~m}\left(400 \mathrm{~m}^{2}\right)$ and a plot strip of $20 \times 2 \mathrm{~m}(40$ $\mathrm{m}^{2}$ ) within each inventory plot for the assessment of medicinal plants (Fig. 3.1C). Plots were laid down on the contour line and slope correction was applied. For trees with minimum $10 \mathrm{~cm}$ diameter at breast height, species identity, and diameter were recorded, and on the plot level basal area, species richness and stem density were assessed. An importance value for each tree 


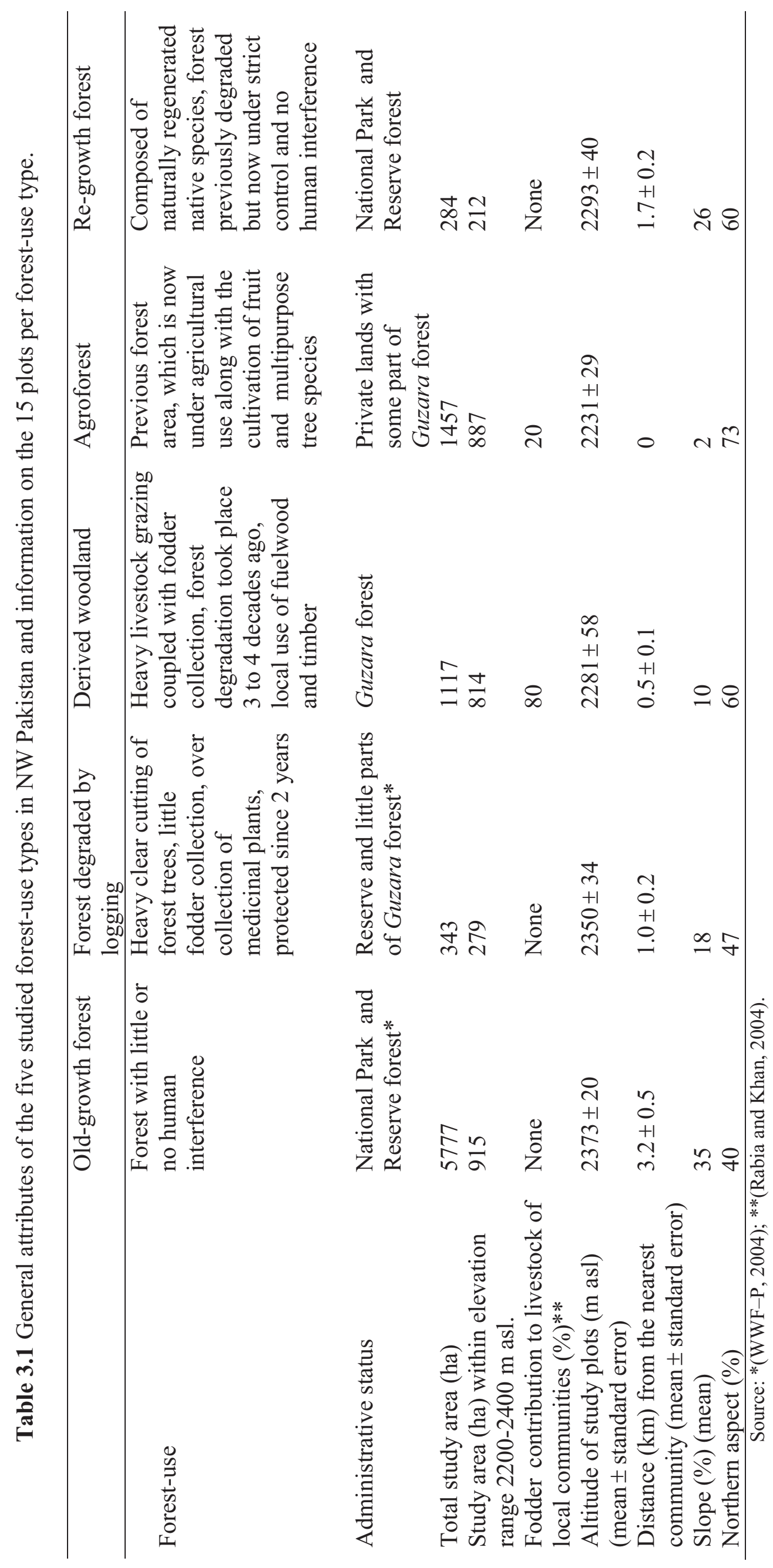




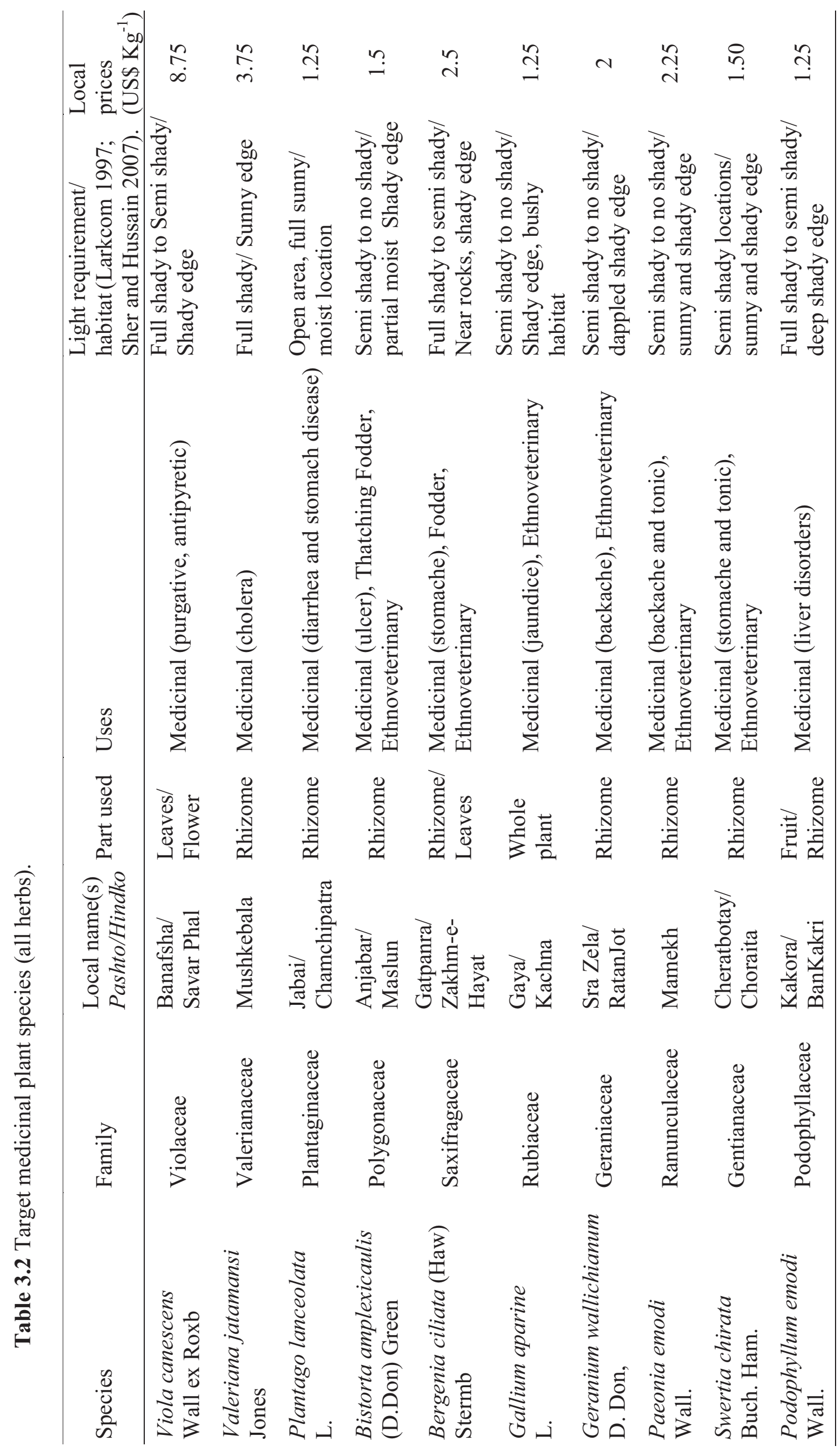


species within each forest-use type was assigned, which was estimated by summing relative density $\left(\mathrm{n} \mathrm{ha}^{-1}\right)$, relative dominance $\left(\mathrm{m}^{2} \mathrm{ha}^{-1}\right)$ and relative frequency $(\%$ of plots in which the species is present) in accordance with Curtis and McIntosh (1951). The Shannon-Wiener diversity index $\mathrm{H}^{\prime}$ (Magurran, 2004) of trees was calculated for each inventory plot. In addition, hemispherical photographs were taken along the plot middle line at $5 \mathrm{~m}, 10 \mathrm{~m}$ and $15 \mathrm{~m}$ with a high resolution digital camera (Minolta Dimage Xt, Japan). The camera had a $185^{\circ}$ fish-eye lens and was placed in a levelling device (Regent Instruments, Canada), which in turn was placed on top of a tripod. Images were analysed for canopy cover and leaf area index with CanEye 5.0 (INRA, 2007). Litter thickness per plot was measured in $\mathrm{cm}$ from the top of the litter layer to the underlying mineral soil. Data on litter cover was collected per plot through visual estimation as a percentage.

For medicinal plants, plant density, species richness, frequency, biomass and cover were studied. Each plot strip was subdivided into 10 quadrates of $4 \mathrm{~m}^{2}$ each. Data on percentage cover of each medicinal plant species was collected by visual estimation in percentage. The density of each plant species was recorded by counting the number of individuals. Similarly, species richness and Shannon-Wiener diversity index $\mathrm{H}^{\prime}$ per plot strip was derived for the target medicinal plant species. Frequency was calculated as the percentage of sub-plots that included the target species. The estimations of frequency, cover and density were carried out following the protocol outlined by Curtis and McIntosh (1951). Jaccard abundance based similarity index was applied to quantify the similarity of given forest-use types with old-growth forest on the basis of common tree and medicinal plant species (Chao et al., 2005). Mean biomass of a particular plant species (fresh/dry, above/below, $\mathrm{g} \mathrm{m}^{-2}$ ) per plot strip was estimated by selecting three plants close to three randomly selected points along the middle line and then multiplying their average weight (above or below) with the total number of plants of those particular species. The plant species were dried in shade for 15 to 30 days according to local methods and weighed to estimate dry biomass.

Local market value of a medicinal plant species from a given forest-use type was estimated by multiplying the standing dry weight above ground and or below ground biomass per hectare of 
that particular species estimated from the data with its sale price in US\$ taken from table 3.2. The prices of selected medicinal plant species were taken from the local market in 2008.

\subsubsection{Statistical analysis}

Kruskal-Wallis test was applied to test difference in the mean values of forest tree stand structural variables and medicinal plant variables among given forest-use types. Tests for medicinal plants were performed at both the whole and individual species level. Across forestuse types, Detrended Correspondence Analysis (DCA) was used to identify variables of forest tree stand structure probably related to the densities of medicinal plant. Therefore forest tree stand structure variables were standardized to ensure equal weight to all variables. Data on the density of medicinal plants were logarithmically transformed as DCA based on the assumption of normally distributed data. For a given forest-use type, Spearman correlation was performed between tree basal area and medicinal plant variables. Mann-Whitney test was applied to test the difference in the mean similarity index values of four forest-use types with old-growth forest in trees and medicinal plants. DCA was carried out using PC-ORD 5.06 (McCune and Mefford, 1999). Data compilation, Kruskal-Wallis tests, Jaccard abundance index and Spearman correlation were carried out using Microsoft Excel and SPSS version 16.0 (SPSS Inc., 2007).

\subsection{RESULTS}

\subsubsection{Stand structure and trees}

In total, 20 tree species with $\mathrm{dbh}>10 \mathrm{~cm}$ were recorded. Old-growth forests contained 15 species followed by agroforest with 14, re-growth forest with 12, derived woodland with 7 and forest degraded by logging with 6 species (Table 3.3). Pinus wallichiana was the most dominant tree species with the highest importance values on all forest-use types (see Appendix). The observed mean tree basal area on old-growth forest plots $\left(48 \mathrm{~m}^{2} \mathrm{ha}^{-1}\right)$ was 8 times higher than the lowest basal area recorded on agroforest plots $\left(6 \mathrm{~m}^{2} \mathrm{ha}^{-1}\right)$ (Table 3.3). Mean canopy cover of old-growth forest $(76 \%)$ was more than two times higher than those on agroforest plots $(33 \%)$. Stem density was highest in re-growth forests $\left(750 \mathrm{ha}^{-1}\right)$, which had attained a basal area of $20 \mathrm{~m}^{2} \mathrm{ha}^{-1}$ and a canopy cover of $56 \%$. Data suggest similarity index values between 0.56 to 0.67 for forest 
degraded by logging, derived woodland and re-growth forest with old-growth forest. However, agroforest (0.18) was found to have a significantly lower similarity index (Fig. 3.2A).

\subsubsection{Medicinal plants}

All 10 studied medicinal plant species occurred in old-growth and in re-growth forests (Table 3.4). Derived woodland consisted of 8 species, forest degraded by logging 7 species, and agroforest sites consisted of 5 species. Mean density of all medicinal plants $\left(14 \mathrm{ha}^{-1}\right)$ on oldgrowth forest plots was highest across forest-use types and was approximately 7 times higher than agroforest plots. Mean cover of medicinal plants (7\%) was 19 times higher on old-growth forest than agroforest. Mean density and cover of medicinal plants on re-growth forest was recorded second highest across forest-use types.

Most medicinal plant species showed higher densities on old-growth forest plots. In particular, the densities of Bergenia, Paeonia, Podophyllum, Viola and Valeriana on old-growth forest were the highest across forest-use types. Densities of these species were found to be second highest under re-growth forest. Bistorta, Geranium and Plantago were highest under re-growth forest (Table 3.5). Paeonia and Podophyllum were absent in forest degraded by logging, derived woodland, and agroforest sites but encountered under old-growth and re-growth forests.

For medicinal plant abundance, a significantly higher similarity index with old-growth forest was recorded for re-growth forest (0.56) than for other use types. Agroforest (0.20) showed the lowest similarity index value with old-growth forest in medicinal plant abundance (Fig. 3.2B). Data indicated that the increase in similarity index of other forest types with old-growth forest in trees was significantly very weak correlated $\left(n=60, r^{2}=0.08, p<0.05\right.$, slope 0.21$)$ with the increase in the similarity index of medicinal plants.

Total local market value of 10 species in old-growth forest is estimated at 3700 US dollars per hectare, which is much more than can be found in the other forest-use types (Table 3.6). This is largely influenced by the three most expensive species Bergenia, Viola and Valeriana, which 
particularly thrive in old-growth forest. However, as these species also occur in re-growth forest, this forest-use type ranks second with respect to possible income from marketable biomass.

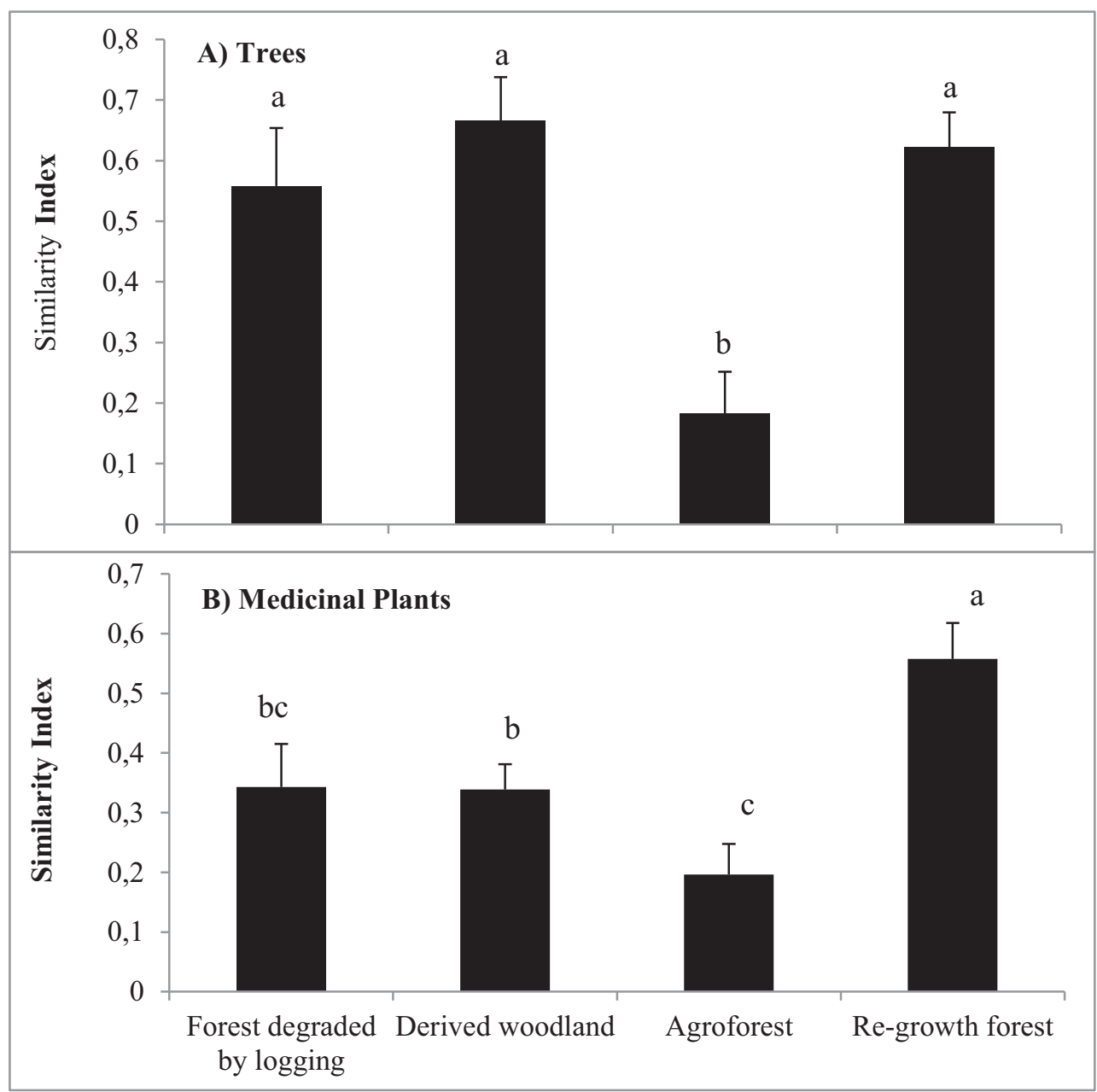

Figure 3.2 Similarity of forest-use types to old-growth forest for trees (A) and medicinal plants (B). Mean and standard error, $\mathrm{n}=15$ plots per forest-use type, $\mathrm{a}, \mathrm{b}$ and $\mathrm{c}$ indicates statistical difference (Mann-Whitney test).

\subsubsection{Relationships between tree stand structure and medicinal plants}

As indicated by the DCA on the 75 plots of five forest-use types, the axis-1 (eigenvalue $=0.38$ ) of forest stand structural data correlated with the basal area $(\mathrm{r}=0.72)$ and tree canopy $(\mathrm{r}=0.71)$ at $\mathrm{p} \leq 0.01$. For medicinal plants, axis 1 was observed at significantly higher positive correlation with the densities of Valeriana $(\mathrm{r}=0.76)$, Viola $(\mathrm{r}=0.73)$ and Bergenia $(\mathrm{r}=0.55)$. This shows that the densities of these medicinal plant species strongly increase with increasing tree basal 


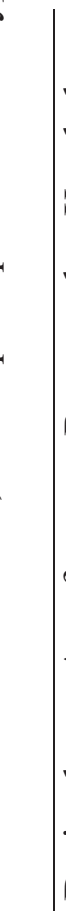

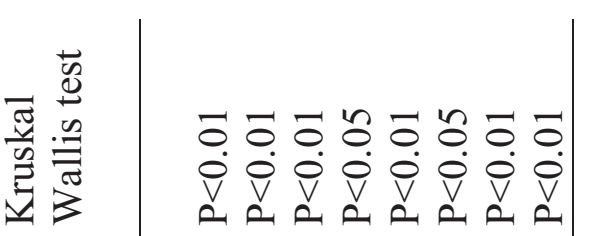

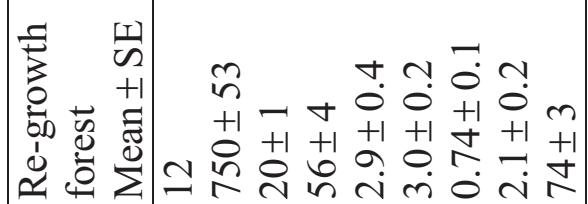

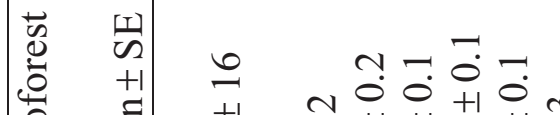

L.

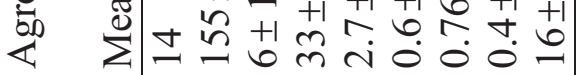

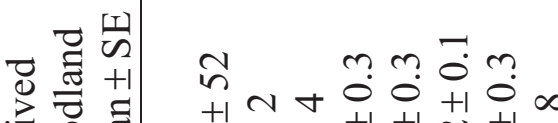

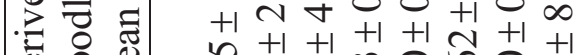

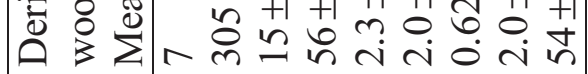

究

品

巳一

4

.气̊.?

.

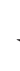

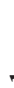

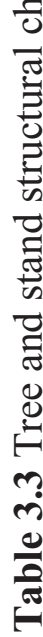

गे

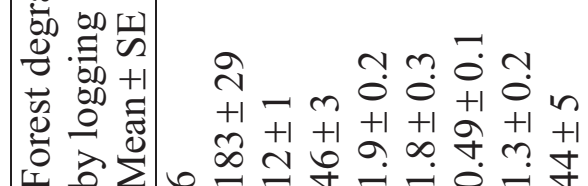

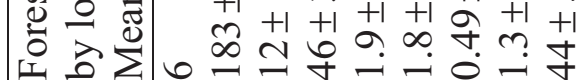

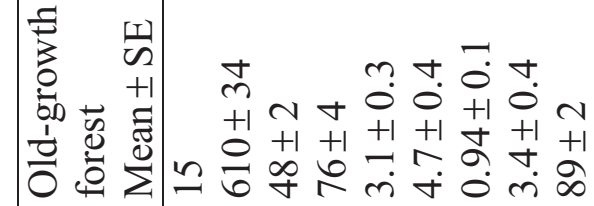

T⿱乛⿻

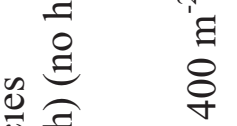

के

कू

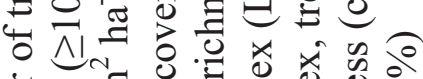

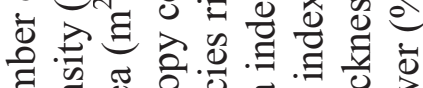

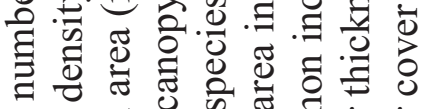

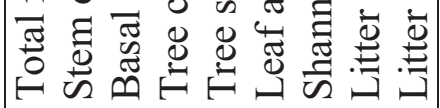

$\bar{c}$

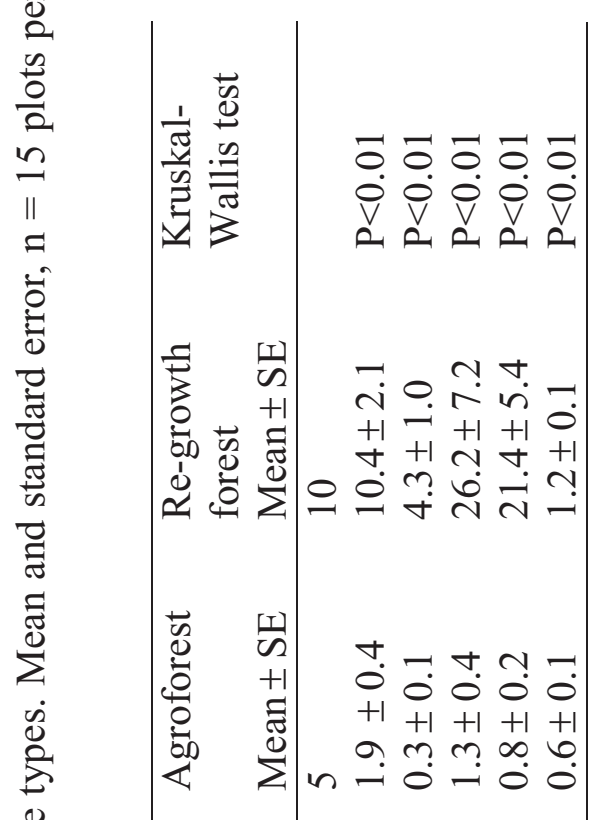

ڤ్

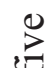

है

$\sum_{0}^{\infty}$

$\frac{0}{3}$

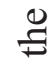

ธี

䒿

콣

뮴

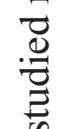

फ

홍

을

$>2$

ले

苟 


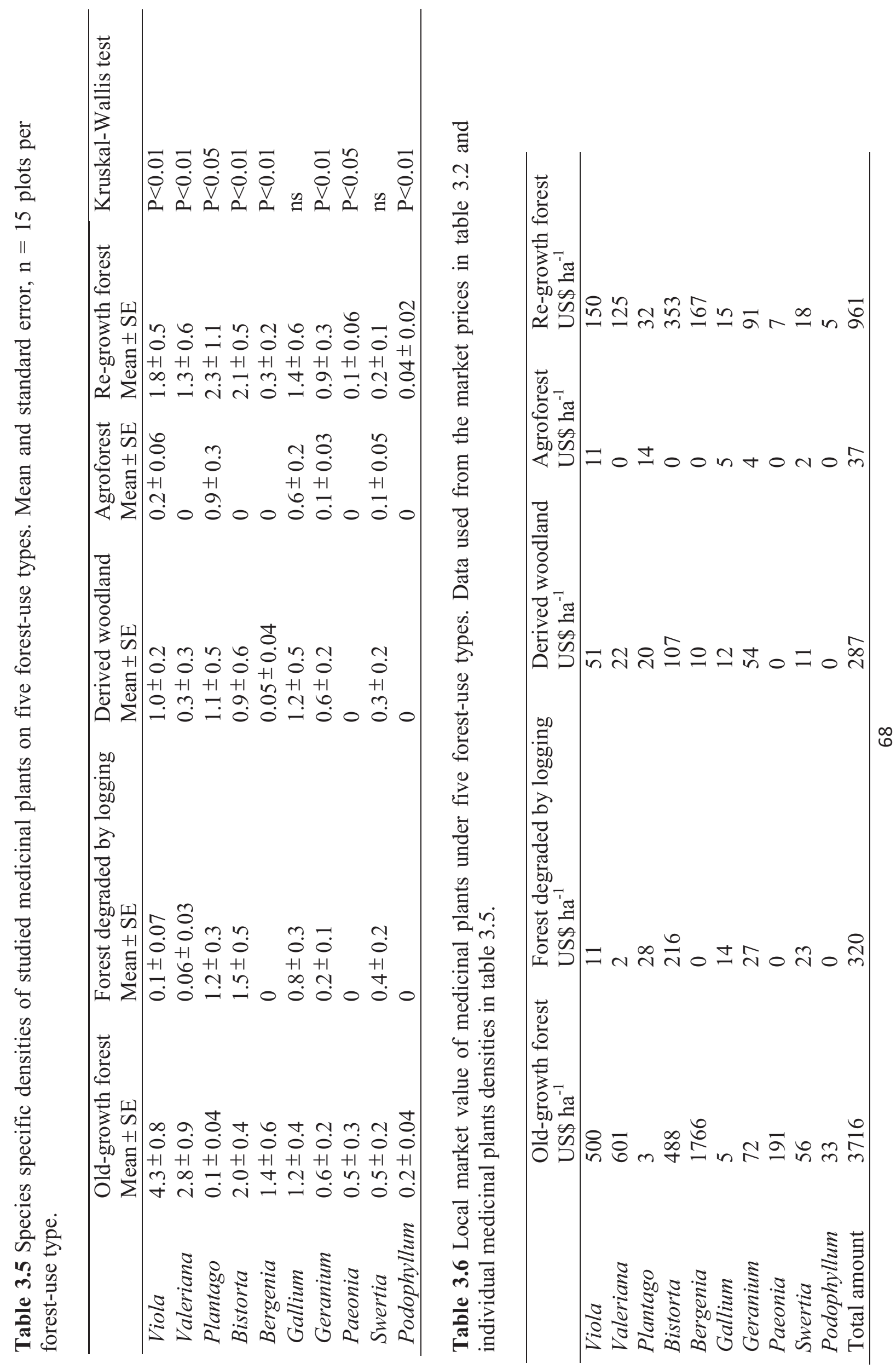


Table 3.7 Spearman correlation between medicinal plants densities with the basal area of trees under individual forest-use type $(\mathrm{n}=15)$ and across forest-use types $(\mathrm{n}=75)$; * indicates significant correlation at $\mathrm{p}<0.05$ and $* *$ higher significant correlation at $\mathrm{p}<0.01$ ). ns - no significant correlation. na - not available (species not found in this forest-use type).

\begin{tabular}{lllllll}
\hline & $\begin{array}{l}\text { Old-growth } \\
\text { forest } \\
(\mathrm{n}=15)\end{array}$ & $\begin{array}{l}\text { Forest degraded } \\
\text { by logging } \\
(\mathrm{n}=15)\end{array}$ & $\begin{array}{l}\text { Derived } \\
\text { woodland } \\
(\mathrm{n}=15)\end{array}$ & $\begin{array}{l}\text { Agroforest } \\
(\mathrm{n}=15)\end{array}$ & $\begin{array}{l}\text { Re-growth } \\
\text { forest } \\
(\mathrm{n}=15)\end{array}$ & $\begin{array}{l}\text { All } \\
\text { forest- } \\
\text { use types } \\
(\mathrm{n}=75)\end{array}$ \\
\hline Viola & $0.93^{* *}$ & $0.57^{*}$ & $\mathrm{~ns}$ & $\mathrm{~ns}$ & $0.65^{* *}$ & $0.68^{* *}$ \\
Valeriana & $0.95^{* *}$ & $0.63^{*}$ & $\mathrm{~ns}$ & $\mathrm{na}$ & $0.68^{* *}$ & $0.74^{* *}$ \\
Plantago & $-0.67^{* *}$ & $-0.70^{* *}$ & $-0.57^{*}$ & $-0.71^{* *}$ & $-0.72^{* *}$ & $-0.44^{* *}$ \\
Bistorta & $-0.71^{* *}$ & $-0.68^{* *}$ & $\mathrm{~ns}$ & $\mathrm{na}$ & $-0.55^{*}$ & $0.32^{* *}$ \\
Bergenia & $0.71^{* *}$ & $\mathrm{na}$ & $\mathrm{ns}$ & $\mathrm{na}$ & $0.62^{*}$ & $0.49^{* *}$ \\
Gallium & $-0.61^{*}$ & $-0.52^{*}$ & $-0.62^{*}$ & $-0.61^{*}$ & $-0.53^{*}$ & $-0.23^{*}$ \\
Geranium & $-0.58^{*}$ & $\mathrm{~ns}$ & $\mathrm{~ns}$ & $\mathrm{~ns}$ & $\mathrm{~ns}$ & $0.31^{* *}$ \\
Paeonia & $\mathrm{ns}$ & $\mathrm{na}$ & $\mathrm{na}$ & $\mathrm{na}$ & $\mathrm{ns}$ & $0.35^{* *}$ \\
Swertia & $-0.58^{*}$ & $0.61^{*}$ & $\mathrm{~ns}$ & $-0.63^{*}$ & $\mathrm{~ns}$ & $\mathrm{~ns}$ \\
Podophyllum & $0.56^{*}$ & $\mathrm{na}$ & $\mathrm{na}$ & $\mathrm{na}$ & $0.56^{*}$ & $0.57^{* *}$ \\
Viola & $\mathrm{ns}$ & $\mathrm{ns}$ & $-0.67^{* *}$ & $-0.67^{* *}$ & $\mathrm{~ns}$ & $0.47^{* *}$ \\
\hline
\end{tabular}

area and tree canopy cover. However, densities of Plantago $(\mathrm{r}=-0.73)$ and Gallium $(\mathrm{r}=-0.35)$ decreased with increasing tree basal area and tree canopy cover (Fig. 3.3).

In a given forest-use type, tree basal area under old-growth forest $(n=15)$ showed significantly positive correlation with densities of Valeriana $(\mathrm{r}=0.95)$ and Viola $(\mathrm{r}=0.93)$, and negative correlation with Bistorta $(\mathrm{r}=-0.71)$, Plantago $(\mathrm{r}=-0.67)$ and Gallium $(\mathrm{r}=-0.61)$. Similar correlation trends were also observed in re-growth forest and forest degraded by logging. However, in derived woodland and agroforest, basal area showed only negative correlations to certain species, such as Gallium and Plantago (Table 3.7).

\subsection{DISCUSSION}

The structure and composition of old-growth forests in this study are typical for the region, which have been described in the ANP management plan (Farooque, 2002). We encountered a total number of 15 tree species under old-growth forest in our study region. Forest degraded by logging was found to host only six tree species. This low value is most likely due to the 
overexploitation of preferred fuelwood species, such as Quercus dilatata and highly valuable timber species such as Cedrus deodara. Despite severe anthropogenic use, agroforest stands had the second highest number of tree species at 14 . This is mainly due to the cultivation of fruit trees and fast growing native tree species grown for fuelwood.

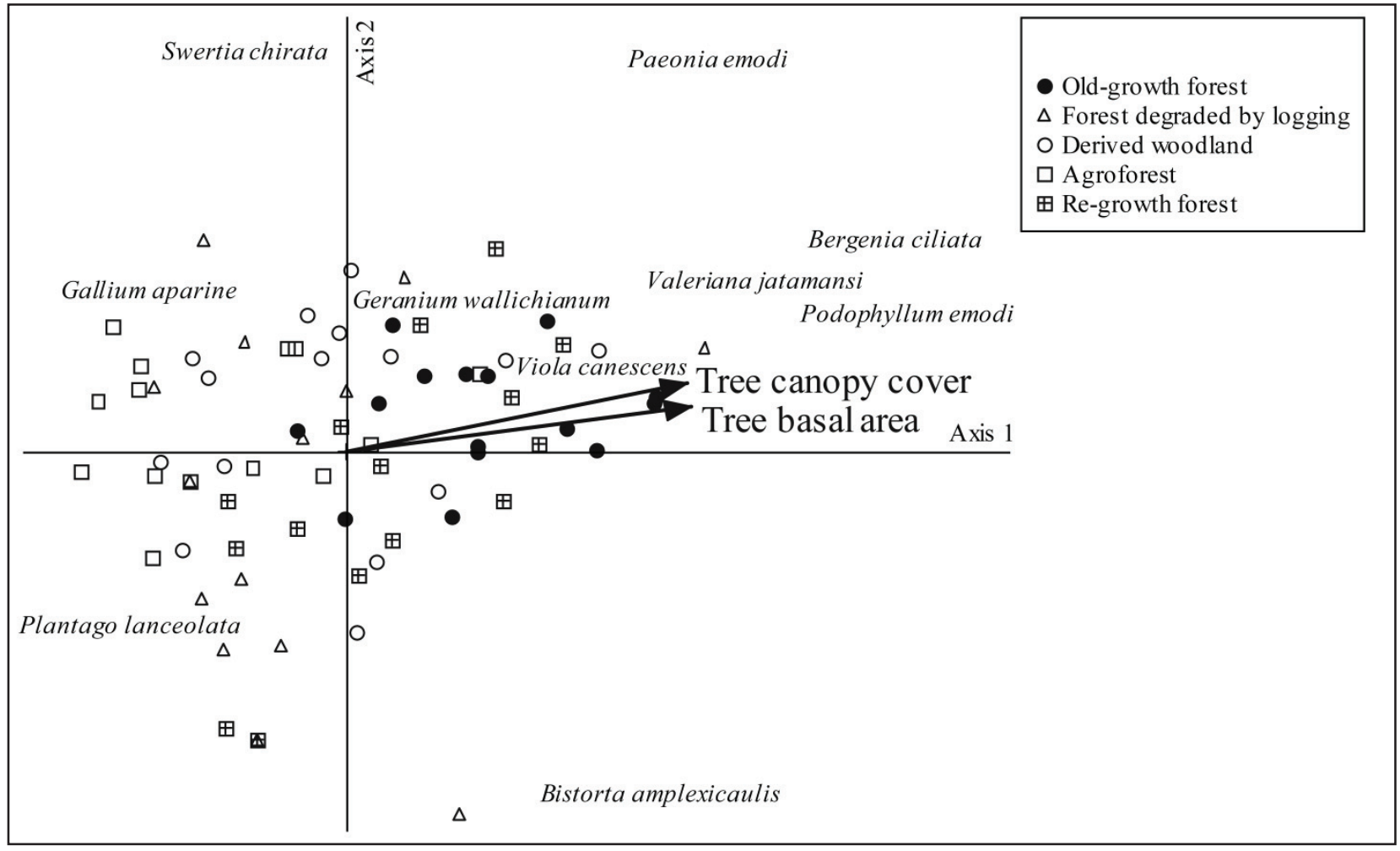

Figure 3.3 Detrended correspondence analysis (DCA) for the response of medicinal plant species densities to tree canopy cover and basal area on five forest-use types. Matrix consisted of 75 plots, 10 medicinal plant species, tree basal area and canopy cover. Axis 1: eigenvalue $=0.38$, explained variance $=33 \%$; Correlation threshold $\mathrm{r}^{2}>0.45$; Angle $=-20$ degree; Vector scaling 196. Significant correlations (Spearman) at $\mathrm{p}<0.01$ have been observed for basal area $(r=0.72)$ and tree canopy cover $(\mathrm{r}=0.71)$ with axis-1. In medicinal plants, higher significant correlation (Spearman) at $\mathrm{p}<0.01$ has been observed for $V$. jatamansi $(\mathrm{r}=0.76), V$. canescens $(\mathrm{r}=0.73), P$. lanceolata $(\mathrm{r}=-73)$, B. ciliata $(\mathrm{r}=0.55)$ and $G$. aparine $(\mathrm{r}=-0.35)$ with axis-1. Axis 2 gave little information and was therefore not included in the data set.

The basal area in our studied old-growth forest was in accordance with other little disturbed forests at this altitude in the Himalayas, which was found to range between $39 \mathrm{~m}^{2} \mathrm{ha}^{-1}$ and $56 \mathrm{~m}^{2}$ ha $^{-1}$ (Ahmed et al., 2006; Siddiqui et al., 2009). In our case, tree species richness and basal area was severely reduced on degraded sites, as was previously observed for the eastern Himalayas of 
Arunachal Pradesh, India (Bhuyan et al., 2003). Such severe declines are most likely due to intensive human disturbance, as evidenced in Namdapha National Park, northeast India, where Nath et al (2005) found a sharp decline in tree density and basal area with increasing disturbance magnitude. In our study, re-growth forest stands have been observed with higher quantities of tree structural variables, such as basal area and canopy cover, compared to anthropogenically disturbed forest land. Stem density under re-growth forest stands was found to be highest across forest-use types. A recent study in the Garhwal Himalaya, India indicated stem densities up to $850 \mathrm{ha}^{-1}$ under undisturbed naturally regenerated forest (Sharma et al., 2009). Our study also showed a high number of common tree species between re-growth and old-growth forest. Hence, re-growth forest may provide a starting point for ecological restoration.

All 10 studied medicinal plants considered collectively showed highest abundance in old-growth forest. This is in line with other observations from studies in the Himalayan region, which reported higher densities and ground flora richness under undisturbed sites than under highly disturbed sites (Bhuyan et al., 2003; Alyemeni and Sher, 2010; Uniyal et al., 2010). Similarly, D'Amato et al. (2009) indicated higher abundance, richness and diversity of understory species in old-growth forests compared to second-growth forests in hemlock forests in western Massachusetts. In contrast, some studies indicated lower abundance of ground flora under undisturbed abundant overstory in comparison to disturbed and more open overstories (Kumar and Ram, 2005; Nath et al., 2005; Rasingam and Parthasarathy, 2008). In these studies, ground species are taken as a whole when comparing disturbed with undisturbed forests; moreover, there are certain factors that can influence the comparison such as individual species characteristics and grazing pressure (Albrecht and McCarthy, 2009; Martin et al., 2009). There are however many other factors, which can alter the abundance of ground vegetation such as variation of a site type in tree canopy, tree basal area, age, temperature, amount of light reaching the forest floor, topography, soil pH and nutrients (Pitkänen, 2000; Shanley and Luz, 2003; Sher and Alyemeni, 2011).

In our study, Bergenia, Viola and Valeriana were most abundant in old-growth forest plots followed by re-growth forest plots, as such we consider these species to be shade adapted. 
Similarly, in a study in the Southern Ohio, USA, the abundance of four shade adapted forest herbs was higher under dense rather than less dense forest (Albrecht and McCarthy, 2009). In the same study, it was further argued that many shade adapted forest herbs are declining in abundance due to anthropogenic factors. In another study in the subtropical-temperate region of Uttarakhand, India, higher canopy cover in undisturbed forest emerged as the best micro-habitat for shade adapted species such as Cinnamomum tamala in comparison to disturbed forest (Sharma et al., 2009). In contrast, Plantago was observed less under old-growth forest sites, which might have been due to their better adaptation to growth conditions in less closed canopies, which was also observed in a study in the temperate Shola forest of Kerala, India with a lower abundance of light demanding herb species under closed canopies (Chandrashekara, 2006).

A key question remains as to whether ground flora can recover in re-growth forest. In our study, we found a higher density and cover of medicinal plants under re-growth forest than anthropogenically disturbed forest-use types. We found that species such as Bistorta and Geranium had higher densities on re-growth sites than that recorded for degraded forest sites, which could be because of partially shaded conditions under the former sites coupled with negligible amounts of anthropogenic disturbance. Low density species such as Paeonia and Podophyllum have also been found on re-growth forest that were not encountered on anthropogenically disturbed forest lands. Likewise, studies from different regions of the world suggest that species composition, cover and diversity of the herbaceous layer may recover if the area is protected from a particular set of disturbances (Parrotta, 1995; Roberts and Zhu, 2002). It was argued that this was driven by changes in understory microclimatic conditions, increased structural complexity of the stands and the development of litter and humus layers, all of which occur during the early years of tree re-growth (Parrotta et al., 1997). Forest re-growth changes many conditions for the ground vegetation, such as soil fertility, light, temperature, moisture (Shankar et al., 1998; Carnevale and Montagnini 2002; Barbier et al., 2008) all of which affect competition dynamics at ground level. However, for the first time for this region, our study documents that the decline in the abundance of medicinal plants due to forest degradation may be reversed if forest is allowed to re-grow. 
In our study, we have also observed that increase in the similarity of trees abundance across the four land use types with old-growth forest is weakly associated with the increase in the similarity of medicinal plants due to anthropogenicity. However, we observed some relations between tree stand structural characteristics and the abundance of selected medicinal plant species. Across forest-use types and individually under old-growth and re-growth forest-use types, higher tree basal area was associated with the increased abundance of most medicinal plants. This particularly included the three most valuable species Bergenia, Viola and Valeriana. On the other hand, low tree basal area appeared to be favoured by species such as Gallium and Plantago. This influence might be due to the significant correlation of stand basal area with crown cover, which can naturally affect the amount of available light for ground vegetation (Shanley and Luz, 2003). The abundant over-story can provide such habitat that can promote shade adapted under-story species while suppressing sun adapted species (Balandier et al., 2006; Sharma et al., 2009).

In our study region, NW Pakistan, the medicinal plants are harvested by locals in derived woodland and agroforest sites for domestic use as well as marketing purpose. Medicinal plants are usually traded along a well established marketing chain, which are finally consumed in a processed form in the major cities (Olsen, 2005). The market value of shade adapted medicinal plant species was higher than partial shade or sun adapted species and hence are more important for the livelihood of local people. As discussed, the abundance of shade adapted species such as Bergenia, Viola and Valeriana was significantly higher in old-growth forest than in other forestuse types. Hence, old-growth forests have higher economic value in terms of medicinal plant supply and can produce many times more income than the forest degraded by logging, derived woodland and agroforest. Because of their conservation status, today's old-growth forests and other protected forests are not open for the extraction of valuable medicinal plants. Nevertheless, extended degraded lands and degraded forest-use types exist in Pakistan's Himalayan region. It is concluded that forest degradation is the major reason for the decreased abundance of most valuable medicinal plants. Our study suggests that if forest re-growth is allowed on degraded areas in proximity to natural old-growth forest, one may also expect medicinal plants to come 
back, which will contribute to a greater valuation of such forests, particularly in terms of rural livelihoods. The promise of medicinal plant collection in newly established forest may consequently increase the acceptance of forest expansion by local people. Therefore, a sound operational and management strategy is suggested within the forest management plan of the area, which can ensure the re-growth of the degraded forests, sustainable use of medicinal plants under these forests and active participation of local people in the overall process.

\subsection{ACKNOWLEDGMENTS}

This work was supported by the Kohat University of Science and Technology (KUST) under the higher education commission of Pakistan's (HEC) Human Resource Development program (HRD) by providing a grant to Muhammad Adnan; the authors are very thankful to the authorities of KUST and HEC for providing this financial support. The authors are also thankful to the World Wide Fund for Nature Pakistan (Peshawar region) team for their kind assistance during data collection.

\subsection{REFERENCES}

Adnan, M., Hölscher, D., 2010. Medicinal plant abundance in degraded and reforested sites in northwest Pakistan. Mountain Research and Development 30, 25-32.

Adnan, M., Hussain, J., Shah, M.T., Shinwari, Z.K., Ullah, F., Bahader, A., Khan, N., Khan, A.L., Watanabe, T., 2010. Proximate and nutrient composition of medicinal plants of humid and sub-humid regions in Northwest Pakistan. Journal of Medicinal Plants Research 4, 339-345.

Ahmad, H., 2003. Capacity building for cultivation and sustainable harvesting of medicinal and aromatic plants. In: Ahmad H, Khan AA, editors. Proceeding of international workshop on conservation and sustainable uses of medicinal and aromatic plants in Pakistan, WWFPakistan. pp. 31-36. 
Ahmed, M., Husain, T., Sheikh, A.H., Sadruddin, H., Siddiqui, M.F., 2006. Phytosociology and structure of Himalayan forests from different climatic zones of Pakistan. Pakistan Journal of Botany 38, 361-383.

Albrecht, M.A., McCarthy, B.C., 2009. Seedling establishment shapes the distribution of shade adapted forest herbs across a topographical moisture gradient. Journal of Ecology 97, 1037-1049.

Alyemeni, M.N., Sher, H., 2010. Impact of human pressure on the population structure of Persicaria amplexicaule, Valeriana jatamansi and Viola serpens the naturally growing medicinal plants in Malam Jaba, Swat, Pakistan. Journal of Medicinal Plants Research 4, 2080-2091.

Arnold, J.E.M., Ruiz, P.M., 2001. Can non-timber forest products match tropical forest conservation and development objectives? Ecological Economics 39, 437-447.

Aumeeruddy, T.Y., Shinwari, Z.K., Ayaz., A., Khan, A.A., 2004. Ethnobotany and management of fodder and fuelwood at Ayubia National Park, Northwest Frontier Province, Pakistan (People and plants working paper). International plants conservation unit, WWF-UK. www.peopleandplants.org/storage/working-papers/wp13.pdf; accessed on 15 June 2010.

Balandier, P., Collet, C., Miller, J., Reynolds, P., Zedaker, S., 2006. Designing forest vegetation management strategies based on the mechanisms and dynamics of crop tree competition by neighbouring vegetation. Forestry 79, 3-27.

Barbier, S., Gosselin, F., Balandier, P., 2008. Influence of tree species on understory vegetation diversity and mechanisms involved-A critical review for temperate and boreal forests. Forest Ecology and Management 254, 1-15.

Bhuyan, P., Khan, M. L., Tripathi, R. S., 2003. Tree diversity and population structure in undisturbed and human-impacted stands of tropical wet evergreen forest in Arunachal Pradesh, Eastern Himalayas, India. Biodiversity and Conservation 12, 1753-1773.

Carnevale, N.J., Montagnini, F., 2002. Facilitating regeneration of secondary forests with the use of mixed and pure plantations of indigenous tree species. Forest Ecology and Management $163,217-227$.

Chandrashekara, U.M., 2006. Anthropogenic pressure on structure and composition of a Shola forest in Kerala, India. Journal of Mountain Science 3, 58-70. 
Chao, A., Chazdon, R.L., Colwell, R.K., Shen, T.J., 2005. A new statistical approach for assessing similarity of species composition with incidence and abundance data. Ecology Letters 8, 148-159.

Curtis, J.T., McIntosh, R.P., 1951. An upland forest continuum in the Prairie forest boarder region of Wisconsin. Ecology 32, 476-496.

D’Amato, A.W., Orwig, D.A., Foster, D.R., 2009. Understory vegetation in old-growth and second-growth Tsuga canadensis forests in western Massachusetts. Forest Ecology and Management 257, 1043-1052.

FAO (Food and Agriculture Organization)., 2005. State of the world's forests-2005. Rome, Italy. Farooque, M., 2002. Management Plan of Ayubia National Park 2002-2007. Natural resource conservation project, Galiat, Abbottabad.

Foster, D.R., Aber, J.D., Melillo, J.M., Bowden, R.D., Bazzaz, F.A., 1997. Forest response to disturbance and anthropogenic stress. Bioscience 47, 437-445.

Fuhrer, E., 2000. Forest functions, ecosystem stability and management. Forest Ecology and Management 132, 29-38.

García-Montiel, D.C., Scatena, F.N., 1994. The effect of human activity on the structure and composition of a tropical forest in Puerto Rico. Forest Ecology and Management 63, 5778.

Gilliam, F.S., 2007. The ecological significance of the herbaceous layer in temperate forest ecosystems. Bioscience 57, 845-858.

Hall, P., Bawa, K., 1993. Methods to assess the impact of extraction of non-timber tropical forest products on plant populations. Economic Botany 47, 234-247.

Hamilton, A.C., 2004. Medicinal plants, conservation and livelihoods. Biodiversity and Conservation $13,1477-1517$.

Hussain, K., 2003. Impact of grazing on infiltration capacity of soil (Report). Peshawar, Pakistan: WWF-P Peshawar office.

INRA, (French National Institute for Agricultural Research),, 2007. Can Eye software. www.avignon.inra.fr/can eye; accessed on 20 July 2008.

ITC (Faculty of Geo-Information Science and Earth Observation)., 2007. ILWIS (The integrated Land and Water Information System). http://www.itc.nl/ilwis; (accessed 10 October 2007) 
Khan, R.S., 2010. Chaotic and erratic monsoon, the-review. Dawn news August 22, 2010. http://dawnnews.tv/wps/wcm/connect/dawn-content-library/dawn/in-paper-magazine/thereview/chaotic-and-erratic-monsoon-280; accessed on 22 December 2010.

Kumar, A., Ram, J., 2005. Anthropogenic disturbances and plant biodiversity in forests of Uttaranchal, central Himalaya. Biodiversity and Conservation 14, 309-331.

Liira, J., Sepp, T., Parrest, O., 2007. The forest structure and ecosystem quality in conditions of anthropogenic disturbance along productivity gradient. Forest Ecology and Management $250(1-2) 34-46$

Lubna, H., 2001. Analyzing institutional set-up of forest management in Pakistan, Munich personal RePEc archive. MPRA paper no. 7343. mpra.ub.uni-muenchen.de/7343/; accessed on 14 March 2009.

Magurran, A.E., 2004. Measuring biological diversity. Oxford, United Kingdom: Blackwell Science.

Martin, P.H., Canham, C.D., Marks, P.L., 2009. Why forests appear resistant to exotic plant invasions: intentional introductions, stand dynamics, and the role of shade tolerance. Frontiers in Ecology and the Environment 7, 142-149.

McCune, B., Mefford, M.J., 1999. PC-ORD, multivariate analysis of ecological data, version 5.01. MjM software, Gleneden Beach, Oregon, USA.

Nath, P., Arunachalam, A., Khan, M., Arunachalam, K., Barbhuiya, A., 2005. Vegetation analysis and tree population structure of tropical wet evergreen forests in and around Namdapha National Park, northeast India. Biodiversity and Conservation 14, 2109-2135.

Olsen, C.S., 2005. Valuation of commercial central Himalayan medicinal plants. AMBIO 34, $607-610$.

Parrotta, J.A., Francis, J.K., Knowles, O.H., 2002. Harvesting intensity affects forest structure and composition in an upland Amazonian forest. Forest Ecology and Management 169, $243-255$.

Parrotta, J.A., Turnbull, J.W., Jones, N., 1997. Catalyzing native forest regeneration on degraded tropical lands. Forest Ecology and Management 99, 1-7. 
Parrotta, J.A., 1995. Influence of overstory composition on understory colonization by native species in plantations on a degraded tropical site. Journal of Vegetation Science 6, 627636.

Pitkänen, S., 2000. Effect of tree stand and site variables on alpha diversity of ground vegetation in the forests of Northern Karelia. Journal of Environmental Management 58, 289-295.

Putz, F.E., Redford, K.H., 2010. The importance of defining 'Forest': Tropical forest degradation, deforestation, long-term phase shifts, and future transitions. Biotropica 42, $10-20$.

Rabia, A., Khan, A.A., 2004. Medicinal plants of Ayubia National Park: prospective and constraints. In: Shinwari ZK, Watanabe T, editors. International Symposium on Medicinal Plants: Linkages Beyond National Boundaries. Proceedings 1. Vol 1. Islamabad, Pakistan: Pakistan Agriculture and Research Council, pp 153-161.

Rasingam, L., Parthasarathy, N., 2008. Diversity of understory plants in undisturbed and disturbed tropical lowland forests of little Andaman Island, India. Biodiversity and Conservation 18, 1045-1065.

Roberts, M.R., Zhu, L., 2002. Early response of the herbaceous layer to harvesting in a mixed coniferous-deciduous forest in New Brunswick, Canada. Forest Ecology and Management $155,17-31$.

Rodriguez, A., 2010. Pakistan flood crisis blamed partly on deforestation. Los Angeles Times October 13，2010. http://articles.latimes.com/2010/oct/13/world/la-fg-pakistan-logging20101013; accessed on 22 December 2010.

Shafiq, C.M., 2003. Some aspect of bio-ecology of Ayubia National Park Northwest Frontier Province, Pakistan (master thesis). Karachi, Pakistan: University of Karachi. http://prr.hec.gov.pk/Thesis/1008.pdf; accessed on 19 October, 2010.

Shamsie, K., 2010. Pakistan's floods are not just a natural disaster. The Guardian, 5 August 2010. http://www.guardian.co.uk/commentisfree/2010/aug/05/pakistan-floods-failure-state; accessed on 22 December 2010.

Shanley, P., Luz, L., 2003. The impacts of forest degradation non medicinal plant use and implications for health care in eastern Amazonia. Bioscience 53, 573-584. 
Shankar, U., Lama, S.D., Bawa, K.S., 1998. Ecosystem reconstruction through 'taungya' plantations following commercial logging of a dry, mixed deciduous forest in Darjeeling Himalaya. Forest Ecology and Management 102, 131-142.

Sharma, G., Nyutiyal, B.P., Nautiyal, A.R., 2009. Seedling emergence and survival in Cinnamomum tamala under varying micro-habitat conditions: conservation implications. Tropical Ecology 50, 201-209.

Sher, H., Alyemeni, M., 2011. Economically and ecologically important plant communities in high altitude coniferous forest of Malam Jabba, Swat, Pakistan. Saudi Journal of Biological Sciences 18, 53-61.

Sher, H., Khan, Z.D., 2006. Resource utilization for economic development and folk medicine among the tribal people; observation from northern part of Pakistan. Pakistan Journal of Plant Sciences 12, 149-162.

Shinwari, Z.K., 2010. Medicinal plants research in Pakistan. Journal of Medicinal Plants Research 4, 161-176.

Siddiqui, M.F., Ahmed, M., Wahab, M., Khan, N., Khan, M.U., Nazim, K., Hussain, S.S., 2009. Phytosociology of Pinus roxburghii Sargent (Chir Pine) in lesser Himalayan and Hindu Kush range of Pakistan. Pakistan Journal of Botany 41, 2357-2369.

Spies, T.A., 1998. Forest structure: A key to the ecosystem. Northwest Sci. 72, 34-39.

SPSS Inc., 2007. SPSS Version 16.0 for Windows, Chicago, IL, SPSS.

Taverna, K., Robert, K.P., Laura, C.P., 2005. Long-term change in ground-layer vegetation of deciduous forests of the North Carolina Piedmont, USA. Journal of Ecology 93, 202-213.

Uniyal, P., Pokhriyal, P., Dasgupta, S., Bhatt, D., Todaria, N.P., 2010. Plant diversity in two forest types along the disturbance gradient in Dewalgarh watershed, Garhwal Himalaya. Current Science 98, 7, 10.

Vellend, M., Verheyen, K., Jacquemyn, H., Kolb, A., Van, C.H., Peterken, G., Hermy, M., 2006. Extinction debt of forest plants persists for more than a century following habitat fragmentation. Ecology 87, 542-548.

Vellend, M., 2004. Parallel effects of land-use history on species diversity and genetic diversity of forest herbs. Ecology 85, 3043-3055. 
WWF-P (World Wide Fund for Nature - Pakistan)., 2004. People and plants - Pakistan: capacity building in ethnobotany applied to conservation and sustainable use of plant resources (Annual Progress Report 1999-2004). Peshawar, Pakistan: WWF-P Peshawar office.

Wyatt, J.L., Silman, M.R., 2010. Centuries-old logging legacy on spatial and temporal patterns in understory herb communities. Forest Ecology and Management 260, 116-124. 


\section{Chapter 4}

\section{MEDICINAL PLANT ABUNDANCE IN DEGRADED AND REFORESTED SITES IN NORTHWEST PAKISTAN}

Muhammad Adnan \& Dirk Hölscher

(Mountain Research and Development, 2010, 30: 25-32) 


\subsection{ABSTRACT}

Forest resources in Northwest Pakistan are under severe threat, which in turn negatively affect local people who aim to meet their subsistence needs by different forest-uses. Among forest-uses such as fodder and fuelwood, medicinal plant collection also play an important role in the livelihood of local people. To reduce pressure and dependency on remaining old growth forests, some deforested and degraded sites have been reforested. The objectives of the study are (i) to compare the abundance of medicinal plants between reforested and formerly forested degraded land and (ii) to assess the influence of reforested stand characteristics on the abundance of medicinal plants. Five plots have randomly been selected per land use type. On these plots we analyzed the abundance and other variables of ten herbal medicinal plants common and important for the rural human population. Frequencies, densities and cover of the ten medicinal plants were significantly higher on reforested sites compared to degraded sites. Frequencies of highly valuable species such as Valeriana jatamansi, Bergenia ciliata and Paeonia emodi were increased sixteen-, eight- and six-fold on reforested sites respectively. Moreover, density, cover and diversity of medicinal plants (in total) were seven, five and two times higher respectively, and three species which were absent from degraded sites were encountered on reforested sites. On reforested plots, tree basal area was the most influential variable positively correlated with the abundance of the aforementioned species. Thus, our data suggests that reforestation of degraded sites can strongly increase the abundance of medicinal plants and may be an instrument of improving the livelihood of local people and protect remaining natural forest resources.

Keywords: basal area, degraded land, livelihood, non-timber forest products, tree plantations

\subsection{INTRODUCTION}

Degradation of native old-growth forests and deforestation may have severe negative consequences on forest functions, such as conservation of biodiversity and provision of goods to rural communities. Regarding to this, reforestation can improve the situation for the conservation of native biodiversity; although negative effects have also been reported (Kanowski et al., 2005; 
Lamb et al., 2005; Carnus et al., 2006; Brockerhoff et al., 2008). There are various factors which may determine the efficiency of plantation on biodiversity in a particular area. For example, it is essential to know more on land use prior to plantation, types of tree species involved, how and for what purpose plantations are being managed (Brockerhoff et al., 2008). Reforestation can accelerate forest succession on a previously deforested site by influencing the light availability, understory microclimate, vegetation structural complexity and development of humus layers during the early years of plantation growth (Parrotta et al., 1997; Parrotta, 1999; Yirdaw, 2001; Carnevale and Montagnini, 2002). However, the role of plantation forestry must not only be confined to biodiversity conservation. People living in developing countries often struggle to meet their basic food, health and fuelwood needs, where these plantations may contribute. Pakistan is a similar example where majority of rural people living in mountainous regions, immensely depend on forest products (Adnan et al., 2006).

Pakistan's forests cover an area of $4.8 \%$ of the country's land (Lubna, 2001). The forest resources are under pressure of deforestation and subsequent land degradation (Ali and Tor, 2004) and a rate of deforestation of $1.5 \%$ per year was indicated (FAO, 2005). Forests in some high diverse regions of northwest Pakistan have been classified as Reserved Forests and Guzara Forests (left for public use) (WWF-P, 2004; Lodhi, 2007). A part of the reserved forest was declared National Park in 1984 (Ayubia National Park, ANP). Forests around ANP are being cut ruthlessly, the impact of which is visible in the form of more open Guzara forests (Aumeeruddy et al., 2004). Moreover, the local community depends on non timber forest products (NTFP's) mainly as medicinal plants that are also being overexploited (Aumeeruddy et al., 2004). Such disturbances may result in dwindling of renewable natural resources, like medicinal plants (Southworth and Tucker, 2001). It has been argued that reforestation of degraded land could serve as land rehabilitation and a substitute to meet the demands of local people for fuelwood, timber and NTFPs, thus protecting the remaining natural forests (Brown and Lugo, 1994; Sedjo, 1999).

World Wide Fund for Nature, Pakistan (WWF-P) initiated reforestation on some degraded Guzara forests near villages around ANP, aiming to build capacities of local people in raising 
up tree nurseries and plantation (Aumeeruddy et al., 2004). It was assumed that reforestation of degraded land positively influences the ground flora, particularly the abundance of medicinal plants. However, only little knowledge is available on the impact of reforestation on non-timber forest products, such as medicinal plants of mountain forests in Pakistan. The objectives of our study were (i) to compare the abundance of medicinal plants between reforested and degraded sites and (ii) to assess the influence of reforestation stand characteristics on abundance of medicinal plants.

\subsection{MATERIAL AND METHODS}

\subsubsection{Study area}

This study has been carried out in the Northwest Frontier Province (NWFP) of Pakistan, which constitutes $40 \%$ of the country's forested area (Lubna, 2001). The forests of the region stretch across the Himalayas, Hindu Kush and Karakurum mountain ranges. ANP with an area of 3,312 ha is amongst the 21 national parks in Pakistan and is situated in the Gallis Forest Division of Abbottabad district, NWFP, between $33^{\circ}-01^{\prime}$ to $34^{\circ}-38^{\prime} \mathrm{N}$ latitude and $73^{\circ}-20^{\prime}$ to $73^{\circ}-30^{\prime} \mathrm{E}$ longitude (Fig. 4.1B). The altitude ranges from 1,220 $\mathrm{m}$ to 2,865 $\mathrm{m}$ with Miranjani, being the highest peak (Hussain, 2003). ANP and its surrounding areas, lie within the reach of the monsoon and the mean annual rainfall, which is $1,500 \mathrm{~mm}$, snowfall $2.5 \mathrm{~m}$ and temperature 12 ${ }^{\circ} \mathrm{C}$, all measured at a nearby weather station (WWF-P, 2004). Soils are often shallow and of loamy texture ones. The natural vegetation in this area is Himalayan moist forest, which is characterized by high plant species diversity (Aumeeruddy et al., 2004). Dominant tree species are Abies pindrow Royel, Cedrus deodara G. Don, Pinus roxburghii Sargent, Pinus wallichiana A.B. Jacks, Quercus incana Roxb and Taxus wallichiana Zacc (Shafiq, 2003). About 50,000 people currently live in 12 villages around ANP. The major ethnic group of the area is Hazaarywall, who speak Hindku and Potohari. Fuelwood consumption of each household in the study area, have been estimated 11,000 kg/year (Hussain, 2003). Large amount of fodder, mainly grasses and herbaceous species are collected by women from May to November each year (Jabeen, 1999; Rabia and Khan, 2004). Annually, 13 tons of fodder, is being used per household (Rabia and Khan, 2004). 


\subsubsection{Study sites and medicinal plants}

Study sites have been selected on the areas included in the reforestation program initiated and supported by WWF-Pakistan (1999-2005) on the degraded lands (Guzara forests) surrounding the two villages "Mallach and Passala" (Fig. 4.1C) located in the surroundings of ANP. Degraded land refers to former closed forest area that has been deforested during the last three or four decades, leaving only a few Pinus wallichiana trees. Land ownership of Guzara forests is similar to communal land (Nafees et al., 2009); however, the management belongs to forest department. During reforestation (about 100 ha) of the degraded land, four native tree species (Robinia pseudo-acacia L., Aesculus indica Colebr, Populus ciliata Wall. ex Royle and Salix tetrasperma Roxb) were planted in mixture at an initial spacing of $1 \mathrm{~m}^{2}$ (WWF-P, 2004). The field work has been carried out from July to October 2008. At that time, these plantations have aged between three to eight years. Data have collected from the reforested and degraded sites, both of which provided an open access to grazing animals (goats and cows) and locals for fodder collection. However, $60 \%$ of the reforested area was protected during the initial planting period. The altitude of the study sites ranged between $2,100 \mathrm{~m}$ and 2,200 $\mathrm{m}$ above sea level, where loamy soils and metamorphic rocks were encountered. Stratified random sampling design has been adopted by separating reforested area and degraded land on a map based on geographical information system (GIS). Five random sample points (five plots) each have been allocated to the two land use types. In order to select random sample point on the map, we used lengths of the coordinates $\mathrm{X}$ axis and $\mathrm{Y}$ axis by applying a specific software (ILWIS, version 3.4). Two random points, one at $\mathrm{X}$ axis and one at $\mathrm{Y}$ axis have been selected and the point of their intersection has taken as sample point. Each sample point has considered as the center of each plot and has located in the field by using GPS, compass and other methods.

Ten medicinal plant species have been selected as target species for this study. Selection criteria has high market value, relatively easily identified in the field and conservation concerns in the area. The selected plants are locally used extensively as traditional medicine (Table 4.1). Bergenia ciliata (Haw) Stermb is used as a tonic and for the cure of various stomach diseases. Bistorta amplexicaulis (D. Don) Green is considered to be blood purifying (according to local traditional practitioners) and is used for curing ulcers. Geranium wallichianum D. Don is mainly 
used for the treatment of backache; Paeonia emodi Wall for back pain and as a tonic; Swertia chirata Buch Ham for stomachache and as a tonic; Gallium aparine L for jaundice; Podophyllum emodi Wall for liver disorders and as a tonic, and Plantago lanceolata L for diarrhea and stomach diseases. Valeriana jatamansi Jones and Viola canescens Wall ex Roxb are the two species with the highest market value for the local people and the adequate treatment of cholera and fever respectively. Both species are shade adapted and mostly occur in association with trees (Adnan et al., 2006; Sher and Khan, 2006). Most of the above-mentioned plants can grow well under partial shady conditions except Plantago lanceolata. The selected species have been considered moderately vulnerable towards extinction except Bergenia ciliate (highly vulnerable) and Plantago lanceolata (less vulnerable) (Sher and Hussain, 2007).

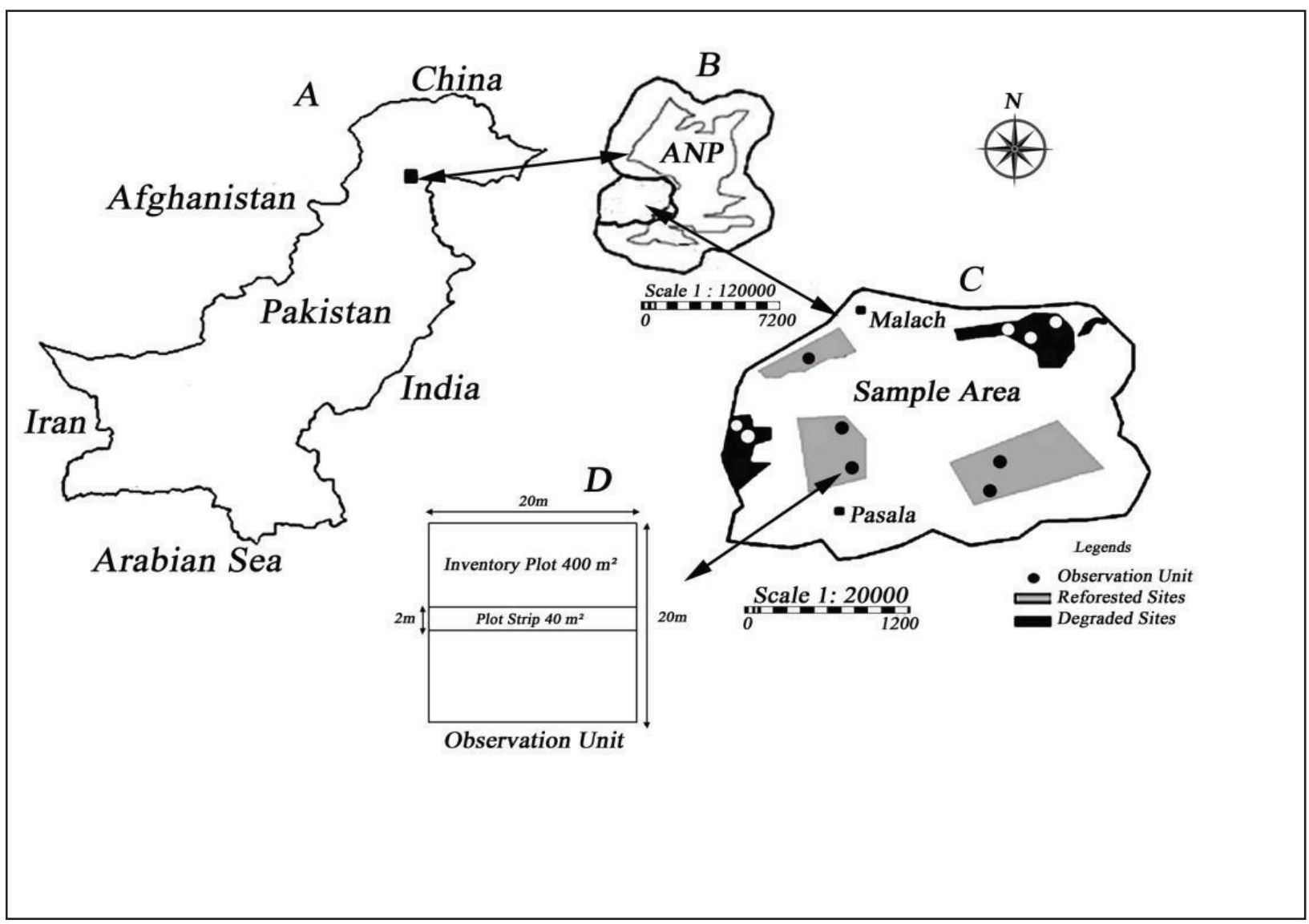

Figure 4.1 Map of the study area and plot design. Pakistan (A). Ayubia National Park's (ANP) boundary (inside boundary) and its surrounding villages and forests (outside boundary) (B). Randomly selected study plots (C) comprising degraded and reforested sites, which belong to the villages (Note: The dark line around the sample area denotes the boundary of the two villages, while the white portion within the sample area indicates households, agricultural area and part of Guzara forest). Plot design (D). 


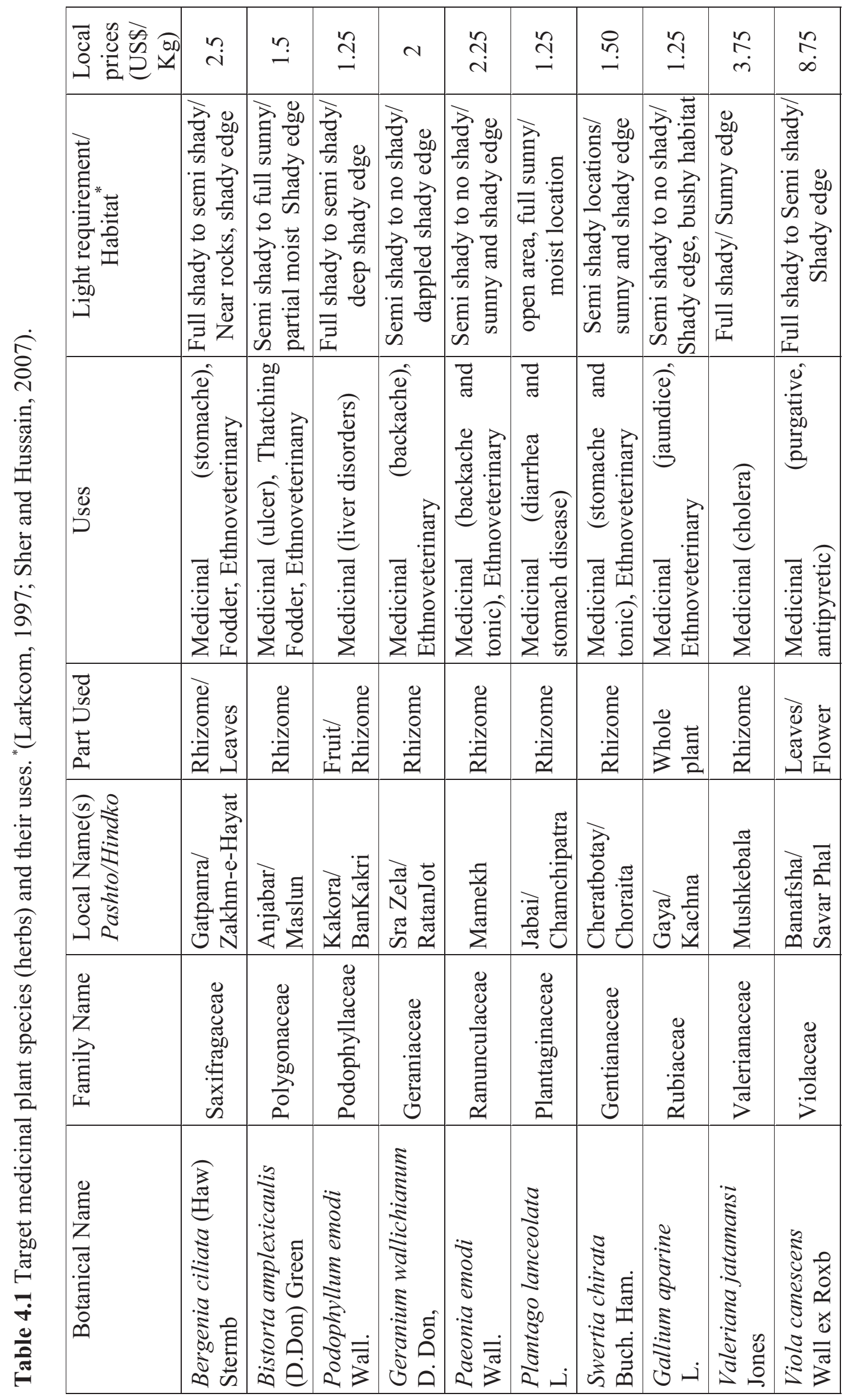

$\infty$ 


\subsubsection{Tree inventory and medicinal plant assessment}

Each plot consists of a tree inventory plot of $20 \mathrm{~m} * 20 \mathrm{~m}=400 \mathrm{~m}^{2}$ and a long horizontal plot strip of $20 \mathrm{~m} * 2 \mathrm{~m}=40 \mathrm{~m}^{2}$ enclosed in each inventory plot for the assessment of medicinal plants (Fig. 4.1D). Plots lay down on the contour line and we have applied slope correction. Recorded tree variables in each inventory plot are diameter at breast height (DBH), basal area, species richness and stem density. Minimum size of $2 \mathrm{~cm}$ dbh of trees has been measured. The Shannon-Wiener diversity index $\mathrm{H}^{\prime}$ (Magurran, 2004) of trees has been calculated for each inventory plot. Hemispherical photographs have been taken vertically along the middle horizontal line at $5 \mathrm{~m}, 10 \mathrm{~m}$ and $15 \mathrm{~m}$ distances per plot with a high resolution digital camera (Minolta Dimage Xt, Japan). The camera had a $185^{\circ}$ fish-eye lens and was placed in a levelling device (Regent Instruments, Canada), which in turn was placed on top of a tripod. Images have been analysed for the forest cover and leaf area index with CanEye 5.0 (INRA, 2007).

Variables of medicinal plants include number of individuals (density), species richness, frequency, biomass and cover. Each plot strip has then been subdivided into 10 quadrates (subplots) of $4 \mathrm{~m}^{2}$ each. Data on percentage cover of each medicinal plant species have been collected through the visual estimation method in proportion (\%) of the total plot strip area, which is covered by species above ground in all parts. The density of each plant species has been recorded by counting the number of individuals. Frequency has been calculated as the percentage of subplots that include species. The estimation of frequency, cover and density have been carried out following the protocol outlined by Curtis and Mc-Intosh (1951). Each variable conferred a single value per plot strip i.e. cover and density, which have been estimated by adding up their respective 10 subplot values, while the frequency is the mean of subplots. Mean biomass of a particular plant species (fresh/dry, above/below, $\mathrm{g} / \mathrm{m}^{2}$ ) per plot strip has been estimated by randomly selecting three plants close to three randomly selected points along the middle line, and then multiplying their average weight (above or below) with the total number of plants of those particular species. The plant species have been dried in shade for 15 to 30 days according to local methods and estimated dry biomass. Similarly, single value per plot strip for species richness and Shannon-Wiener diversity index $\mathrm{H}^{\prime}$, have been derived for targeted medicinal plant species. 


\subsubsection{Statistical analysis}

The Mann-Whitney test has been applied to test differences in mean values $(n=5)$ of various variables of medicinal plants (frequency, density, biomass, cover, Shannon $\mathrm{H}^{\prime}$, and richness) between the two land use types. Tests have been performed at both plot's level (a single value for all medicinal plants per plot strip) and treatment's level (a single value for individual per plot strip) between two sites. Statistical significance has been accepted at $p<0.05$. Detrended Correspondence Analysis (DCA) has been applied to identify variables of forest stand structure (tree $\mathrm{H}^{\prime}$, stem density, tree canopy cover, basal area, leaf area index) probably responsible for increasing the densities of medicinal plant species. As DCA is based on the assumption of normally distributed data; therefore data have been logarithmically transformed to minimize the effect of zeros and bring it to approximate normal distribution. The DCA has been carried out using PC-ORD 5.06 (McCune and Mefford, 1999). Data compilation, Mann-Whitney analysis and Spearman correlation have been carried out by using the programs Excel and SPSS (version 16.0) respectively.

Table 4.2 Tree and stand structural characteristics of reforested and degraded sites. $\mathrm{n}=5$ plots per land use type.

\begin{tabular}{|c|c|c|c|c|c|}
\hline & $\begin{array}{l}\text { Stem Density } \\
\left(\text { no ha }^{-1}\right)\end{array}$ & $\begin{array}{l}\text { Diameter } \\
\quad(\mathrm{cm})\end{array}$ & $\begin{array}{c}\text { Basal Area } \\
\left(\mathrm{m}^{2} \mathrm{ha}^{-1}\right)\end{array}$ & $\begin{array}{c}\text { Tree } \\
\text { Canopy } \\
\text { Cover }(\%)\end{array}$ & $\begin{array}{l}\text { Shannon } \\
\text { Diversity } \\
\left(\text { Index } H^{\prime} \text { ) }\right.\end{array}$ \\
\hline & Mean $\pm \mathrm{SE}$ & $\begin{array}{c}\text { Mean } \pm \\
\text { SE }\end{array}$ & Mean \pm SE & Mean $\pm \mathrm{SE}$ & Mean \pm SE \\
\hline \multicolumn{6}{|l|}{ Reforested sites } \\
\hline Plot Level & $630 \pm 74.68$ & $14 \pm 1.34$ & $7.9 \pm 0.85$ & $36 \pm 8.50$ & $1.2 \pm 0.09$ \\
\hline \multicolumn{6}{|l|}{ Tree Species } \\
\hline Aesculus indica & $140 \pm 65.29$ & $9 \pm 1.79$ & $1.2 \pm 0.58$ & - & - \\
\hline Populus ciliata & $60 \pm 42.48$ & $8 \pm 0.89$ & $0.3 \pm 0.18$ & - & - \\
\hline Robinia pseudo-acacia & $165 \pm 52.77$ & $8 \pm 0.89$ & $1.1 \pm 0.40$ & - & - \\
\hline Salix tetrasperma & $230 \pm 49.19$ & $7 \pm 0.89$ & $1 \pm 0.31$ & - & - \\
\hline Pinus wallichiana & $35 \pm 9.84$ & $40 \pm 8.94$ & $4.4 \pm 2.77$ & - & - \\
\hline \multicolumn{6}{|l|}{ Degraded sites } \\
\hline $\begin{array}{l}\text { Plot Level (Pinus } \\
\text { wallichiana) }\end{array}$ & $50 \pm 11.18$ & $30 \pm 4.47$ & $2.9 \pm 0.85$ & $4 \pm 3.58$ & $0 \pm 0$ \\
\hline
\end{tabular}




\subsection{RESULTS}

\subsubsection{Forest stand structure}

The observed mean tree basal area on reforestation plots $\left(7.9 \mathrm{~m}^{2} \mathrm{ha}^{-1}\right)$ is approximately 2.5 times higher than on degraded plots $\left(2.9 \mathrm{~m}^{2} \mathrm{ha}^{-1}\right)$. Planted trees have contributed $44 \%$ to the total basal area in reforested plots (Table 4.2). Mean tree canopy cover of reforested sites is 9 times higher than those on degraded land. A mean tree $\mathrm{H}^{\prime}$ of 1.2 has been calculated for the reforested area, and tree $\mathrm{H}^{\prime} 0$ for the degraded sites. Mean stem density in the reforested area is about 13 times higher than that of degraded sites.

\subsubsection{Performance of medicinal plants on two land use types}

In total (plot's level), medicinal plants have shown significant differences between the two land use types included in this study (Table 4.3). Mean $\mathrm{H}^{\prime}$ of medicinal plants is twice higher in reforested sites, than in the degraded sites. Density and cover of medicinal plants are 7 times and 5.5 times higher on reforested sites, than on degraded sites respectively.

Table 4.3 Variation of studied medicinal plants on the whole between reforested and degraded sites. ( $\mathrm{n}=5$ plots per land use type). Small letters indicate significant differences at $\mathrm{p}<0.05$, Mann-Whitney test.

\begin{tabular}{lll}
\hline Medicinal Plants Variables & $\begin{array}{l}\text { Reforested Sites } \\
\text { Mean } \pm \text { SE }\end{array}$ & $\begin{array}{l}\text { Degraded Sites } \\
\text { Mean } \pm \mathrm{SE}\end{array}$ \\
\hline Shannon Index $\left(\mathrm{H}^{\prime}\right)$ & $1.45 \pm 0.15^{\mathrm{a}}$ & $0.72 \pm 0.12^{\mathrm{b}}$ \\
Dry weight above ground $\left(\mathrm{g} / \mathrm{m}^{2}\right)$ & $59.3 \pm 31.62^{\mathrm{a}}$ & $6 \pm 3.04^{\mathrm{b}}$ \\
Dry weight below ground $\left(\mathrm{g} / \mathrm{m}^{2}\right)$ & $58.0 \pm 32.51^{\mathrm{a}}$ & $2 \pm 1.12^{\mathrm{b}}$ \\
Density $\left(\mathrm{no} \mathrm{m} \mathrm{m}^{-2)}\right.$ & $9.75 \pm 4.39^{\mathrm{a}}$ & $1.31 \pm 0.35^{\mathrm{b}}$ \\
Cover $\%\left(1 \mathrm{~m}^{2}\right)$ & $22 \pm 5.81^{\mathrm{a}}$ & $4 \pm 1.34^{\mathrm{b}}$ \\
\hline
\end{tabular}


On treatment's level, frequencies and densities of four medicinal plants (Geranium wallichianum, Paeonia emodi, Swertia chirata and Gallium aparine) are significantly higher on reforested sites, than in degraded sites, while the frequency of Plantago lanceolata is significantly lower. Bergenia ciliata, Bistorta amplexicaulis and Valeriana jatamansi, which were absent from degraded sites have been encountered on reforested sites (Figs. 4.2a, 4.2b). The cover of medicinal plant species show significant differences in five species. Gallium aparine exhibits 47-fold higher cover, Swertia chirata 18-fold, Geranium wallichianum 16-fold and Podophyllum emodi five fold higher cover percentage in reforested areas, compared to the degraded land (Fig. 4.2c).

Indicated by the DCA on the reforested stand, the axis-1 (eigenvalue 0.35) of forest stand structural data has been significantly correlated with basal area $r=0.96(p=0.01)$. The second axis (eigenvalue 0.13) has not shown any significant correlation. This implies that tree basal area is the most important variable influencing the abundance of medicinal plants. Densities of Bergenia ciliate and Valeriana jatamansi have strongly been increased with increasing tree basal area, while Bistorta amplexicaulis, Geranium wallichianum, Viola canescens and Paeonia emodi has had less strong relationships, but positive ones. On the other hand, densities of Swertia chirata, Gallium aparine, Plantago lanceolata and Podophyllum emodi have decreased with increasing tree basal area (Fig. 4.3).

\subsection{DISCUSSION}

Previous studies have already suggested that reforestation may be a source of improvement of ground vegetation (Islam et al., 2001; Huy, 2004). It has even been proposed that reforestation may have a catalytic effect on the regeneration of natural forest biodiversity (Parrotta, 1995; Loumeto and Huttel, 1997). In our study, all reforested sites have been found with higher density, diversity, biomass and cover of medicinal plants compared to degraded sites. Studied degraded sites were comparable to those, which have been subject to reforestation three to eight years prior to our field study. One may assume, that reforestation has been the main reason for high abundance of medicinal plants. 


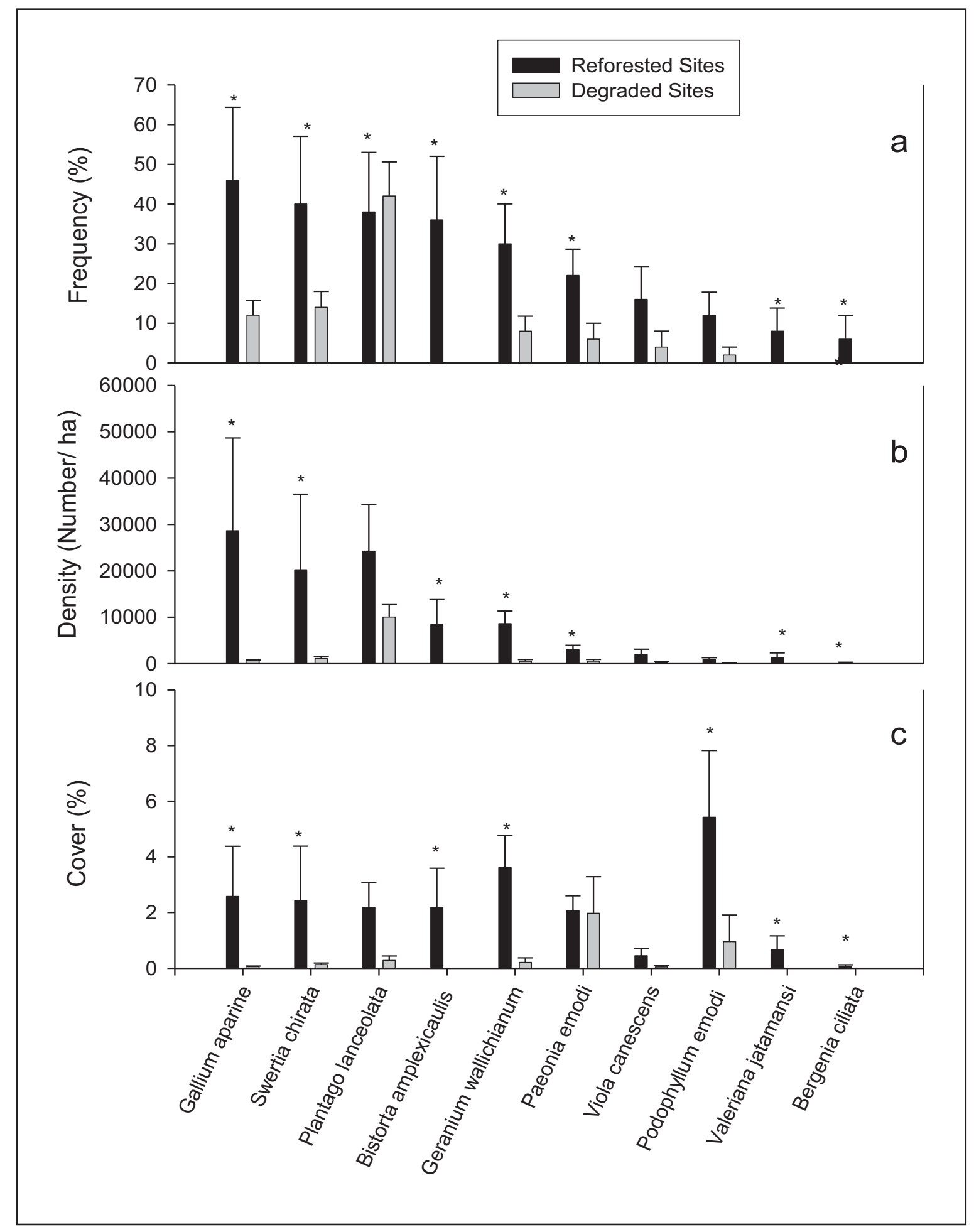

Figure 4.2 Species specific frequencies, densities and cover percentages of studied medicinal plants on reforested and degraded sites. $(n=5$ plots per land use type; $*$ indicates significant differences at $\mathrm{p}<0.05$, Mann-Whitney test). 


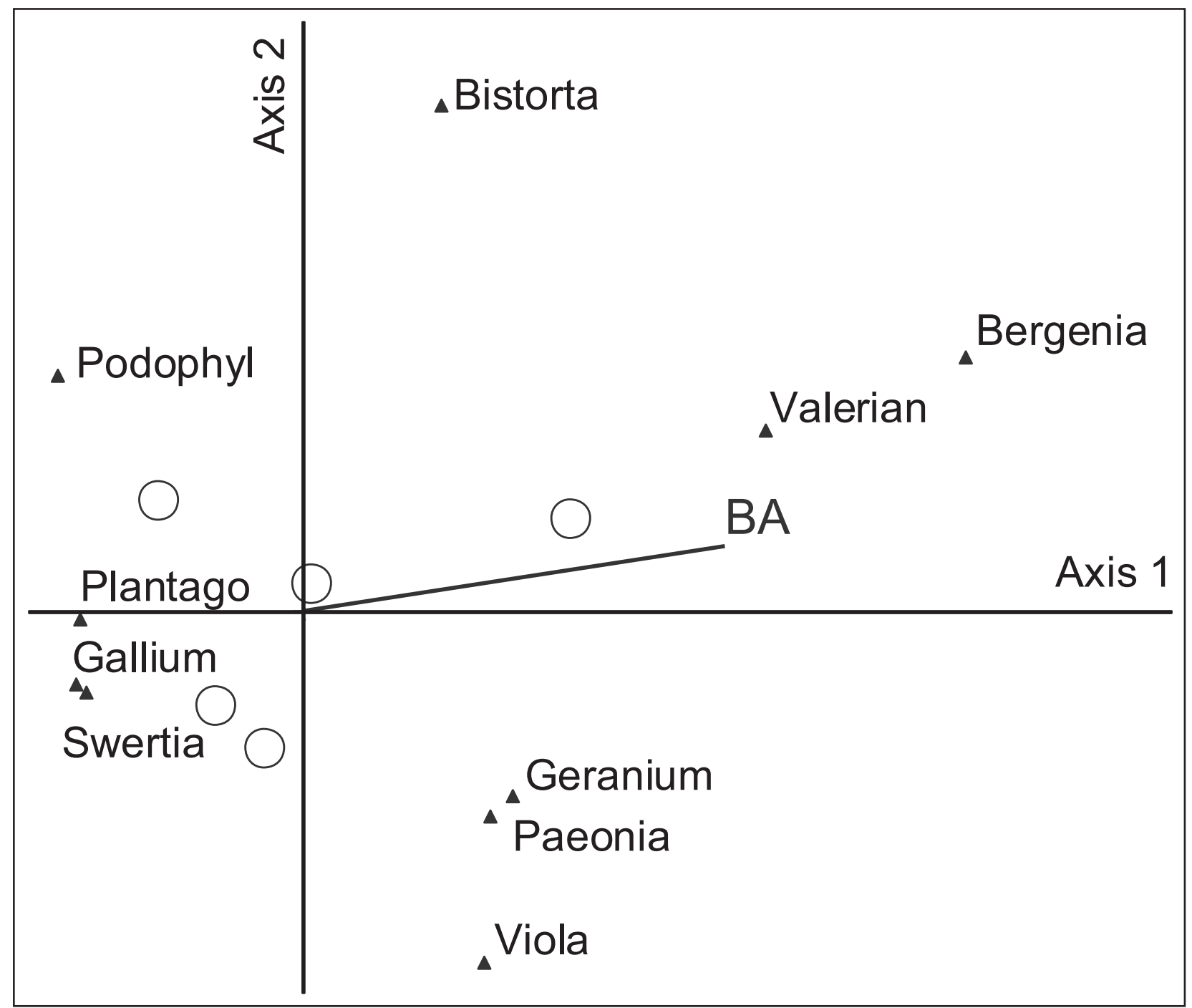

Figure 4.3 Detrended Correspondence Analysis (DCA) for the response of individual medicinal plant densities to tree basal area on reforested sites. Matrix consisted of 5 plots, 10 medicinal plant species and basal area of trees. Axis 1: eigenvalue $=0.35$, explained variance $=48 \%$; Axis 2 : eigenvalue $=0.13$, explained variance $=30 \%$. Correlation threshold: $r^{2}>0.5$. Significant correlations (Pearson) at $\mathrm{p}<0.01$ have only been observed for basal area $(\mathrm{r}=0.96)$ with axis 1 . BA indicates tree basal area and round symbols represent plots. Refer to table 4.1 for complete botanical names of medicinal plants.

Comparison of the individual medicinal plant frequencies at degraded and reforested sites, indicate that there is a relation between frequency and reforestation. The reforested sites have a higher frequency in most of the target species, which can grow well under partial or full shade. 
In the other hand, frequency of Plantago lanceolata has been observed less under reforested areas, which might have been due to their better adaptation to growth conditions in open land. Partial shade adapted plants, such as Gallium aparine, Swertia chirata and Geranium wallichianum have had low densities and high frequencies on degraded sites, which have been observed more on reforested sites. Cover percentage of a particular medicinal plant species has usually been associated with its density. However, we have observed an increase in the cover of Paeonia emodi despite of insignificant differences for its density and frequency between both land use types. The reason could have been the enlargement in surface area of leaves under partial shady conditions of reforested sites.

Within the young reforestation stands of our study, higher tree basal area have resulted in the increased abundance of most medicinal plants including three highly valuable species, such as; Valeriana jatamansi, Bergenia ciliata and Paeonia emodi. On the other hand, low tree basal area has appeared to be in favour of species such as Plantago lanceolata, Swertia chirata and Gallium aparine. Basal area has been described as an approximation of canopy cover and has been found in positive correlation with herb layer vegetation in forest stands (Mitchell and Popovich, 1997). However, even at the studied growth stage of the reforestation stands some of the species have been correlated positively with basal area, while the others have negatively been correlated. According to Balandier et al. (2006), abundant over story (quantified through basal area, stem density, or light availability) can even suppress almost all understory species.

Our results suggest that open land species with high densities have decreased, whereas shade adapted species with low densities, have increased with increasing tree basal area on the reforested sites. We also assume that a high abundance of medicinal plants can be achieved in young tree stands with a certain, balanced basal area, which probably stands for partial shady conditions. Also Hannerz and Hånell (1997) and Nagaike et al. (2003) have mentioned that high abundance of understory species, can be found under young plantations. However, if the reforested stands are used for fire wood collection, tree cutting and replanting, they may result relatively young and open stand, and also could probably provide good conditions for medicinal plant abundance in the long run. 
Perhaps, the most important thing for local people is that the abundance of the most valuable medicinal plant species (Valeriana jatamansi, Bergenia ciliata and Paeonia emodi) is significantly higher on reforested areas, than those on degraded ones. At the time of this study, local collectors could have earned approximately 60 US\$ more per hectare on reforested sites. Thus, reforestation can thereby not only contribute significantly to the habitat restoration in the area, but also to the livelihoods of locals depending on medicinal plants. However, from the rural community perspective, it has been observed that they will not accept any approach unless they are being involved in all development, management and conservation interventions for the sustainability of forest resources, particularly in medicinal plants.

As a conclusion, our study indicates that in mountain areas of northwest Pakistan, young reforestation stands have indeed increased the abundance of most of the studied medicinal plants, comparing to deforested and degraded land. Therefore, we suggest the extension of reforestation to further areas of Guzara forest and other mountainous areas of Pakistan, together with the active involvement of local people in management activities.

\subsection{ACKNOWLEDGMENTS}

This work was supported by the Kohat University of Science and Technology (KUST) under the higher education commission of Pakistan's (HEC) human resource development program (HRD) by providing a grant to Muhammad Adnan. The authors are very thankful to the authorities of KUST and HEC for providing the financial support and thus facilitating the smooth execution of this study. The authors are thankful to the World Wide Fund for Nature Pakistan (Peshawar region) team for their kind assistance during data collection. The authors are also thankful to Mareike Roeder and Steffi Heinrichs for their most valuable support in statistical analysis and discussion. 


\subsection{REFERENCES}

Adnan, S.M., Khan, A.A., Abdul, L.K., Zabta, K.S., 2006. Threats to the sustainability of ethnomedicinal uses in northern Pakistan; a case history of Miandam valley, district Swat, NWFP, Pakistan. Lyonia 11, 91-100.

Ali, J., Tor, A.B., 2004. Fuelwood, timber and deforestation in the Himalayas; the case of Basho valley, Baltistan region, Pakistan. Mountain Research and Development 24, 312-318.

Aumeeruddy, T.Y., Zabta, K.S., Abdullah, A., Khan, A.A., 2004. Ethnobotany and management of fodder and fuelwood at Ayubia National Park, Northwest Frontier Province, Pakistan (People and plants working paper). International plants conservation unit, WWF-UK. www.peopleandplants.org/storage/working-papers/wp13.pdf; accessed on 12 July 2008.

Balandier, P., Collet, C., Miller, J., Reynolds, P., Zedaker, S., 2006. Designing forest vegetation management strategies based on the mechanisms and dynamics of crop tree competition by neighbouring vegetation. Forestry 79, 3-27.

Brockerhoff, E., Jactel, H., Parrotta, J., Quine, C., Sayer, J., 2008. Plantation forests and biodiversity: oxymoron or opportunity? Biodiversity Conservation 17, 925-951.

Brown, S., Lugo, A.E., 1994. Rehabilitation of tropical lands: A key to sustaining development. Restoration Ecology 2, 97-111.

Carnevale, N.J., Montagnini, F., 2002. Facilitating regeneration of secondary forests with the use of mixed and pure plantations of indigenous tree species. Forest Ecology and Management $163,217-227$.

Carnus, J.M., Parrotta, J., Brockerhoff, E., Arbez, M., Jactel, H., Kremer, A., Lamb, D., Hara, K.O., Walters, B., 2006. Planted forests and biodiversity. Forestry 104, 65-77.

Curtis, J.T., Mc-Intosh, R.P., 1951. An upland forest continuum in the Prairie forest boarder region of Wisconsin. Ecology 32, 476-496.

FAO (Food and Agriculture Organization). 2005. State of the world's forests - 2005. Rome, Italy.

Hannerz, M., Hånell, B., 1997. Effects on the flora in Norway spruce forests following clearcutting and shelterwood cutting. Forest Ecology and Management 90, 29-49. 
Hussain, K., 2003. Impact of grazing on infiltration capacity of soil (Report). Peshawar, Pakistan: WWF-P Peshawar office.

Huy, L.Q., 2004. Fast growing species plantations - Myths and Realities and their effect on species diversity (report). Himachal Pradesh, India: Dr. Y.S Parmar University of Horticulture and Forestry.

INRA (French National Institute for Agricultural Research),, 2007. Can Eye software. www.avignon.inra.fr/can eye; accessed on 20 July 2008.

Islam, K.R., Ahmad, M.R., Bhuiyan, M.K., Badruddin, A., 2001. Deforestation effects on vegetative regeneration and soil quality in tropical semi-evergreen degraded and protected forests of Bangladesh. Land Degradation and Development 12, 45-56.

Jabeen, A., 1999. Ethnobotany of fodder species of Ayubia National Park (ANP) Nathiagali; its conservation status and impacts on environment (M.Phil thesis). Islamabad, Pakistan: Quid-I-Azam University.

Kanowski, J., Catterall, C.P., Wardell-Johnson, G.W., 2005. Consequences of broad scale timber plantations for biodiversity in cleared rainforest landscapes of tropical and subtropical Australia. Ecology and Management 208, 359-372.

Lamb, D., Erskine, P., Parrotta, J., 2005. Restoration of degraded tropical forest landscapes. Science $310,1628-1632$.

Larkcom, J., 1997. Plants for a future: edible \& useful plants for a healthier world. Permanent publication, UK. http://www.pfaf.org/index.php\#disclaimer; accessed on 08 September, 2009.

Lodhi, A., 2007. Conservation of Leopards in Ayubia National Park, Pakistan. Master of Science in Wildlife Biology (master thesis), Missoula, USA: University of Montana.

Loumeto, J.J., Huttel, C., 1997. Understory vegetation in fast-growing tree plantations on savannah soils in Congo. Forest Ecology and Management 99, 65-81.

Lubna, H., 2001. Analyzing institutional set-up of forest management in Pakistan, Munich personal RePEc archive. MPRA paper no. 7343. mpra.ub.uni-muenchen.de/7343/; accessed on 14 March 2009.

Magurran, A.E., 2004. Measuring biological diversity. Oxford, United Kingdom: Blackwell science. 
McCune, B., Mefford, M.J., 1999. PC-ORD, Multivariate analysis of ecological data, version 5.01. MjM Software, Gleneden Beach, Oregon, USA.

Mitchell, J.E., Popovich, S.J., 1997. Effectiveness of basal area for estimating canopy cover of Ponderosa pine. Forest Ecology and Management 95, 45-51.

Nafees, M., Hizbullah, K., Mohamad, R.J., 2009. Circulatory land tenure and its social and ecological impacts; A case study of the village of Allahdand Dheri in northern Pakistan. Mountain Research and Development 29, 59-66.

Nagaike, K., Hayashi, A., Abe, M., Arai, N., 2003. Differences in plant species diversity in Larix kaempferi plantations of different ages in central Japan. Forest Ecology and Management $183,177-193$.

Parrotta, J.A., 1995. Influence of overstory composition on understory colonization by native species in plantations on a degraded tropical site. Vegetation Science 6, 627-636.

Parrotta, J.A., Turnbull, J.W., Jones, N., 1997. Catalyzing native forest regeneration on degraded tropical lands. Forest Ecology and Management 99, 1-8.

Parrotta, J.A., 1999. Productivity, nutrient cycling and succession in single- and mixed-species plantations of Casuarina equisetifolia, Eucalyptus robusta and Leucaena leucocephala in Puerto Rico. Forest Ecology and Management 124, 45-77.

Rabia, A., Khan, A.A., 2004. Medicinal plants of Ayubia National Park: prospective and constraints. In: Shinwari ZK, Watanabe T, editors. International Symposium on Medicinal Plants: Linkages Beyond National Boundaries. Proceedings 1. Vol 1. Islamabad, Pakistan: Pakistan Agriculture and Research Council, pp 153-161.

Sedjo, R.A., 1999. The potential of high-yield plantation forestry for meeting timber needs. New Forests 17(1/3), 339-359.

Shafiq, C.M., 2003. Some aspect of bio-ecology of Ayubia National Park Northwest Frontier Province, Pakistan (master thesis). Karachi, Pakistan: University of Karachi.

Sher, H., Khan, Z.D., 2006. Resource utilization for economic development and folk medicine among the tribal people; observation from northern part of Pakistan. Pakistan Journal of Plant Sciences 12, 149-162.

Sher, H., Hussain, K., 2007. Rapid vulnerability assessment of medicinal plants, Nathiagali (Report). Peshawar, Pakistan: WWF-P Peshawar office. 
Southworth, J., Tucker, C., 2001. The influence of accessibility, local institutions, and socioeconomic factors on forest cover change in the mountains of western Honduras. Mountain Research and Development 21, 276-283.

WWF-P (World Wide Fund for Nature - Pakistan)., 2004. People and plants - Pakistan: capacity building in ethnobotany applied to conservation and sustainable use of plant resources (Annual Progress Report 1999-2004). Peshawar, Pakistan: WWF-P Peshawar office.

Yirdaw, E., 2001. Diversity of naturally regenerated native woody species in forest plantations in the Ethiopian highlands. New Forests 22, 159-177. 


\section{Chapter 5}


In the Himalayan region of northwest Pakistan, medicinal plants serve as a source of income and primary healthcare for the majority of rural people (Shinwari 2010). However, structural changes in the native old-growth forests have greatly altered the abundance and diversity of medicinal plants, which has had consequences for the rural communities dependent upon them. In this dissertation, we have studied different forest-use types to see how forest transformation could have changed the abundance of medicinal plants and to see whether forest restoration can serve for the recovery of medicinal plants.

\subsection{Medicinal plants under old-growth forest}

Old-growth forest can play an important role in maintaining the abundance and diversity of understory vegetation. In the Himalayan forests, it has been reported that native undisturbed oldgrowth forests support a higher diversity of ground flora than highly disturbed sites (Bhuyan et al., 2003; Uniyal et al., 2010). The affinity of understory vegetation to old-growth forests has been attributed to several factors, such as the reproductive characteristics of the associated plants and the environmental conditions within the forest type, which include favorable microclimate conditions (e.g. deeply shaded microsites) that are typically less common or absent from various forms of degraded forest (D’Amato, 2009).

The old-growth forest studied for this dissertation had undergone little or no human disturbance and supported the highest number of tree species (15) with the greatest tree basal areas and highest levels of tree canopy cover compared to the other forest-use types studied. The oldgrowth forests also hosted 55 of the 59 studied medicinal plant species (herbs and ferns) found across the forest-use types (Table 5.1). A higher density of medicinal plants was found to associate with higher tree canopy cover (Table 2.4), including the most economically valuable species such as Podophyllum emodi, Valeriana jatamansi and Viola canescens, all of which are also adapted to deep-shade conditions (Larkcom, 1997). The density of such medicinal plant species was found to be higher under old-growth forest in comparison with all other forest-use types. This influence might be due to the natural effect of crown cover on the amount of available light for ground vegetation (Shanley and Luz 2003). A Himalayan endemic and 
endangered species "Aconitum heterophyllum" (Kala, 2005; Beigh et al., 2006) was only found in old-growth forest and was absent in all other studied forest-use types. Thus, old-growth forest can serve as a diversity bank for understory medicinal plants. This also draws attention to the need for the protection of such forests to maintain the diversity of medicinal plants at a regional level and to contribute to international conservation initiatives.

\subsection{Medicinal plants under degraded forests}

In the Himalayan region of Pakistan, the rapid expansion of logging, grazing and agriculture brought about significant changes in the forest composition and structure, which put an increasing pressure on many native medicinal plant species (WWF-P, 2004). Human disturbances sometimes have long lasting impacts on the associated flora, such as local extinctions of certain species where changes in the forest structure persist over longer periods of time (Vellend et al., 2006). There are many other factors that account for change in the abundance of ground vegetation such as variation of a site type in terms of tree canopy, tree basal area, age, temperature, amount of light reaching the forest floor, topography, water requirements, pollen distribution, commensalism, soil pH, and soil nutrients among others (Pitkänen, 2000; Shanley and Luz, 2003).

Four different degraded forests were studied for this dissertation with different levels and degrees of anthropogenic disturbance, which include forest degraded by logging, derived woodland, agroforest and degraded sites. In this study, tree canopy cover, tree basal area, tree species richness, Shannon diversity and stem density were strongly reduced on the degraded forests compared to old-growth forest (Table 5.1). Similarly affected were the richness, density and diversity of medicinal plants (Table 5.1). Such severe declines are most likely due to intensive human related pressures, as have been observed for other Himalayan forests (Bhuyan et al., 2003; Nath et al., 2005). 


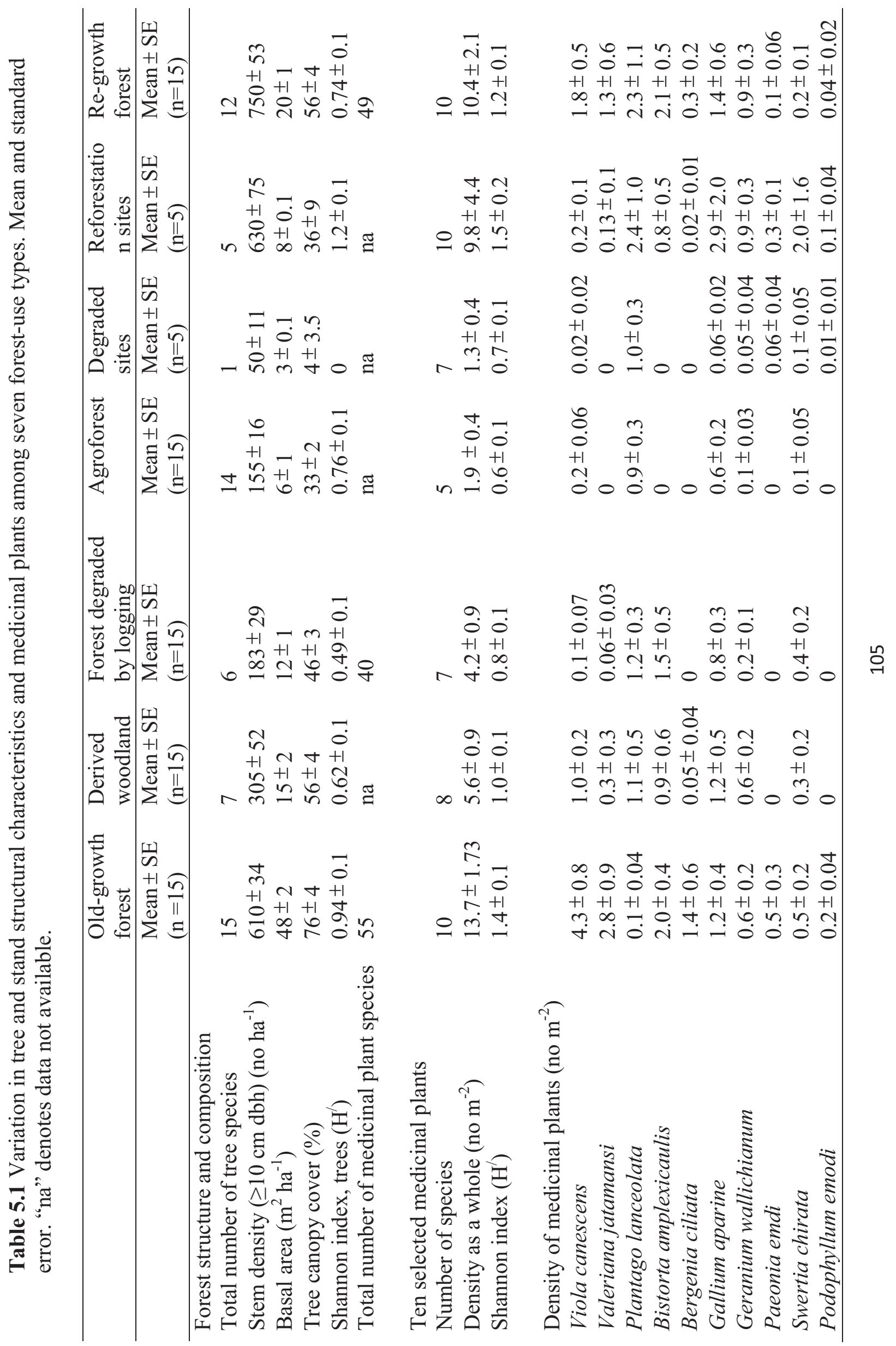


Some of the most valuable species, such as Bergenia ciliata, Paeonia emodi, Podophyllum emodi and Valeriana jatamansi, were absent from most of the studied degraded forest-use types, mostly because of anthropogenic pressures. The low abundance and diversity of medicinal plants in the degraded ecosystems were most likely a reflection of the lower levels of resource availability (e.g. light, nutrients) in the understory layer (D'Amato, 2009). The density of certain medicinal plant species such as Plantago lanceolata was observed to be higher under degraded forests compared to old-growth forest (Table 5.1), which may be due to their better adaptation to growth conditions in open landscapes. Hence, this study confirms that the occurrence and density of certain understory medicinal plants in the degraded forests may depend on factors such as the response of each species to canopy openness and their ability to invade and persist in disturbed habitats including forest transformation into agriculture land.

\subsection{Forest restoration "an opportunity for the recovery of medicinal plants"}

Previous studies have already suggested that forest restoration may be a source of improvement in ground vegetation (Islam et al., 2001; Huy, 2004). It has even been proposed that forest restoration may have a catalytic effect on the regeneration of natural forest biodiversity (Parrotta, 1995; Loumeto and Huttel, 1997). Forest restoration can accelerate forest succession on a previously degraded and deforested site by influencing the light availability, understory microclimate, vegetation structural complexity and development of humus layers during the early years of tree growth (Parrotta et al., 1997; Yirdaw, 2001; Carnevale and Montagnini, 2002). Restoration can improve the situation for the conservation of native biodiversity; although negative effects have also been reported (Kanowski et al., 2005; Lamb et al., 2005).

We have studied two different kinds of forest restoration. Re-growth forest that has been subject to natural native tree regeneration has been observed with higher quantities of tree basal area and tree canopy cover compared to all other forms of degraded forest-use type. Reforestation sites composed of planted, fast-growing tree species were observed to have higher tree basal area and tree canopy cover compared to agroforest and degraded sites (Table 5.1). 


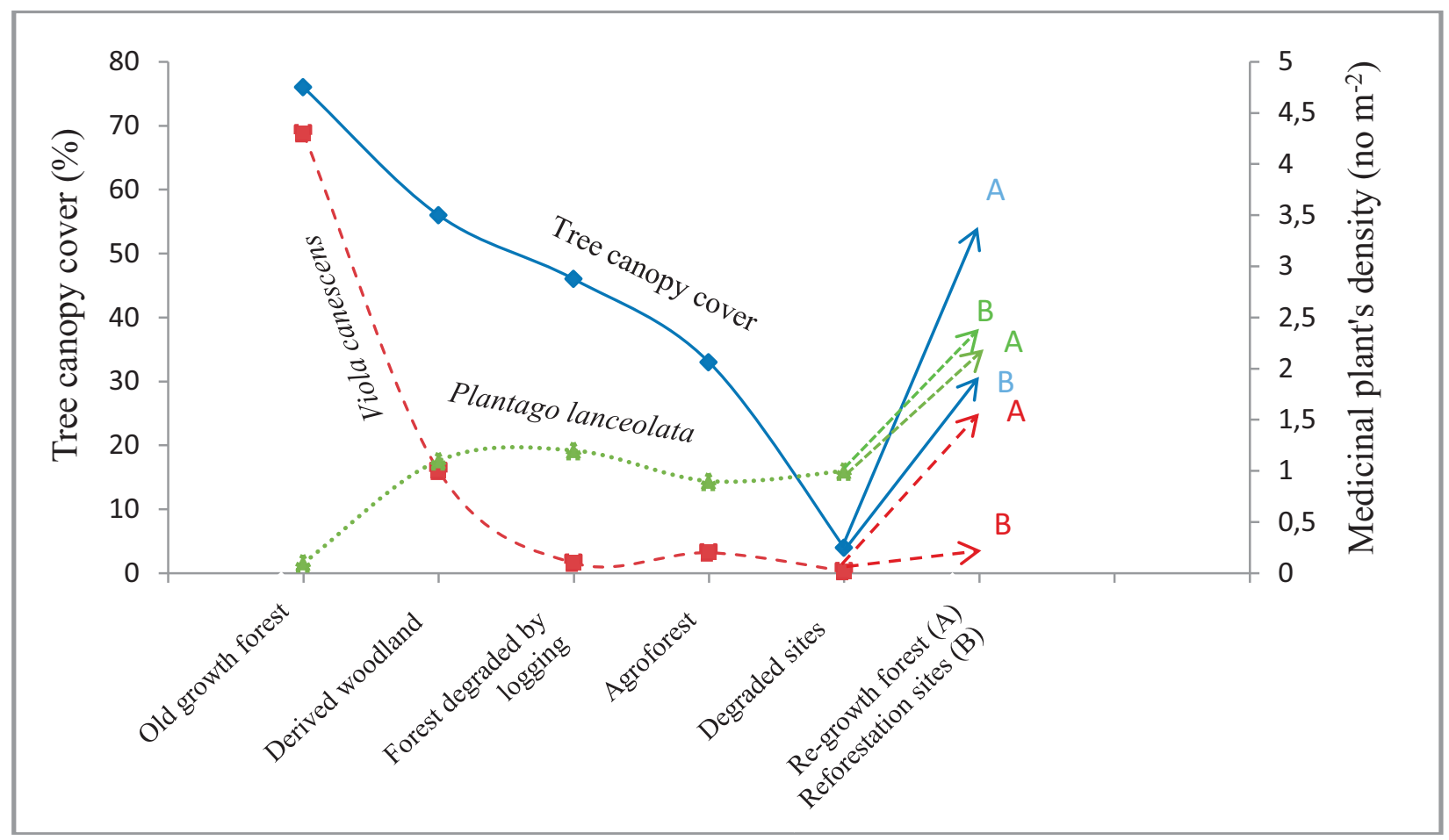

Figure 5.1 A diagram of changes in the tree canopy cover among seven forest-use types and the corresponding changes in the abundance of medicinal plants (Plantago lanceolata and Viola canescens). Tree canopy cover is shown as a solid line, and the corresponding changes in the abundance of two medicinal plant species are shown as two different kinds of dotted line. Trend A represents natural re-growth of native tree species. Trend B represents reforestation sites of planted fast-growing tree species.

A comparison of ten valuable medicinal plants showed that both forest-use types, i.e. re-growth and reforestation sites, contained all ten species. Similarly, both forms of forest restoration were observed to contain higher densities of medicinal plants compared to the studied degraded forestuse types. The Shannon index $\mathrm{H}^{\prime}$ of medicinal plants on reforestation sites was observed to be highest across the forest-use types, which might be due to the highest diversity of trees being observed under this forest-use type. Both the forest-use types supported a comparatively high abundance of medicinal plant species, such as Paeonia emodi and Podophyllum emodi, which were absent from most of the degraded forests (Table 5.1). In Figure 5.1, a decline in tree canopy cover is shown to accompany forest degradation, which is further increased when forest regrowth (A) and reforestation (B) begins to occur. This is concordant with Figure 1.1; however, the comparison in the abundance of medicinal plants between re-growth forest and reforestation sites might depend on species adaptation to different light conditions. The density of Viola 
canescens (shade adapted) was found to be higher under old-growth forest compared to the other degraded forest-use types, while for Plantago lanceolata (sun adapted), it was the opposite. Differences in biodiversity among two different forest restoration types has also been reported by Lamb et al. (2005). For example, the density of Viola canescens was strongly augmented under forest re-growth than in reforestation sites, while the density of Plantago lanceolata was higher in reforestation sites compared to forest re-growth (Fig. 5.1). Hence, shade adapted, commercially valuable medicinal plants can recover strongly under natural forest re-growth conditions, which could represent an opportunity both for ecological restoration and rural livelihood enhancement, and above all, general support for forest expansion in the region.

\subsection{REFERENCES}

Adnan, S.M., Khan, A.A., Abdul, L.K., Zabta, K.S., 2006. Threats to the sustainability of ethnomedicinal uses in northern Pakistan; a case history of Miandam valley, district Swat, NWFP, Pakistan. Lyonia 11, 91-100.

Beigh, S.Y., Nawchoo, I.A., Iqbal, M., 2006. Cultivation and conservation of Aconitum heterophyllum: A critically endangered medicinal herb of the northwest Himalayas. Journal of Herbs, Spices \& Medicinal Plants 11(4), 47-56.

Bhuyan, P., Khan, M.L., Tripathi, R.S., 2003. Tree diversity and population structure in undisturbed and human-impacted stands of tropical wet evergreen forest in Arunachal Pradesh, Eastern Himalayas, India. Biodiversity and Conservation 12, 1753-1773.

Carnevale, N.J., Montagnini, F., 2002. Facilitating regeneration of secondary forests with the use of mixed and pure plantations of indigenous tree species. Forest Ecology and Management $163,217-227$.

D’Amato, A.W., Orwig, D.A., Foster, D.R., 2009. Understory vegetation in old-growth and second-growth Tsuga canadensis forests in western Massachusetts. Forest Ecology and Management 257, 1043-1052.

Huy, L.Q., 2004. Fast growing species plantations - Myths and Realities and their effect on species diversity (report). Himachal Pradesh, India: Dr. Y.S Parmar University of Horticulture and Forestry. 
Islam, K.R., Ahmad, M.R., Bhuiyan, M.K., Badruddin, A., 2001. Deforestation effects on vegetative regeneration and soil quality in tropical semi-evergreen degraded and protected forests of Bangladesh. Land Degradation and Development 12, 45-56.

Kanowski, J., Catterall, C.P., Wardell-Johnson, G.W., 2005. Consequences of broad scale timber plantations for biodiversity in cleared rainforest landscapes of tropical and subtropical Australia. Ecology and Management 208, 359-372.

Lamb, D., Erskine, P., Parrotta, J., 2005. Restoration of degraded tropical forest landscapes. Science 310, 1628-1632.

Larkcom, J., 1997. Plants for future: edible, medicinal and useful plants for healthier world. Permanent publication, UK. http://www.pfaf.org/user/default.aspx; accessed on 10 April, 2011.

Loumeto, J.J., Huttel, C., 1997. Understory vegetation in fast-growing tree plantations on savannah soils in Congo. Forest Ecology and Management 99, 65-81.

Nath, P., Arunachalam, A., Khan, M., Arunachalam, K., Barbhuiya, A., 2005. Vegetation analysis and tree population structure of tropical wet evergreen forests in and around Namdapha National Park, northeast India. Biodiversity and Conservation 14, 2109-2135.

Parrotta, J.A., 1995. Influence of overstory composition on understory colonization by native species in plantations on a degraded tropical site. Vegetation Science 6, 627-636.

Parrotta, J.A., Turnbull, J.W., Jones, N., 1997. Catalyzing native forest regeneration on degraded tropical lands. Forest Ecology and Management 99, 1-8.

Pitkänen, S., 2000. Effect of tree stand and site variables on alpha diversity of ground vegetation in the forests of Northern Karelia. Journal of Environmental Management 58, 289-295.

Shanley, P., Luz, L., 2003. The impacts of forest degradation non medicinal plant use and implications for health care in eastern Amazonia. Bioscience 53, 573-584.

Shinwari, Z.K., 2010. Medicinal plants research in Pakistan. Journal of Medicinal Plants Research 4, 161-176.

Uniyal, P., Pokhriyal, P., Dasgupta, S., Bhatt, D., Todaria, N.P., 2010. Plant diversity in two forest types along the disturbance gradient in Dewalgarh watershed, Garhwal Himalaya. Current Science 98, 7-10. 
Vellend, M., Verheyen, K., Jacquemyn, H., Kolb, A., Van, C.H., Peterken, G., Hermy, M., 2006. Extinction debt of forest plants persists for more than a century following habitat fragmentation. Ecology 87, 542-548.

WWF-P (World Wide Fund for Nature - Pakistan),, 2004. People and plants - Pakistan: capacity building in ethnobotany applied to conservation and sustainable use of plant resources [Annual Progress Report 1999-2004]. WWF-P Peshawar office, Peshawar.

Yirdaw, E., 2001. Diversity of naturally regenerated native woody species in forest plantations in the Ethiopian highlands. New Forests 22, 159-177. 


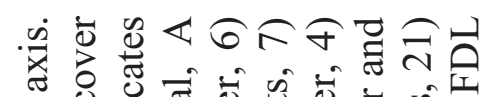
के

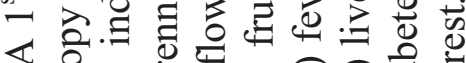

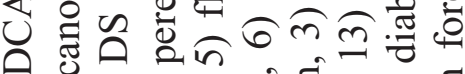

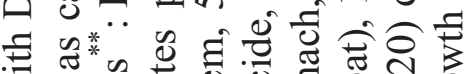

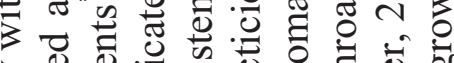

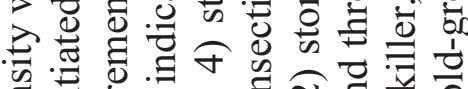

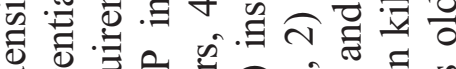
ष

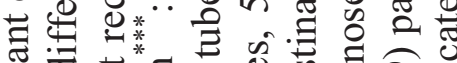

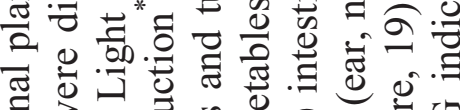

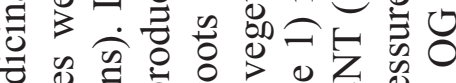

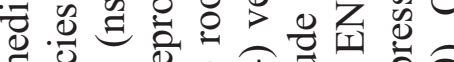

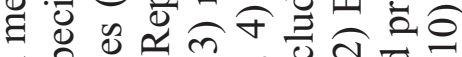

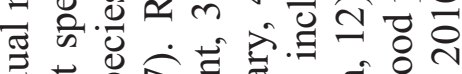
可 등

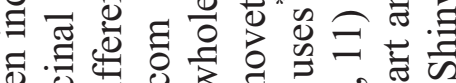
s.

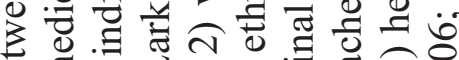

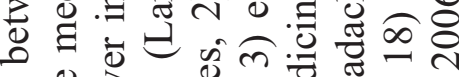

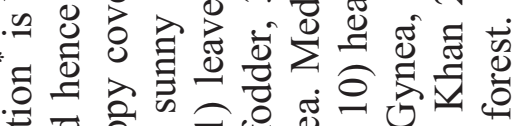
啨

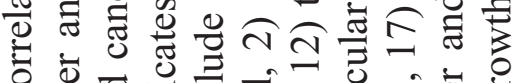

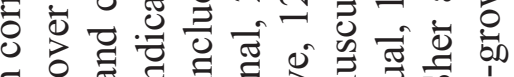

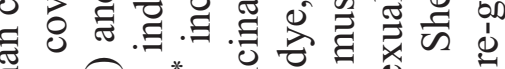

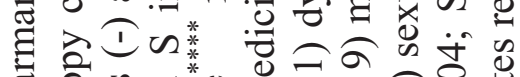
政 no

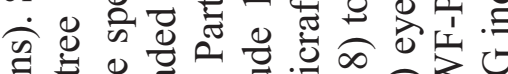
可 t)

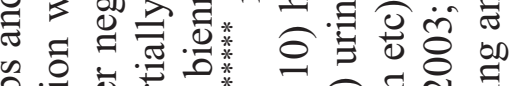

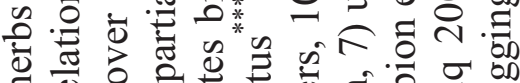

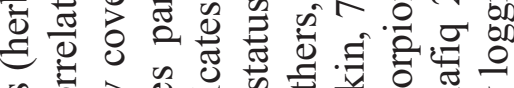

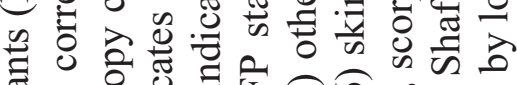
on 可

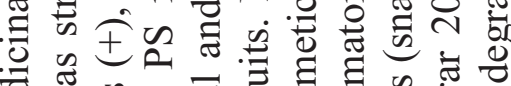

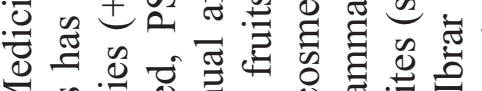

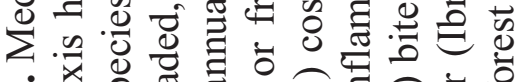

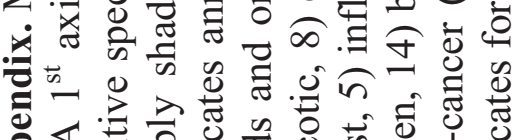

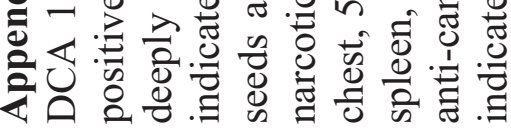

\begin{tabular}{|c|c|c|c|c|c|c|c|c|c|c|c|}
\hline & $\underset{\simeq}{S}$ & $m$ & 0 & & $\Delta$ & 0 & ते & $m m$ & & i & 00 \\
\hline उ్ర & $\overrightarrow{0}$ & ते & $\circ$ & & $\Rightarrow=$ & 0 & ते & $0=$ & a & 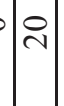 & 00 \\
\hline 总 & O & ते & $\Xi$ & & $\hat{n}$ & & $\cong$ & $\hat{\sim}$ & & ? & $m \mid s$ \\
\hline & $\underset{\simeq}{0}$ & $\begin{array}{l}n \\
0 \\
0\end{array}$ & $\circ$ & & $|\overrightarrow{\mid}|$ & & $\begin{array}{l}\dot{0} \\
\stackrel{0}{0} \\
\end{array}$ & $\overline{0}: \frac{m}{0}$ & & ?ִ & 00 \\
\hline & & $\stackrel{n}{\circ}$ & 0 & & \begin{tabular}{|l|l|} 
\\
0 \\
0
\end{tabular} & & $\mid$ & 0 & & $\left|\begin{array}{|c|}0 \\
0 \\
0 \\
0\end{array}\right|$ & 00 \\
\hline 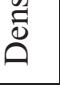 & ठ & $=$ & c & & $\begin{array}{ll}0 \\
0 \\
0 \\
0\end{array}$ & & $\begin{array}{l}0 \\
0 \\
\end{array}$ & $\div$ & & $: \div$ & 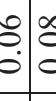 \\
\hline 整 & & 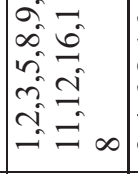 & 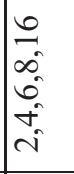 & $\vec{F}$ & & 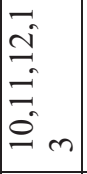 & & & $\mathcal{G}$ & $\Rightarrow$ & -7 \\
\hline
\end{tabular}

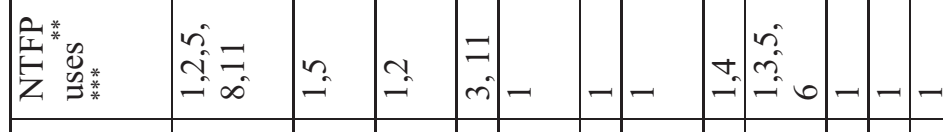

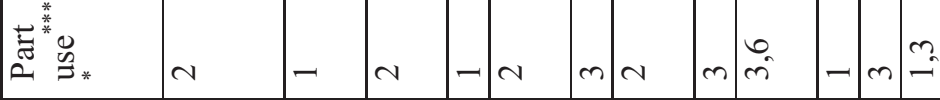

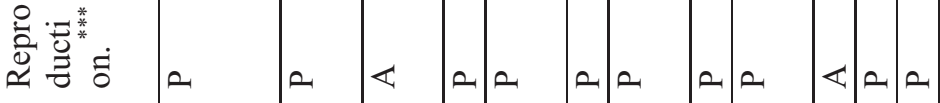

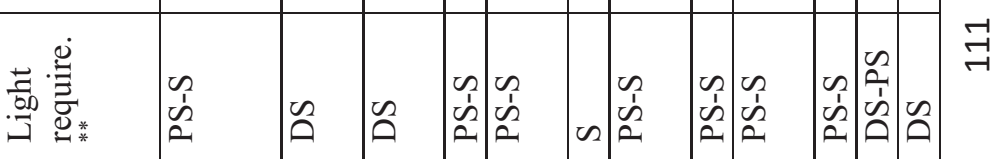

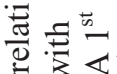

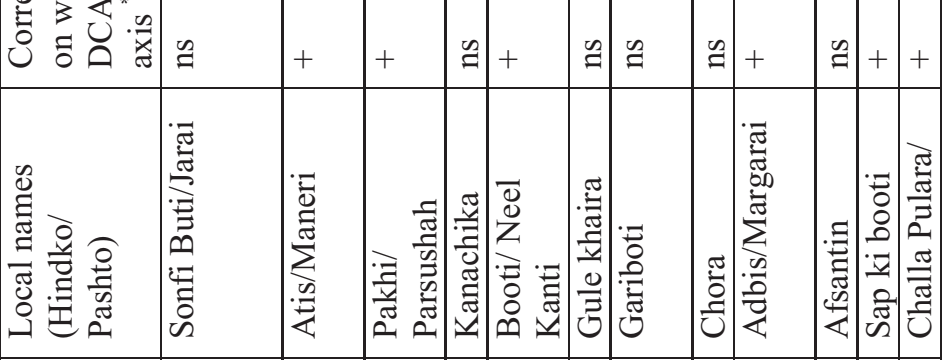

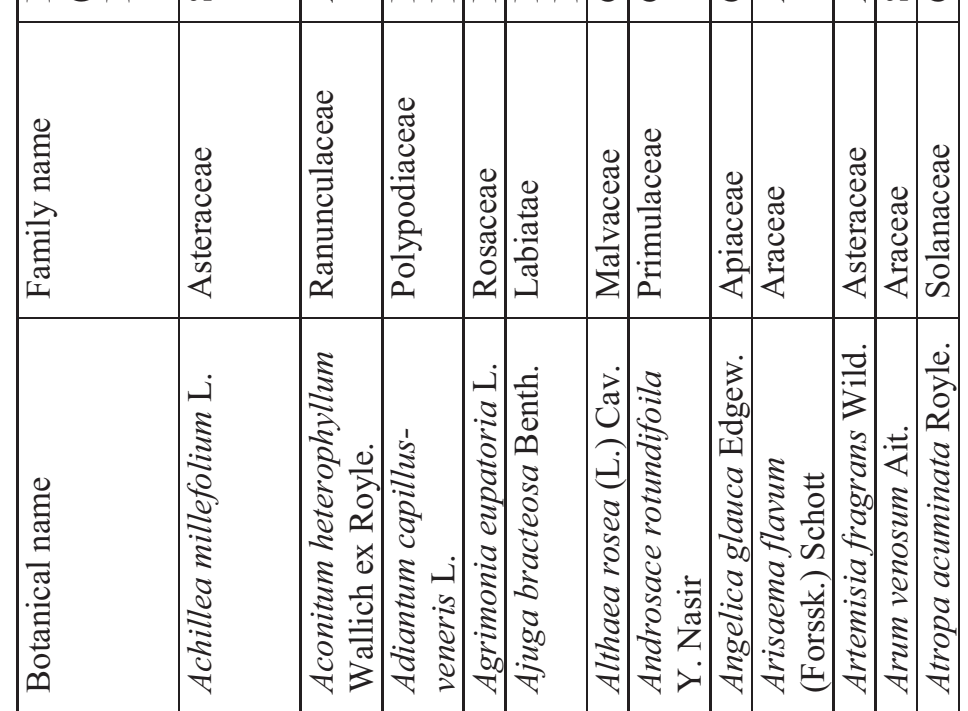




\begin{tabular}{|c|c|c|c|c|c|c|c|c|c|c|c|c|c|c|c|c|c|c|c|c|}
\hline \multirow{3}{*}{ 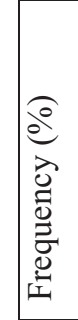 } & צִ & & $\widehat{\imath}$ & $\hat{\infty}$ & $\hat{\lambda}$ & f & $\hat{\sim}$ & $\stackrel{m}{-}$ & 0 & $\grave{\sim}$ & $\stackrel{m}{m}$ & $m$ & $\hat{\sim}$ & $m$ & 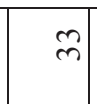 & of & $\widehat{\sim}$ & $\tilde{n}$ & 0 & $\infty$ \\
\hline & 宝 & & 0 & $\widehat{6}$ & ㄱ. & $m$ & ㄱ. & ¿ & 0 & 0 & 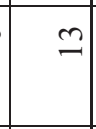 & 9 & নి & 0 & m) & 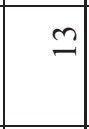 & 8 & $\tilde{n}$ & సิ & $\hat{\sim}$ \\
\hline & ర & & 守 & 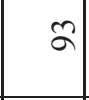 & $\hat{\imath}$ & $m$ & 0 & 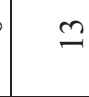 & $\widehat{\sim}$ & ণ & 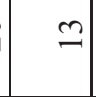 & ㄱ. & $m$ & $\hat{n}$ & ㄱ. & 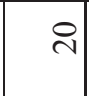 & $m$ & f & શิ & $\hat{6}$ \\
\hline & $\underset{\simeq}{0}$ & & $\begin{array}{l}\text { ?. } \\
0\end{array}$ & $\underset{\sim}{\stackrel{\infty}{i}}$ & 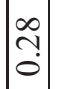 & $\begin{array}{l}0 \\
\vdots \\
0\end{array}$ & $\stackrel{m}{0}$ & ¿̊. & 0 & กิ & $\begin{array}{l}\infty \\
? \\
0\end{array}$ & $\begin{array}{l}0 \\
? \\
0\end{array}$ & $\mid \begin{array}{c}0 \\
0 \\
0\end{array}$ & ஸे & $\frac{1}{0}$ & $\begin{array}{l}0 \\
+ \\
0\end{array}$ & ñ. & $\stackrel{\bullet}{\bullet}$ & 0 & $\stackrel{\circ}{0}$ \\
\hline & 公 & & 0 & $\stackrel{\infty}{\stackrel{\infty}{\leftarrow}}$ & $\because$ & ڤึ. & $\stackrel{n}{0}$ & $\stackrel{n}{\circ}$ & 0 & 0 & $\begin{array}{l}\dot{J} \\
\dot{0}\end{array}$ & 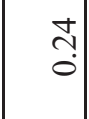 & î. & 0 & 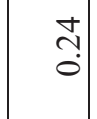 & $\stackrel{?}{\circ}$ & 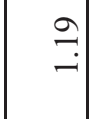 & $\stackrel{\circ}{-}$ & $\begin{array}{l}0 \\
0 \\
0\end{array}$ & $\stackrel{\infty}{\circ}$ \\
\hline & ర & & 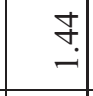 & $\begin{array}{l}n \\
i\end{array}$ & Oे. & $\begin{array}{l}n \\
0 \\
0\end{array}$ & 0 & $\stackrel{0}{\circ}$ & $\begin{array}{l}1 \\
0 \\
0 \\
\end{array}$ & : & $\begin{array}{l}0 \\
0 \\
\end{array}$ & $\stackrel{ \pm}{0}$ & $\frac{1}{0}$ & $\stackrel{\infty}{+}$ & $\begin{array}{l}n \\
0 \\
0\end{array}$ & $\begin{array}{l}t \\
\dot{0} \\
\dot{0}\end{array}$ & $\stackrel{?}{\circ}$ & $\underset{-}{0}$ & $\begin{array}{l}n \\
0 \\
0\end{array}$ & $\begin{array}{l}n \\
\stackrel{0}{0} \\
0\end{array}$ \\
\hline \multicolumn{3}{|c|}{ 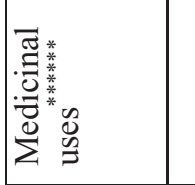 } & 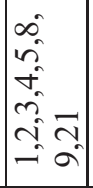 & 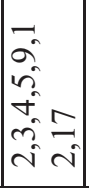 & $=$ & 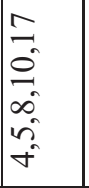 & & $\hat{i}$ & $\cong$ & $\cong$ & $\nabla$ & 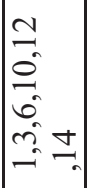 & & $\begin{array}{l}\infty \\
\tilde{n} \\
-\end{array}$ & $\begin{array}{l}0 \\
i \\
-1\end{array}$ & $\stackrel{2}{\approx}$ & $\hat{n}$ & 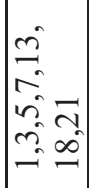 & $\mid \begin{array}{l}\infty \\
- \\
\sim \\
-1 \\
-1\end{array}$ & 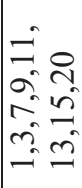 \\
\hline \multicolumn{3}{|c|}{ 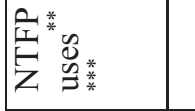 } & $\begin{array}{l}\infty \\
i \\
-\end{array}$ & $\stackrel{3}{-}$ & $\approx$ & $\begin{array}{l}\approx \\
\therefore 0\end{array}$ & $\begin{array}{l}n \\
m \\
n\end{array}$ & - & - & - & $\cong$ & $\approx$ & ले. & $\stackrel{i}{-}$ & - & $\stackrel{\ominus}{-}$ & $\stackrel{f}{i}$ & $\stackrel{1}{-}$ & 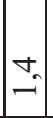 & $\stackrel{i}{-}$ \\
\hline \multicolumn{2}{|c|}{ 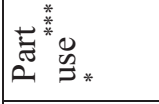 } & & $\stackrel{m}{=}$ & $\stackrel{2}{-}$ & $\mathrm{N}$ & $\stackrel{\sigma_{0}}{-}$ & $\sim$ & 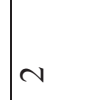 & $\mathrm{N}$ & $\mathrm{N}$ & $\stackrel{\sigma_{0}}{-}$ & $\begin{array}{l}0 \\
n \\
-1\end{array}$ & -1. & - & $\begin{array}{l}0 \\
m\end{array}$ & $\sim$ & $\stackrel{0}{-}$ & N & $m$ & $\stackrel{m}{-}$ \\
\hline \multicolumn{2}{|c|}{ 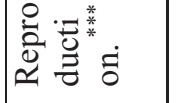 } & & or & a & $a$ & $\varangle$ & a & 2 & 2 & 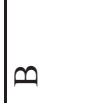 & $m$ & $\ll$ & $a 1$ & a & $\varangle$ & a & a & $\ll$ & $a$ & a \\
\hline \multicolumn{2}{|c|}{ 茍 } & & $\begin{array}{l}\tilde{2} \\
\tilde{n} \\
\tilde{n} \\
\tilde{\rho}\end{array}$ & $\approx$ & $\begin{array}{l}2 \\
\hat{1} \\
\tilde{2} \\
\hat{2}\end{array}$ & is & 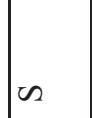 & $\Omega$ & $\tilde{\rho}$ & $\approx$ & us & as & $\left|\begin{array}{l}n \\
\vdots \\
\hat{n} \\
2\end{array}\right|$ & $\tilde{a}$ & as & as & $\begin{array}{l}n \\
n \\
n \\
2\end{array}$ & $\begin{array}{l}n \\
\tilde{n} \\
\tilde{n}\end{array}$ & $\left|\begin{array}{l}n \\
\hat{1} \\
\tilde{2}\end{array}\right|$ & $\begin{array}{l}n \\
\tilde{n} \\
n \\
1\end{array}$ \\
\hline \multicolumn{2}{|c|}{ 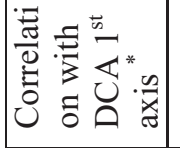 } & & + & $\dddot{a}$ & $\check{a}$ & $\stackrel{2}{q}$ & 1 & 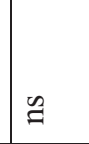 & + & $\stackrel{2}{z}$ & $\stackrel{\text { g }}{\sharp}$ & $\stackrel{\text { a }}{a}$ & $\beth$ & + & $\mathscr{a}$ & $\stackrel{2}{\approx}$ & $\mathscr{a}$ & 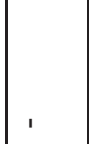 & 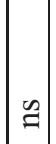 & 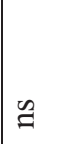 \\
\hline \multicolumn{2}{|c|}{ 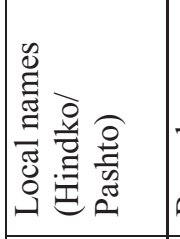 } & & 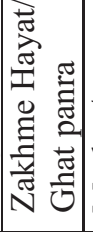 & 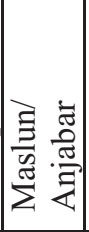 & $\mid \begin{array}{l}\frac{0}{2} \\
\frac{2}{2} \\
\frac{0}{2} \\
\frac{0}{2} \\
2\end{array}$ & 占 & 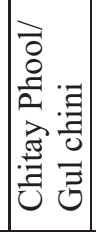 & 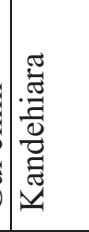 & 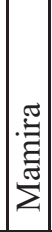 & 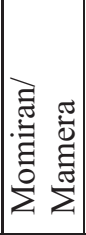 & 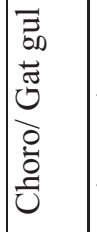 & 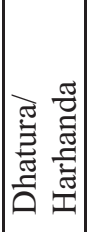 & $:$ & 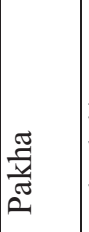 & 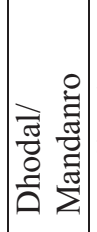 & 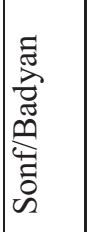 & 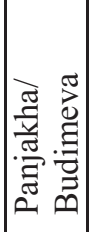 & 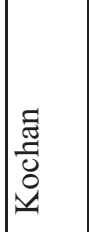 & 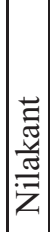 & 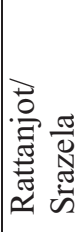 \\
\hline \multicolumn{3}{|l|}{ 芯 } & 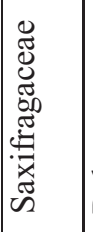 & 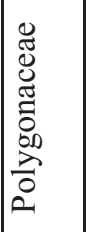 & 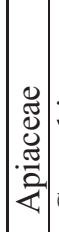 & 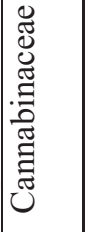 & 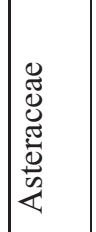 & 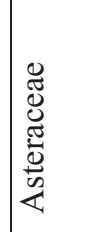 & 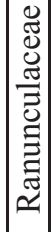 & 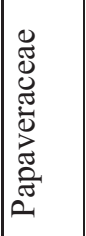 & 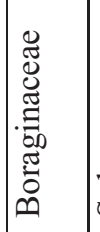 & 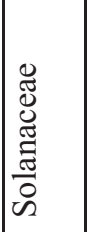 & 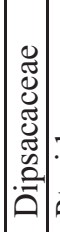 & 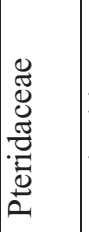 & 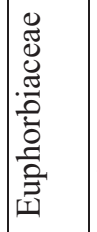 & 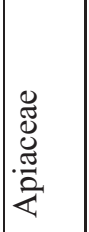 & 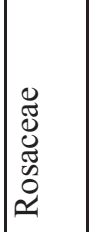 & 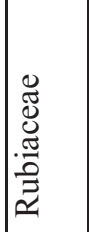 & $\mid$ & 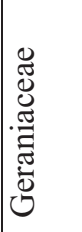 \\
\hline \multicolumn{2}{|l|}{ 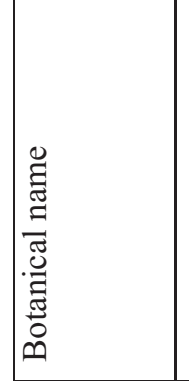 } & & 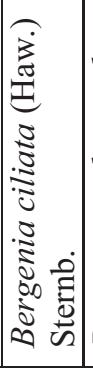 & 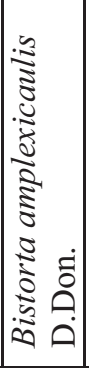 & 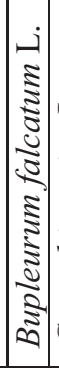 & 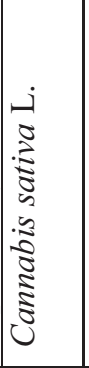 & 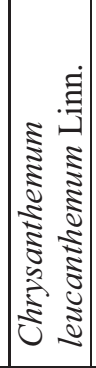 & 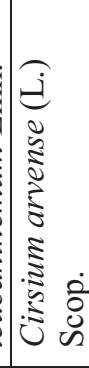 & 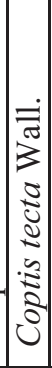 & 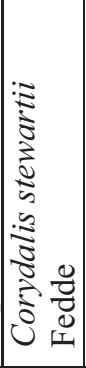 & 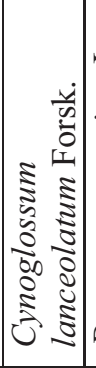 & 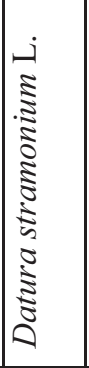 & 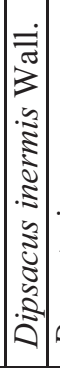 & $\begin{array}{ll}0 \\
0 \\
0 \\
0 \\
\vdots & \vdots \\
0 & 0 \\
0 & 0 \\
0 & 0 \\
0 & 0 \\
0 & 0 \\
0 & 0 \\
0 & 0\end{array}$ & 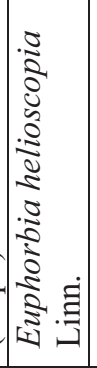 & 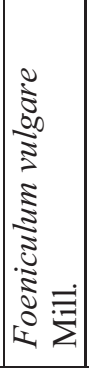 & 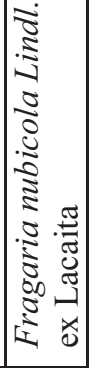 & 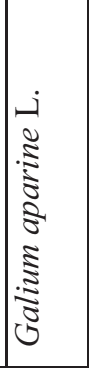 & $\mid$ & 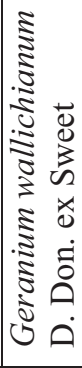 \\
\hline
\end{tabular}




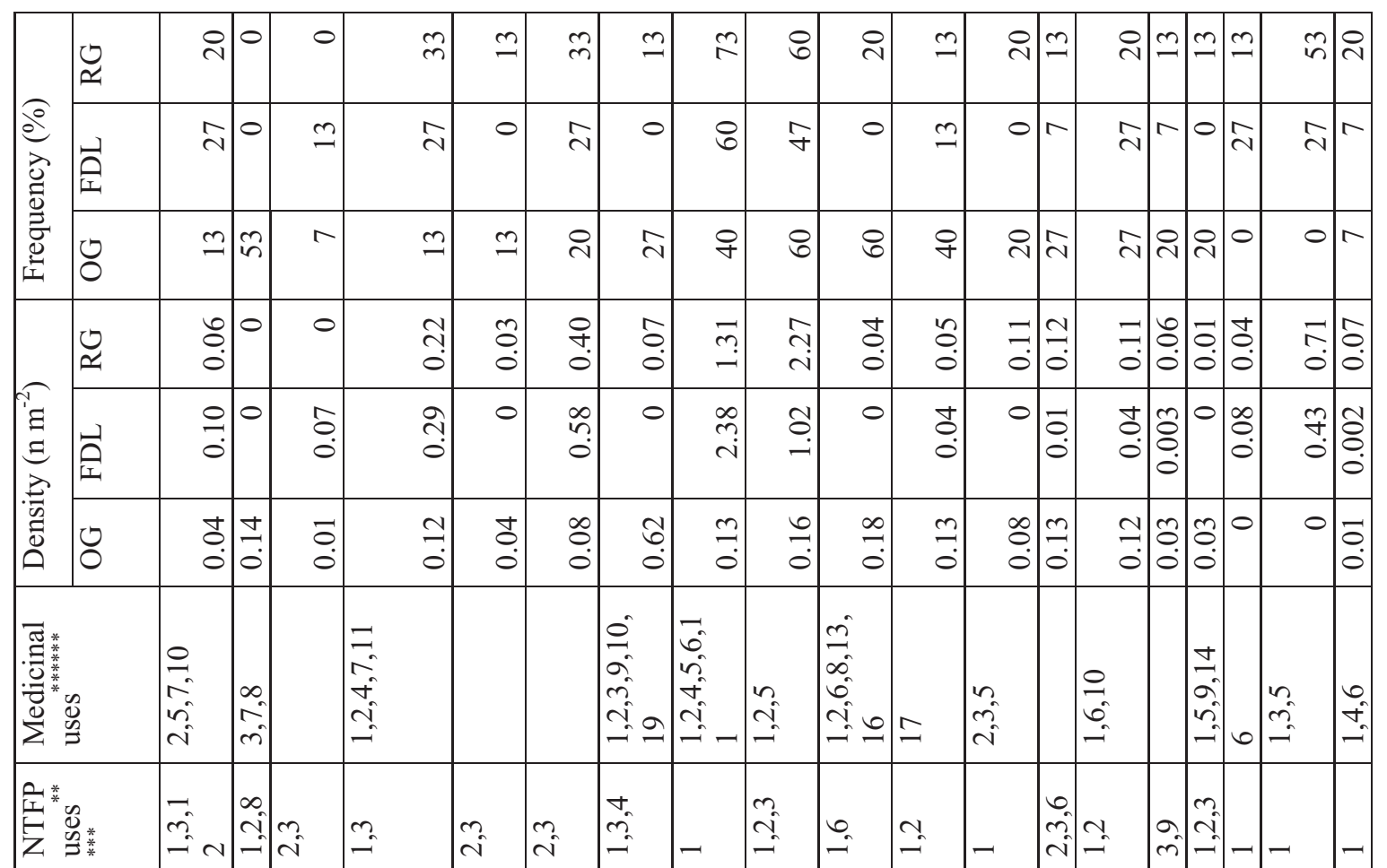

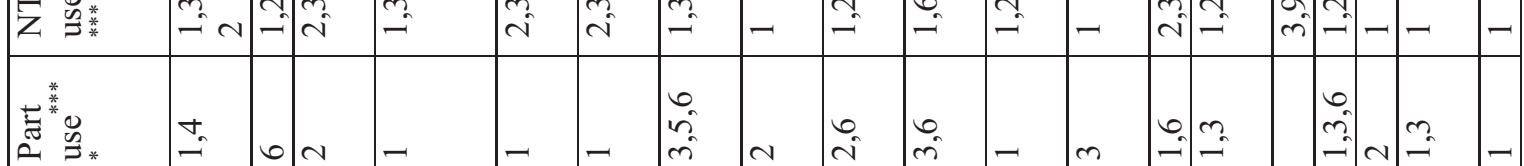

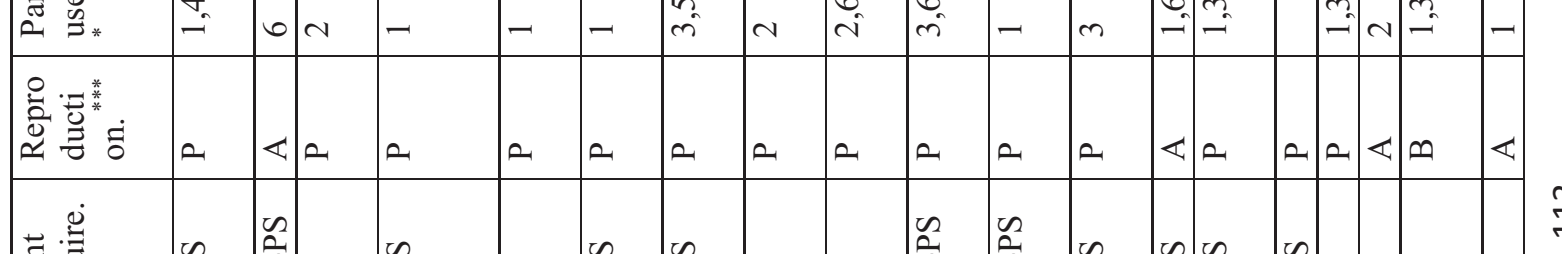

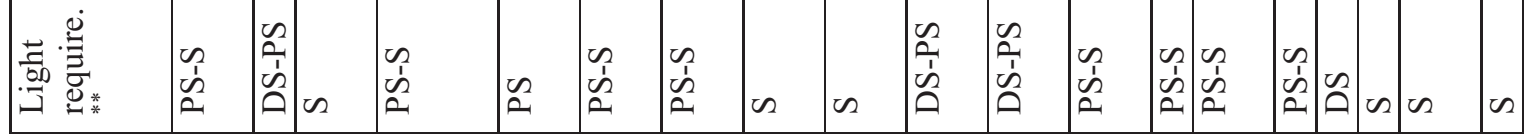

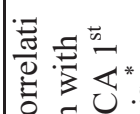

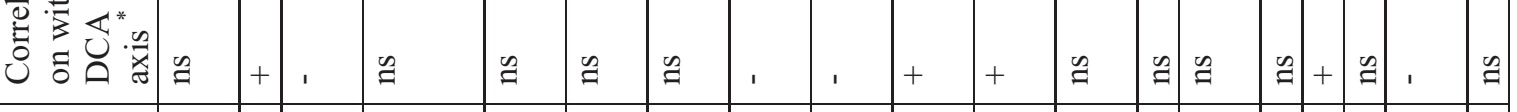

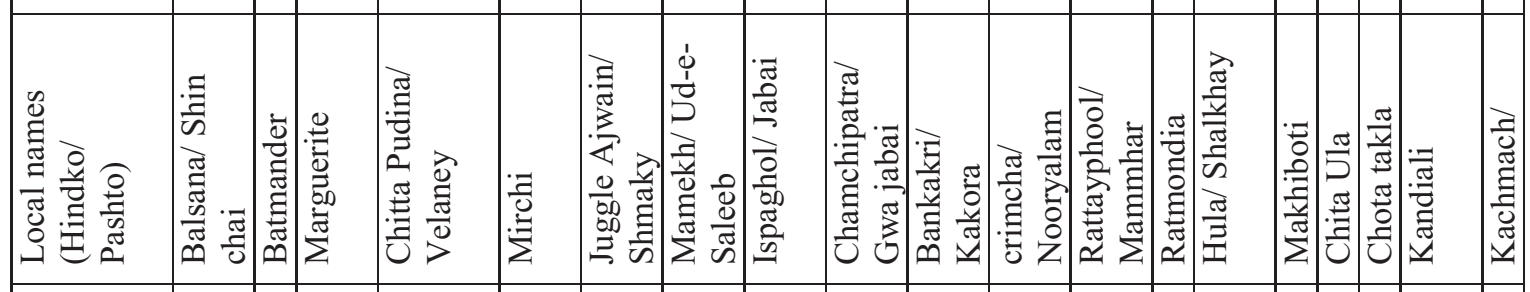

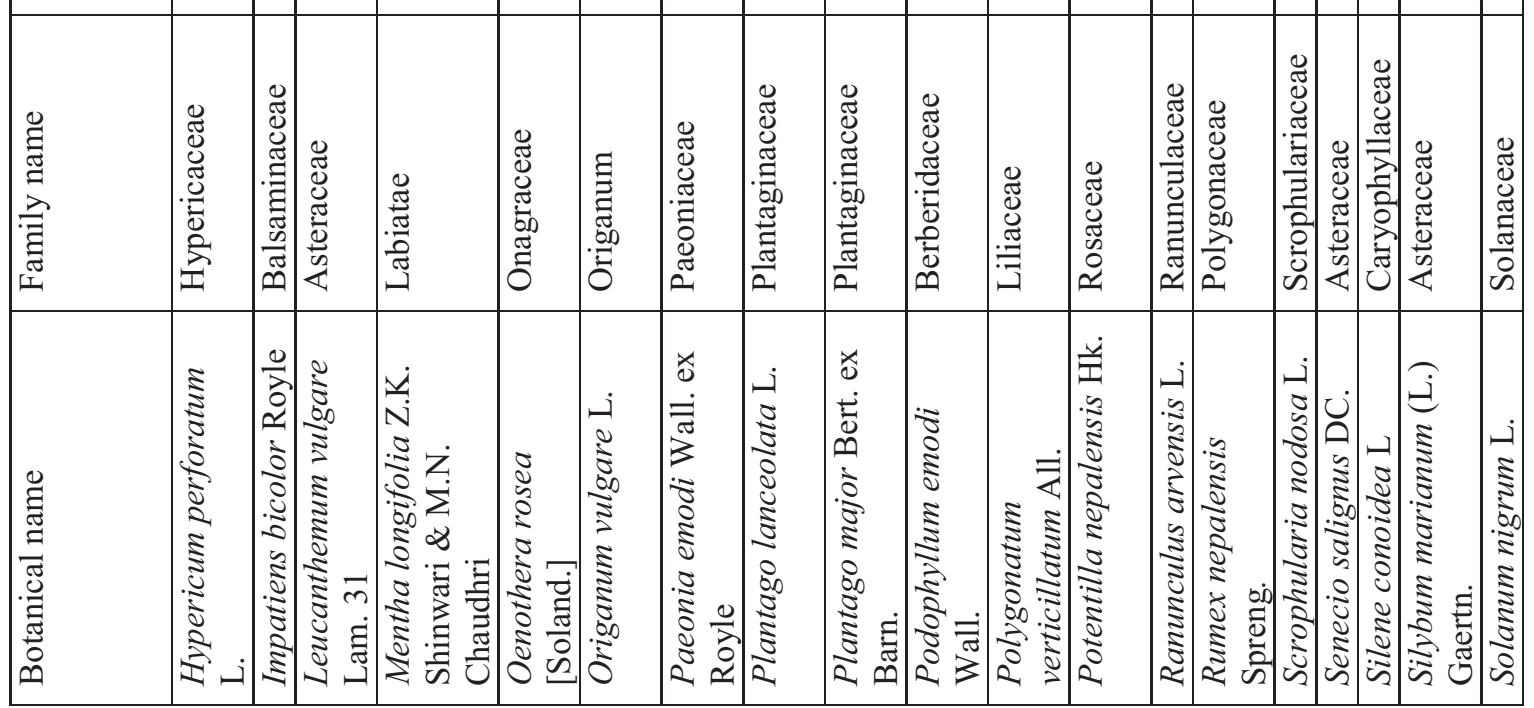




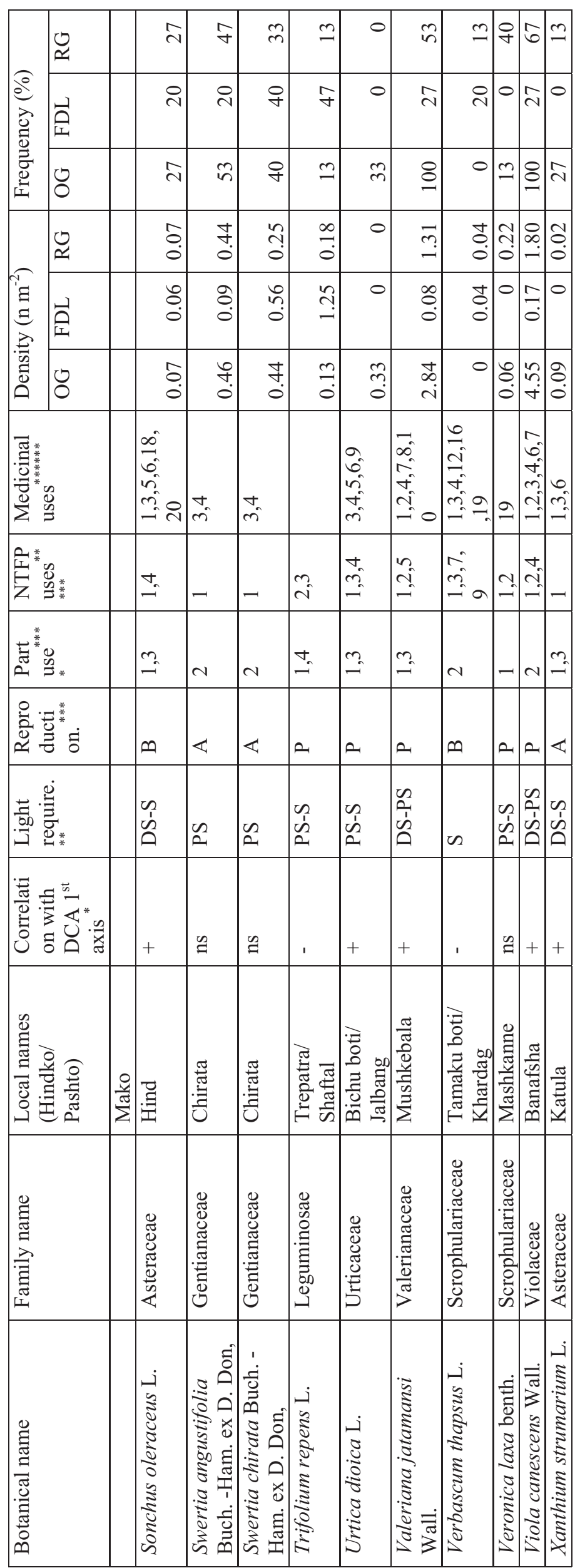




\section{ACKNOWLEDGEMENTS}

First of all I would like to record my gratitude to my supervisor Prof. Dr. Dirk Hölscher for his supervision, advice, and guidance from the very early stage of this research as well as giving me extraordinary experiences though out the work. Above all and the most needed, he provided me unflinching encouragement and support in various ways. His truly scientist intuition has made him as a constant oasis of ideas and passions in science, which exceptionally inspire and enrich my growth as a student, a researcher and a scientist want to be. I am indebted to him more than he knows.

I gratefully acknowledge Prof. Dr. Christoph Kleinn for providing valuable inputs in the methods section of this dissertation. To all my colleagues of the department of Tropical Siviculture: thank you for the very nice working atmosphere. You all gave me very interesting insights into the forests of countries such as Germany, Vietnam, Myanmar, and Philippines.

I am thankful to Kohat University of Science and Technology for providing financial support though Human Resource Development Program of Higher Education Commission of Pakistan. I am thankful to WWF-Pakistan staff members especially Mr. Ibrahim Khan, Mr. Mohammad Waseem, Mr. Kamran Hussain, Ms. Shabana Haider for providing all the required support during my field visits to Pakistan. Special thanks are forwarded to Ms. Sabiha Zaman and Mr. Faiz Ullah Khan for assisting in my field activities. Of course, I thank all my friends who provided me an enjoyable and supportive environment throughout.

Where would I be without my family? My mother Shaheen Tabassum deserves special mention for her inspirable support and prayers, and sincerely raised me with her caring and gentle love. Muhammad Haroon, Saima Naz, Muhammad Fahim and Nosheen Naz, thanks for being supportive and caring siblings.

Finally, I would like to thank everybody who was important to the successful realization of dissertation, as well as expressing my apology that I could not mention personally one by one. 


\section{DECLARATION OF ORIGINALITY AND CERTIFICATE OF OWNERSHIP}

I, Muhammad Adnan, hereby declare that I am the sole author of this dissertation entitled "Diversity and abundance of medicinal plants among different forest-use types of the Pakistani Himalaya". All the references and data sources that were used in this dissertation have been appropriately acknowledged. I furthermore declare that this work has not been submitted elsewhere in any form as part of another dissertation procedure.

Göttingen, November 2011

(Muhammad Adnan) 


\section{CURRICULUM VITAE}

Name:

Date of Birth:

Nationality:

Matrikelnummer:

Present Address (office):

Present Address (Residence):

Phone (office):

Phone (cell):

Email:
Muhammad Adnan

10 April 1975

Pakistan

10830430

Tropical Silviculture and Forest Ecology, Büsgenweg 1, 37077 Göttingen, Germany

Rosenbachweg 12, Room 103, 37075, Göttingen, Germany

+495513912102

+4917683281598

madnan@gwdg.de \& ghurzang@hotmail.com

\section{University education}

- $\mathrm{PhD}$ (Doctor of Phillosophy) from the Faculty of Forest Sciences and Forest Ecology (Department of Tropical Silviculture and Forest Ecology), Georg-August-Univresität Göttingen, Germany from 2008 till present

- Master of Science Honors in Rural Development from NWFP Agriculture University Peshawar, Pakistan in the session 1997-1999

- Bachelor of Science Honors in Agronomy from NWFP Agriculture University Peshawar, Pakistan, in the session 1993-1997

\section{Professional experience}

- Lecturer in Botany, Kohat University of Science and Technology, Pakistan (2006-2008)

- Research Officer, World Wide Fund for Nature Pakistan (2002-2006)

- Field Investigator, Department of Rural Development, NWFP Agriculture University, Peshawar, Pakistan (2000-2001) 


\section{Abroad trainings}

- Two and half months training in Cultivation, Soil preparation, Phytochemistry and Pharmacognossy of economical medicinal plants from Kitasato University, Sagamihara, Japan

- Fifteen days training in green house grown medicinal plants and Phytochemsitry from Showa Pharmaceutical University, Machida, Japan

\section{Home trainings/ training workshops/ seminars organized/ attended}

- Organized three days training workshop on "Off-season Vegetables Cultivation"

- Organized 7 days training workshop on "Off-season Vegetables Cultivation"

- Organized one day training workshop on "Medicinal Plants Collectors"

- Organized three days workshop on "Post Harvest Drying Technique of Medicinal Plants"

- Organized 7 days training on nursery establishment and management of fuel wood plants in the Himalayan Region of Pakistan

- Organized 2 days training on fruit trees plantation in the Himalayan Region of Pakistan

- Organized two days training on fodder cultivation in the Himalayan Region of Pakistan

- Organized a seminar on "Medicinal Plants Conservation for our Better Tomorrow"

- Attended eight days training on "Seed Technology" from Pakistan Forest Institute Peshawar

- Attended eight days training on "Nursery Management and Planting Techniques" from Pakistan Forest Institute Peshawar

- Attended one day National Seminar on "GIS Application to Automated Hydraulic Modeling" at Civil Engineering Department, UET, Peshawar

\section{International workshops/ symposiums/conferences attended}

- Commonwealth Forestry Conference at Edinburg, United Kingdom (2010)

- International workshop on "Land Tenure and Resource Ownership in Pakistan" at Swat, Pakistan

- International workshop on "Curriculum Development in Applied Ethnobotany" at Nathiagali, Pakistan 
- International workshop on "Medicinal and Aromatic Plants in Pakistan" at Islamabad, Pakistan

- International symposium on "Medicinal Plants Linkages Beyond National Boundaries" at Islamabad, Pakistan

\section{Reports}

- Short term training report on the cultivation methods of medicinal plants, and phytochemical analysis and genomic studies of Bupleurum falcatum

- Feasibility for the cultivation of economic medicinal plants on farmlands as substitute to the unsustainable harvest from the Miandam and Sulatanr Forest

- Contribution of the newly introduced vegetables that can meet the fodder requirement of the local community; a case study of villages around Ayubia National Park

- Successes and failures in introducing energy plantation on farm lands in two selected villages for reducing pressure on natural resources of Ayubia National Park

- Assessment and documentation of the "non timber forest flora" as livelihood source for the local community in Swat, NWFP -Pakistan (case study of Miandam Valley)

- Feasibility of community involvement in the sustainable use of medicinal plants in Roringar Valley of District Swat, NWFP

\section{Publications (peer reviewed)}

i. Adnan M., D. Hölscher (2011): Medicinal plants in old-growth, degraded and re-growth forests of NW Pakistan. Forest Ecology and Management 261(11): 2105-2114.

ii. Gillani S. A, Y Fujii, Z. K. Shinwari, M Adnan, A Kikuchi, and K. N. Watanabe (2010): Phytotoxic studies of medicinal plant species of Pakistan. Pakistan journal of Botany 42(2): $987-996$

iii. Adnan M., D. Hölscher (2010). Medicinal Plant Abundance in Degraded and Reforested Sites in Northwest Pakistan. Journal of Mountain Research and Development 30(1): 2532.

iv. Adnan M., J. Hussain, M. T. Shah, Z. K. Shinwari, F. Ullah, A. Bahader, N. Khan, A. L. Khan and T. Watanabe (2010). Proximate and Nutrient Composition of Medicinal Plants 
of Humid and Sub-humid Regions in Northwest Pakistan, Journal of Medicinal Plants Research 4(4): 339-345

\section{Publications (others including conferences, non peer reviewed journals etc)}

v. Adnan, S. M., M. Hamayun and S. Begum and I. Lee (2007): Studies on ethnomedicinal knowledge, market assessment and conservation status of some socioeconomically important medicinal plants of Roringar Valley, District Swat,, J. Phytopharmacotherapy \& Natural Products 1(1):67-72

vi. Adnan, S. M, A. A. Khan, A. Latif. \& Z. K. Shinwari, (2006): Threats to the Sustainability of Ethno-Medicinal Uses in Northern Pakistan; A Case History of Miandam Valley, District Swat, NWFP Province, Pakistan, Journal of Lyonia 11(2)

vii. Begum. S and S. M. Adnan (2006): Role of women in collection, processing and marketing of medicinal plants in Roringar Valley, Swat, Pakistan, Proceedings of the $4^{\text {th }}$ International Congress of Ethnobotany (ICEB 2005), Istanbul, Turkey, 2006, 491-497

viii. Adnan S. M., H. Ahmad., R. Afza., S. K. Hussain and M. Waseem, (2005): Introduction of Off-season Vegetables for Improved Livelihood and Conservation of Plant Resources in Galyat, Proceedings of National Workshop on Conservation Linked to Livelihood Opportunities

ix. Adnan S. M., T. Watanabe., K. Kawaguchi., S. Nagashima., Z. K. Shinwari and T. Yoshikawa, (2004): Phytochemical and Genomic Evaluation of Himalayan Bupleurum Species, International Symposium on Medicinal Plants: Linkages Beyond National Boundaries, PARC-WWFP-SOC, Sep 7-9, 2004, Islamabad

x. Latif, A., S. Begum., M. Adnan., K. Hussian and M. Waseem, (2004): Challenges Faced to Mazri Palm (Nannorhops ritchieana): A Case Study of Jhandey, District MardanPakistan, Ethnobotanical Leaflets Southern Illinois University Carbondale

xi. Adnan, S. M., S. Begum., A. Latif., S. Khan and M. Waseem, (2003): Sustainable Use of Medicinal Plants Through Community Participation In Roringar Valley, Swat, Proceeding of International Workshop on Conservation and Sustainable Uses of Medicinal and Aromatic Plants in Pakistan, WWF-Pakistan

xii. Latif, A., S. Begum, M. Waseem and S. M. Adnan, (2003): Medicinal and Other Economic Plants as Substitute to Forest Logging in Miandam and Sulatanr Valleys Swat, 
Proceeding of International Workshop on Conservation and Sustainable Uses of Medicinal and Aromatic Plants in Pakistan, WWF-Pakistan

xiii. Gilani, S. S., S. M. Adnan., Z. K. Shinwari and Muhammad Shaukat, (2003): Conservation and Management of Medicinal Plants of Roringar Valley, Swat-Pakistan, Proceedings of Workshop on Wise Practices and Experimental Learning in the Conservation and Management of Himalaya Medicinal Plants, $15^{\text {th }}-20^{\text {th }}$ December, 2003, Kathmandu, Nepal

xiv. Khan, S. M. G and S. M. Adnan, (2004): Land Tenure and Resource Ownership (LTRO)-Forest And People With Respect To LTRO in Hazara, Proceedings of Workshop on Land Tenure and Resource Ownership

xv. Qureshi, M. Z., H. N. Khan and S. M. Adnan, (2004): Land Tenure; "Current Situation Issues and Solution", Proceedings of Workshop on Land Tenure and Resource Ownership

xvi. Gilani. S. S and S. M. Adnan, (2002): Azad Darakht-e-Hind, Medicinal Plants: Wonder Drugs of Nature, Natura, Qarterly Magazine of WWF-P, Vol 29, Issue 1 

